\title{
Presidential Administration in a Regime of Separated Powers: An Analysis of Recent American Experience
}

\author{
Jerry L. Mashaw ${ }^{\dagger} \&$ David Berke ${ }^{\ddagger}$
}

This Article examines presidential direction of administrative action in the Obama and early Trump Administrations against the backdrop of ongoing debates concerning: (i) the desirability of and appropriate techniques for presidential control of administration and (ii) the relevance of separated powers when American government is under unified political control. To give this analysis a concrete context, the Article provides in-depth case studies of presidential administration in immigration policy, climate change policy, and executive structuring of the administrative state, under both the Obama and early Trump Administrations. Based on these three case studies, the Article argues that proponents of "presidentialism," who base their support on the supposed effectiveness and democratic legitimacy of muscular presidential administration, have operated with an anemic and poorly specified set of normative criteria. These defects have led supporters to overstate the benefits and understate the risks of presidentialism. The Article further concludes that claims of the functional demise of separated powers, like Mark Twain's death, have been exaggerated. While one cannot understand the functioning of separated powers without understanding the dynamics of party competition, separation of powers has retained functional importance in periods of both unified and divided government notwithstanding the emergence of the current era of hyper-partisanship.

Introduction.

I. Constitutional Preliminaries.

II. Theories of Presidential Administration: Presidentialism vs. Pluralism....554

III. Separation of Powers vs. Separation of Parties ......................................559

IV. Case Studies in Presidential Administration .........................................562

A. Immigration Policy................................................................563

1. Obama: DACA \& DAPA ….................................................563

2. Trump: The Travel Ban, DACA Retention \& the Enforcement

$\dagger \quad$ Sterling Professor of Law Emeritus \& Professorial Lecturer, Yale Law School.

$\ddagger \quad$ J.D. 2017, Yale Law School. 
Boom .568

3. Preliminary Thoughts on Immigration Presidentialism............576

B. Climate Change .....................................................................5 579

1. Obama: The CPP \& the Paris Agreement ................................579

2. Trump: De-Decarbonization....................................................584

3. Climate Policy Prospects.........................................................587

C. The Construction (and Deconstruction) of the Administrative State

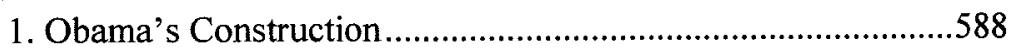

2. Trump's Deconstruction............................................................597

3. Some Preliminary Assessments...............................................65

Conclusion. .607

Introduction

This Article uses recent history to reconsider two longstanding debates in public law and administration. Specifically, this Article examines presidential direction of administrative action in the Obama and early Trump Administrations against the backdrop of ongoing debates concerning: (i) the desirability of and appropriate techniques for presidential control of administration and (ii) the relevance of separated powers when American government is under unified political control. These issues have a history stretching back to the Republic's founding, but retain contemporary relevance.

Both President Obama and President Trump have wielded presidential authority powerfully to shape administrative policy. Moreover, the periods of the Obama Administration and the early Trump presidency provide an opportunity to observe the differential effects of separation of powers-with and without what some have termed "separation of parties" - $\ldots$ on presidential administration in the American system. While the Obama administration mostly operated in the context of deeply divided political institutions, President Trump began with a unified government.

To keep the scope of analysis reasonably manageable, our discussion is limited to three arenas of recent presidential action: immigration policy, environmental regulation related to climate change, and the structure of the administrative state. To say that Presidents Obama and Trump have divergent views on these matters is surely an understatement. Hence, a look at these three topics casts special light on the extent and limits of presidential administration and particularly the durability of presidential policymaking.

Before undertaking our case studies in Part IV, we sketch some important constitutional background in Part I. In Parts II and III, we situate our case studies

1. See Daryl J. Levinson \& Richard H. Pildes, Separation of Parties, Not Powers, 119 HARV. L. REV. 2312 (2006). 
in the context of two broader, ongoing theoretical debates. One is a more normative debate, described in Part III, about the legality and desirability of "presidential administration" or "presidentialism," meaning roughly, muscular presidential direction and control of administrative policy. The other is a more descriptive debate, described in Part III, about the relative influence of basic governmental structure-particularly the relative importance of, on the one hand, an institutionally unified or an institutionally separated system of powers and, on the other, partisan political alignments across government, irrespective of institutional structure. Put more concretely, this second debate is about whether separation of powers matters when the same political party controls both Congress and the presidency. These two debates are connected. The functioning of separated powers informs both the possible and desirable scope of presidential administration.

In general, this study finds in both administrations bold attempts to accrete executive power; presidential administration insinuating itself more and more into areas where proponents of presidentialism have cautioned against aggressive use of presidential directive authority; and the rise of organizational techniques, like policy czars and "shadow cabinets," that institutionalize presidential control in the absence of specific presidential directions. Our case studies also suggest a judicial anxiety with broadening presidential exercises of domestic authority. But recent judicial opinions cabining aspects of that authority have, in our view, sometimes employed questionable reasoning from the perspective of standard administrative law doctrine and may not endure.

We also see a general lack of durability for presidential policy actions across these two Administrations. Indeed, the speed with which presidential administration in the Obama era has been undone by the Trump administration is impressive. To the extent that Obama-era administrative policies have proven even mildly durable, it has been due to political rather than legal constraints or the amount of legal process that initially went into those policies. The rise of administrative governance, combined with muscular presidentialism, can produce dramatic, but perhaps ephemeral, shifts in public policy in the face of congressional inertia and the durability of the statutory bases for administrative action.

Pluralist skepticism of presidential authority has, in some respects, had certain of its concerns vindicated, but presidentialism retains normative attractiveness. Assembly government in tension with executive government is what our system is meant to produce. Over the course of American history, the ascendency of one over the other has shifted many times. The challenge is to moderate the shortcomings of each, when ascendant. The pushback of the nonascendant mode is a means to achieve that moderation, which is why we also consider separation of powers in unified government. And while one certainly cannot comprehend the function of American government without the "separation of parties" perspective discussed below, we still see a real and important role for institutional separation of powers, broadly understood to 
include, in addition to congressional-presidential competition, both judicial defense of congressional policies embodied in statutes and the role of the career bureaucracy in shaping administration.

\section{Constitutional Preliminaries}

The ongoing debate concerning presidential power in the American system persists because the Constitution and administrative law doctrine are startlingly vague about the structure of administrative power and the President's role in it. As one of us has argued elsewhere, there is a hole in the American Constitution where administration might have been. ${ }^{2}$ The Constitution anticipates but fails to create any administrative institutions and divides the creation and control of administration between Congress and the President. Article II gives the President the authority to appoint the heads of "Departments," whatever those are, but leaves the designation of appointive power for all other officials to Congress. ${ }^{3}$ And the President's appointments require Senate approval. ${ }^{4}$ The Constitution says nothing about removal of an official, save for the awkward and cumbersome process of impeachment. ${ }^{5}$

The general contours of executive power, as prescribed by the Constitution, also remain ambiguous. The President must "take Care that the Laws be faithfully executed," but the only power explicitly conferred on the President to carry out that responsibility is the power to require written reports from the heads of departments. ${ }^{7}$ Meanwhile, Article I of the Constitution provides congressional powers that are understood to be broad. ${ }^{8}$ These Delphic provisions concerning political control of administration have been left to be elaborated by practice, convention, and judicial construction.

That last source, Supreme Court doctrine, is sparse and often vague or contradictory. Most of the relevant doctrine involves appointments and removals. ${ }^{9}$ By convention, the appointing official is considered to have the removal power unless otherwise specified by statute. Congress cannot insert itself into appointment or removal, save by exercising the Senate's power of advice and consent to presidential appointments; ${ }^{10}$ providing for the appointment of officials other than department heads by the President, a department head, or the courts; ${ }^{11}$ and by impeachment. Congress may also, at least in certain

2. Jerry L. Mashaw, Creating the Administrative Constitution: The lost ONE HUNDRED YEARS OF AMERICAN ADMINISTRATIVE LAW 10 (2012).

3. U.S. CONST. art. II, $\S 2$, cl. 2.

4. $I d$.

5. $I d$. art. II, $\S 4$.

6. Id. art. II, § 3 .

7. Id. art. II, $\S 2$.

8. See id. art. I, § 8; McCulloch v. Maryland, 17 U.S. (4 Wheat.) 316, 421 (1819).

9. E.g., Buckley v. Valeo, 424 U.S. 1, 124-37 (1976).

10. Bowsher v. Synar, 478 U.S. 714 (1986).

11. U.S. CONST. art. $2, \S 2$. 
circumstances, regulate the qualifications for appointment of particular officers and require that their removal be only for cause. ${ }^{12}$

There is, however, some limit to congressional authority to condition presidential removal authority on cause, under the vague standard that Congress may not "unduly trammel" on executive authority. ${ }^{13}$ That standard was enunciated in a case that permitted for cause removal with respect to a consequential presidential power: criminal prosecution of administration officials. That same standard apparently served to invalidate a so-called "double for cause" provision, where one executive official is subject to for-cause removal solely by a superior, whose removal by the President is similarly restricted. ${ }^{14}$ Yet, as the dissenting justices in that case pointed out, "double for cause" would have no practical impact on presidential authority. ${ }^{15}$ In terms of meaningful constraints on the President's removal authority, one might think these results should be reversed.

Beyond appointments and removals, Supreme Court doctrine is mostly silent concerning a vast array of potential presidential actions designed to shape administrative policy. Here, we are largely in the arena of practice and convention-practices and conventions that are hardly uniform across policy domains or constitutional history.

This dearth of definitive constitutional doctrine sets the stage for the continuing debates about the appropriateness and efficacy of presidential administration, and the effects of the Constitution's separation of powers on the practical allocation of power between Congress and the President to control administrative action. Nevertheless, we should not leave this discussion of legal doctrine without noting the important role of judicial review. Separation of powers includes an independent judiciary whose decisions may reinforce one or the other political branch. Although administrative inaction is largely not subject to judicial review, thus leaving agenda setting ${ }^{16}$ and prosecutorial or enforcement discretion ${ }^{17}$ largely in executive hands, administrative action is presumptively subject to judicial oversight. ${ }^{18}$ Moreover, that review is premised on a search for an appropriate connection between the exercise of administrative power and the legislation under which the administrator has acted. Administrators must give reasons for their actions, and those reasons must explain how the actions promote

12. Humphrey's Ex'r v. United States, 295 U.S. 602 (1935).

13. Morrison v. Olson, 487 U.S. 654, 691 (1988).

14. Free Enter. Fund v. Pub. Co. Accounting Oversight Bd., 561 U.S. 477 (2010).

15. Id. at 524-30 (Breyer, J, dissenting).

16. Norton v. S. Utah Wilderness All., 542 U.S. 55, $61-67$ (2004) (finding agency discretion as to broad, programmatic policy choices to be generally unreviewable under the Administrative Procedure Act (APA)).

17. Heckler v. Chaney, 470 U.S. 821 (1985) (finding agency prosecutorial discretion is presumptively unreviewable).

18. Citizens to Pres. Overton Park, Inc. v. Volpe, 401 U.S. 402 (1971). 
or implement the policy specified in their governing statutes. 19 "The President told me to do it" is not a legal reason for agency action, except in those instances (largely concerning foreign affairs) in which the Constitution gives the President independent authority, or where Congress has statutorily delegated administration to the President.

To read press accounts of the day-to-day activities of the federal government is to imagine, many times quite accurately, that the White House (now a sprawling bureaucracy in its own right) controls all administrative action. Yet at the level of administrative law doctrine, when judicial review is available, the question is always whether an agency or department has exercised this discretion in accordance with its governing statute. Judicial review of administrative action is therefore dedicated to the defense of congressional policy choice-at least where that policy can be discerned.

\section{Theories of Presidential Administration: Presidentialism vs. Pluralism}

With these constitutional ambiguities in mind, we turn to the debate over the proper scope of presidential administration. In broad terms, theorists of presidential authority fall into two camps: presidentialists and pluralists. We will confine ourselves here to description of two leading accounts: Justice, then Professor, Elena Kagan's account of presidentialism and Professor Peter Shane's argument for pluralism. U.S. academic literature related to these theories is a torrent that offers intricate versions of the actual or appropriate extent of presidential power to control administrative action. ${ }^{20}$

A well-known article by Justice Kagan provides the paradigmatic scholarly presentation of presidentialism. ${ }^{21}$ Her article gives both a historical account of the ascendancy of "presidentialism" and argues for the normative desirability of this energetic vision of the presidency. On her account, modern presidentialism began in the Reagan Administration. While prior administrations generally avoided perceived direct intervention in regulatory processes like administrative rulemaking, President Reagan "self-consciously and openly adopted strategies to exert" direct and authoritative "influence" over the administrative state. ${ }^{22}$ Kagan identifies two key mechanisms that President Reagan used to bring his influence to bear. First, he used "his appointment power, perhaps more successfully than any other modern President, to staff the agencies with officials

19. See, e.g., D.C. Fed'n of Civic Ass'ns v. Volpe, 459 F.2d 1231, 1245-6 (D.C. Cir. 1971 ) (invalidating agency action because the agency made its decision based on impermissible political reasoning).

20. See, e.g., Daryl J. Levinson, Forward: Looking for Power in Public Law, 130 HARV. L. REV. 31, 34-35 (2016) (cataloguing sources on presidential authority).

21. Elena Kagan, Presidential Administration, 114 HARV. L. REV. 2245 (2001). Indeed, it is the most-cited American law review article from its year of publication. Fred R. Shapiro \& Michelle Pearse, The Most-Cited Law Review Articles of All Time, 110 MiCH. L. REV. 1483, 1495 tbl.2 (2012).

22. Kagan, supra note 21 , at 2277. 
remarkable for their personal loyalty and ideological commitment." and more innovatively, his Administration issued the now-iconic Executive Order 12,291. ${ }^{24}$ That order required that all (non-independent) agencies perform cost-benefit as well as cost effectiveness analyses for major rules, and mandated that agencies, to the extent permitted by law, follow the Order's stated policy goals. ${ }^{25}$ Agency analyses were made subject to review by the Office of Information and Regulatory Affairs (OIRA) in the Office of Management and Budget (OMB), a part of the Executive Office of the President (EOP) ${ }^{26}$

President Clinton is presented by Kagan as having "expanded dramatically" on President Reagan's innovations. ${ }^{27}$ To a greater degree, President Clinton "ma[de] the regulatory activity of the executive branch agencies more and more an extension of the President's own policy and political agenda."28 His administration, in its own Executive Order on OIRA and the regulatory process, built on the concepts in Reagan's EO 12,291 to claim more directly "that the President had authority to direct executive department ... heads in the exercise of their delegated rulemaking power." ${ }^{29}$ Even if statutes invested agency heads with authority, Clinton's EO implied that the President had the power to dictate how that authority was to be used. ${ }^{30}$

That implication was the basis for President Clinton's practice of "issuing formal directives to executive branch officials regarding the exercise of their statutory discretion."31 To those executive officials, these directives were, in Professor Kagan's telling, mandatory. Kagan argues that this directive authority changed "the understanding of agency and White House officials alike of their respective ... powers." 32 The effects of the President's assertion of his role as ultimate decider are difficult to trace to individual agency decisions, but on Kagan's account, it effected a broader revolution in administrative roles. ${ }^{33} \mathrm{~A}$ stronger identity arose between administration and the Administration.

23. Id.

24. Federal Regulation, Exec. Order No. 12,291, 46 Fed. Reg. 13,193 (Feb. 17, 1981).

25. Those goals included: (i) only pursuing regulatory action for which "the potential benefits to society for the regulation outweigh the potential costs" and (ii) choosing, from among possible regulatory policies, the policy with "the least net cost to society." Id. §2(b) \& (d).

26. See id. $\S 3$.

27. Kagan, supra note 21 , at 2248.

- 28. Id.

29. Id. at 2288; Regulatory Planning and Review, Exec. Order No. $12,866,58$ Fed. Reg. 51,735 (Oct. 4, 1993).

30. See John Yoo, An Executive Without Much Privilege, N.Y. TIMES (May 25, 2010), http:/www.nytimes.com/2010/05/26/opinion/26yoo.html [http://perma.cc/5XDP-VWJ7] ("Thus even if Congress, for example, gave the Environmental Protection Agency the job of setting clean air standards, President Clinton assumed the authority - without any direct permission in the law- to set the standards on his own.").

31. Kagan, supra note 21, at 2293. By Kagan's count, Reagan issued nine such directives, and Bush I issued four. Clinton issued 107. Id. at 2294-95.

32. Id. at 2299 .

33. Id. 
Kagan notes two aspects of Clinton Administration practice that are important to her subsequent normative justification of Clinton-style presidentialism. First, Kagan describes the careful, collaborative process behind these directives. ${ }^{34}$ Second, Kagan describes how President Clinton took "public ... ownership of agency action" commensurate with his claimed legal ownership. ${ }^{35}$ In what Kagan terms "appropriation," President Clinton publicly presented administrative action as his action. He thereby "set a new standard" of presidential communication with the public. ${ }^{36}$

Kagan argues that this strong presidential control of administration promotes both "accountability and effectiveness." the identity between the President and administration provides a transparency that "enable[es] the public to comprehend more accurately the sources and nature of bureaucratic power." 38 The President, as the sole politician with a national constituency, provides the best (or, alternatively, least bad) electoral link between the voting public and administration. ${ }^{39}$ The presumption here is that presidents are, like Clinton, public about their control of - and so accountable for-administration.

Presidential control also promotes "regulatory effectiveness," to Kagan, because the President brings "a certain kind of dynamism or energy to administration." In the era of divided government, the President can "provide energetic leadership in an inhospitable political environment." ${ }^{" 42}$ Congress may be too gridlocked to act, and the federal bureaucracy is allegedly too sclerotic to effect dynamic change. Enter the President, whose centralized control and policy vision can transcend this morass. Kagan acknowledges the "august lineage" of arguments "against this kind of activism" in American political theory, ${ }^{43}$ but she ultimately dismisses these Madisonian, separation-of-powers concerns. She finds sufficient comfort in the President's public accountability, ${ }^{44}$ as well as the remaining prerogatives of Congress and the courts. ${ }^{45}$

34. Id. at $2297-98$.

35. Id. at 2299 .

36. Id. at 2300 (quoting Lawrence R. Jacobs \& Robert Y. Shapiro, The Politicization of Public Opinion: The Fight for the Pulpit, in THE SOCIAL DIVIDE: POLITICAL PARTIES AND THE FUTURE OF ACTIVIST GOVERNMENT 96 (Margaret Weir ed., 1998)).

37. Id. at 2251-52.

38. Id. at 2331-32.

39. Id. at 2333-37. In her article, Kagan critiques a version of this electoral argument put forward by one of us, but her analysis nonetheless reaches a similar conclusion. For her, the President is the least-bad democratic link to administrative action. In politics, the best option rarely has more to recommend it than that.

$\begin{array}{ll}40 . & I d . \text { at } 2339 . \\ 41 . & I d . \\ 42 . & I d . \text { at } 2344 . \\ 43 . & I d . \text { at } 2342 . \\ 44 . & I d . \text { at } 2345-46 . \\ 45 . & \text { Id. at } 2346-52 .\end{array}$


As for concern that presidential control will privilege politics over expertise in agency decisions, Kagan makes two arguments. First, she minimizes the authority of expertise to "drive" major agency decisions. ${ }^{46}$ Second, she cautions that a properly presidentialist executive will show "restraint" before heavily interfering in "regulatory action that in large measure depends on scientific methodology."47

The contrary vision, the "pluralist" view of American government, is welldescribed and defended in Peter Shane's book Madison's Nightmare. ${ }^{48}$ Shane focuses on the presidentialist practices of the Bush II Administration. And where Kagan saw promise, Shane sees peril.

Descriptively, Shane picks up from where Kagan left off. President Clinton, as he writes, indeed "embraced unitary executive behavior by exerting increased political control of agencies." ${ }^{.49}$ Even if Shane would be willing to support some of President Clinton's administrative coordinating practices, ${ }^{50}$ he argues that the George W. Bush Administration "accelerat[ed] . . . presidentialist practice" to a "breathtaking" degree. 51 Bush II continued to employ Clintonian directive authority, ${ }^{52}$ but while Kagan (and the Clinton White House) did not promote an absolutist theory of a unitary executive, Bush II embraced it. Shane catalogues Bush's "expansion of every claim of executive power to the outer limits." $53 \mathrm{He}$ reviews the most aggressive claims, as embodied in Bush II's "signing statements" that he issued when signing legislation into law. ${ }^{54}$ These statements often sharply challenged the constitutionality of various aspects of congressional acts on the grounds that these laws, or some aspect of them, somehow impinged on the executive's absolute authority. ${ }^{55}$ President Bush's broad conception of executive control also included control over information. ${ }^{56}$

46. Id. at 2353 ("Bureaucratic expertise, for reasons I have indicated earlier, cannot alone or even predominantly drive administrative decisions.").

47. Id. at 2356 .

48. PETER M. SHANe, MAdison's NightMaRe: How EXeCUTIVE POWER THREATENS AMERICAN DEMOCRACY (2009).

49. Id. at 154 .

50. See id. at 166-67 ("[T]he Clinton executive 'order process-without further presidential control of subordinate administrators' discretion-represents the high-water mark of what ought to be tolerable in terms of centralization.").

51. Id. at 155 .

52. E.g., id. at $155-58$.

53. Id. at 132 .

54. Id. at 132-45. Signing statements are, in essence, presidential commentary on a given bill that the President is signing. They can range from platitudinous praise of the enacted law to serious interpretive, policy, or constitutional reservations. Shane readily admits that many individual signing statements may have addressed executive authority on "obscure matters," but these stances "help[] to maintain the attitudes-the norms of governance-that lead to other, more consequential claims of unilateral executive authority." Id. at 142 .

55. See Peter L. Strauss, Overseer, or "The Decider"? The President in Administrative Law, 75 GEO. WASH. L. REV. 696, 721 (2007).

56. SHANE, supra note 48 , at 121-32. 
Like Clinton, Shane notes that the Bush Administration paid attention to legal process and authority in its practice of presidentialism. ${ }^{57}$ However, Shane argues that, at least under Bush, these processes to validate authority became empty and formalistic. The President did not "claim[] to be above the law," 58 but in the hands of Bush Administration lawyers, the law became mere "piece[s] of paper ... to hold up as authoritative legal support for any claim of executive authority." 59

At the most basic level, Kagan and Shane make the same descriptive point. Kagan reveals how executive authority expanded during the Clinton years; Shane illustrates how that expansion accelerated under Bush II. Shane argues that, once the President is personally granted directive authority over the administrative state, this expansion is inevitable. In his terms, presidentialism's "usurpation of authority works as a one-way ratchet." ${ }^{.60}$ Regardless of party, subsequent Presidents "will be tempted to embrace their predecessors' more audacious claims as sources of legal authority and strike out on their own."61 Kagan may find an ideal balance in Clinton's presidentialism, but in Shane's view, Kagan-style presidentialism necessarily accretes power, like a planet gravitationally pulling in mass.

In the context of this ever-growing presidential power, Shane disputes Kagan's normative arguments that presidentialism fosters effectiveness and accountability. ${ }^{62}$ On accountability, Shane brings a critical, realpolitik perspective to Kagan's claim of "appropriation." According to Shane, presidential administration becomes a means to use information control to thwart accountability when politically advantageous. To this end, Shane describes the Bush Administration's culture of secrecy around executive action, from opposition to FOIA requests and assertions of executive privilege to purges of government data and information. ${ }^{63}$ The administration thus kept the public from the information it needs to evaluate administrative policy. ${ }^{64}$ Kagan concedes that this could be a problem, but Shane views it as the norm.

57. E.g., id. at 112 (describing President Bush's claimed legal basis for enhanced interrogation techniques and extraordinary rendition).

58. Id. at 112 .

59. Id. at 114 .

60. Id. at 4; see also Charle SAVAGE, POWER WARS: InSIDE Obama's POST-9/11 PRESIDENCY 663 (2015) ("[E]xecutive power tends to act like a ratchet: a president does something unprecedented that seems like the new outer boundary, but then a successor treats that as a baseline and goes even further.").

61. SHANE, supra note 48 , at 4 .

62. Separately from these policy arguments, he also argues that pluralism has a stronger constitutional basis than unitarianism. Id. at 37-42. On unitary executive claims of authority beyond Clintonian presidentialism, Kagan seemingly agrees. Kagan, supra note 21, at 2326-27. This paper does not address these constitutional questions. The irresolvable debate over them is as prolific as the relevant constitutional text is sparse.

63. SHANE, supra note 48, at 121-32; see id. at 157.

64. Id. at 165 . Shane also contests the viability of the electoral link between the President and the national populous that is central to the accountability claim. $I d$. at 161 . However, his 
On efficacy, we think Shane can be read to make two primary points. First, he argues that presidentialists fail to consider sufficiently the costs of presidential involvement. As he writes, "the substantial regulatory delays entailed in White House review impose billions of dollars of 'social cost' - a euphemism for the illness, injuries, and even deaths that could have been forestalled had agencies been permitted to proceed with greater independence." Kagan's exhortation against presidentialist intervention in scientific judgment, ${ }^{66}$ Shane argues that some of the most serious costs accrue from precisely that. ${ }^{67}$ Second, more broadly, Shane sees ever-growing presidential control as simply a bad mechanism for decision-making. As he writes, in a passage that deserves full quotation:

[L]ooking at the unilateral presidency in action shows us that the growth of executive power is all too likely to produce dysfunctional government, no matter which party is in control. Adopted as an ethos of government, aggressive presidentialism breeds an insularity, defensiveness, and even arrogance within the executive branch that undermines sound decision making, discounts the rule of law, and attenuates the role of authentic deliberation in shaping political outcomes. ${ }^{68}$

One imagines recent developments have only increased Shane's confidence in this proposition.

As this Article moves to its case studies in Part IV, there will be multiple opportunities to reflect on how recent events reinforce or weaken the assumptions and arguments for Shane's pluralism or Kagan's presidentialism. And we, like those authors, will doubtless find our analysis held hostage to the presidential practices we choose to observe.

\section{Separation of Powers vs. Separation of Parties}

Competing theories of separation of powers are central to the presidentialist and pluralist visions of presidential direction and control of administration. Most

arguments are similar to Kagan's misgivings on this point. The difference is she fails to see a better alternative. Kagan, supra note 21 , at 2336.

65. Id. at 173.

66. Kagan, supra note 21 , at 2356.

67. SHANE, supra note 48 , at 167 (describing "[t] $]$ he pressure on agency experts to downplay the threat of global warming and White House intervention in the editing of documents to portray the scientific consensus as weaker than it is ....").

68. Id. at 25. Cf. Jack H. Knott \& Gary J. Miller, When Ambition Checks Ambition: Bureaucratic Trustees and the Separation of Powers, 38 AM. REV. PUB. ADMIN. 387, 401 (2008) (arguing that administrators should act more like trustees than agents with respect to their delegated authority, since "[t]he respect given to regulatory agencies is largely correlated with its demonstrated responsiveness to professional norms and standards rather than its" immediate responsiveness to political pressure); Levinson \& Pildes, supra note 1, at 2379 ("Politicization of the bureaucracy in the post-World War II era, whatever its benefits in terms of democratic accountability and political realism, has gradually eroded the capacity of bureaucratic institutions to check and balance unified party government. Perhaps constitutional and administrative lawyers and theorists should take a closer look at what has been lost."). 
scholarship analyzing administrative and constitutional limits on presidential administration features separation-of-powers concerns. ${ }^{69}$ These concerns respond to a basic feature of American political and constitutional ideology: the belief that the separation-of-powers system is the central bulwark against overweening governmental power and the destruction of individual liberty. ${ }^{70}$

From a comparative perspective, the fact of separated or unified powers influences, even if it does not fully determine, the exercise of administrative discretion. In his magisterial study of administrative control regimes in the United Kingdom, United States and Australia, Professor Peter Cane argues that "significant differences between control regimes" that check and channel administration in the studied countries "may be partly explicable in terms of differences between the systems of government of" those countries (and that comparative similarities in administrative control regimes likewise derive from similarities in government systems). ${ }^{71}$ The "systems of government" that Cane examines in detail are distinguished at a very general level by their tendency to concentrate or diffuse political power. Cane explains this distinction in the following terms:

A fundamental difference between diffusion and concentration is that under diffusion, the various empowered institutions are separately and distinctly authorized to exercise whatever powers they have been given, and are in that sense 'coordinate.' By contrast, under concentration, authority is ultimately derived from a single 'sovereign' institution to which all other institutions are in some sense subordinate. For instance (as we will see in much more detail later), in the U.S. system the three traditional branches of government--legislature, executive and judiciary - are each understood to exercise power delegated to them directly by 'the People,' in whom 'sovereignty' is said to reside. By contrast, in the English system (in theory at least) 'sovereignty' resides in the Queen-inParliament, and the authority of the executive and the judiciary is ultimately subject to that sovereignty. ${ }^{72}$

The American belief in the efficacy of separation of powers to preserve liberty and limit government is certainly plausible. So, indeed, is Professor Cane's argument that control regimes with respect to administrative power are explained, at least in part, by the degree of concentration or diffusion of power

69. See, e.g., Gillian E. Metzger, Ordinary Administrative Law as Constitutional Common Law, 110 Colum. L. REV. 479 (2010); Jon D. Michaels, An Enduring, Evolving Separation of Powers, 115 Colum. L. REv. 515, 519 (2015); see also John Ferejohn, Power in Public Law: Some Reactions, 130 HARV. L. REV. F. 9, 17 (2016) ("The administrative state continually raises powerseparation issues."); Peter L. Strauss, Presidential Rulemaking, 72 CHI.-KENT L. REV. 965, 974-75, 97980 (1997) (discussing separation-of-powers issues in the rulemaking context).

70. This view was most famously promoted by James Madison in Federalist 51. THE FEDeralist No. 51 (James Madison) (Clinton Rossiter ed., 1961).

71. Peter Cane, Controlling administrative POWER: AN Historical PERSPECTIVE 11 (2016).

$$
\text { 72. Id. at } 5 \text {. }
$$


in the constitutional system generally. But these beliefs and arguments have not gone unchallenged.

Professors Daryl Levinson and Richard Pildes, for example, argue that separation of powers is, independent of divided government, functionally close to meaningless in terms of explaining the degree of control exercised by Congress over administration. ${ }^{73}$ On their view, contrary to the vision of the Constitution's drafters, ${ }^{74}$ interbranch competition (and, thus, checking and balancing) does not derive from inherent structural tension-what they call "paper partition between the branches." R5 Rather, any competition (or its absence) is attributable to political alignment and opposition between branches. ${ }^{76}$ As they write, partisan identity between Congress and the President is "sometimes more binding than law" and extends the President's "effective control into branches of government other than his own."

They largely reject the functional importance of branches as competing institutions because "government institutions do not have wills or interests of their own; their behavior is a product of the wills or interests that motivate the individual officials who compose them." $"$ "As the political parties to which those individuals belong have become "more internally unified, ideologically coherent, and polarized ... than we have seen in many decades,"79 partisan allegiance supersedes any sense of institutional prerogative. In unified government during this partisan age, Congress and the President will "cooperat[e]" rather than compete. ${ }^{80}$ In terms of policy durability, unified government is what potentially "offer[s] the prevailing party an opportunity to build an enduring political consensus or movement of the sort that generates historically dramatic change." 81 Of course the converse is also true: divided government has the opposite effect only because the separation of powers facilitates division.

In evaluating Levinson and Pildes' claims, comparing the experience of the later Obama and early Trump Administrations is especially instructive, since they provide examples of both hyper-partisan divided and hyper-partisan unified government. While Levinson and Pildes are certainly right that partisan division or unity affects the efficacy of separation of powers as a control mechanism, this

73. Levinson \& Pildes, supra note 1; Levinson, supra note 20, at 90-91.

74. Levinson \& Pildes, supra note 1, at 2315 ("[T] he separation of powers no longer works as originally envisioned because interbranch dynamics have changed with the rise of political parties.").

75. Id. at 2314 .

76. As they argue, the "invisibility of political parties" to judicial and scholarly conceptions of separation of powers has seriously undercut the functional validity of those conceptions. Id.

77. Id. at 2314-15 (quoting Youngstown Sheet \& Tube Co. v. Sawyer, 343 U.S. 579, 610-11 (1952) (Jackson, J, concurring).

78. Id. at 2317.

79. Id. at 2338 .

80. . Id. at 2316 .

81. Id. at 2340 . 
Article's case studies suggest that separation of powers is not bereft of institutional meaning.

First, a focus on hyper-partisanship ignores remaining ideological and interest-based conflict within both parties. Second, while institutions themselves do not have inherent interests, the structure of those institutions (and the assumption of particular roles within those institutions) can still shape the interests of officials. This premise takes us back to Professor Cane's comparative work. As he notes, "even in periods of unified government, [American] Presidents have significantly less control over Congress than Prime Ministers in England and Australia typically enjoy over their respective Parliaments."82 $\mathrm{He}$ points to government structure in a broad sense-from the organization of elections to the institutional role of the President relative to Congress-to explain this comparative difference. ${ }^{83}$ This comparison arguably shows, in other words, that institutional separation of powers still has importance in understanding the practice and extent of presidential administration. That understanding must be politically informed in a polity widely recognized to reflect increasing partisan divisions, but checks on presidentialism are not wholly a function of partisan competition.

Finally, the Levinson and Pildes analysis, focused as it was on the two political branches, ignores the third branch of American government. In particular, that analysis fails to note that the basic approach to judicial review of administrative action in the United States reinforces congressional control-just not necessarily the control of current congresses. In determining the legality of administrative action, courts tend to ask a series of questions that treat the legislative mandate under which an official acts as the critical touchstone for administrative legitimacy. Courts ask whether the agency's approach flows from a correct, or at least reasonable, construction of its organic statute. They ask, in addition, whether the agency's fact-finding upon which its actions are predicated address the relevant considerations-that is, the considerations made relevant by the agency's statute. ${ }^{84}$ In this way, the Judiciary reinforces the authority of Congress as an institution, whatever the partisan composition of the current Congress might be.

\section{Case Studies in Presidential Administration}

We turn now to three policy case studies from the Obama and Trump Administrations to provide specific contexts within which to assess the

82. CANE, supra note 71 , at 107.

83. Professor Cane notes increased U.S. partisanship, in contrast to the increase in less partisan pragmatism in the United Kingdom and Australia, may decrease the relative institutional friction between a unified President and Congress. $I d$. at 110 . However, we read his point here as a matter of degree, rather than abrogating the overall comparative claim.

84. See, e.g., D.C. Fed'n of Civic Ass'ns v. Volpe, 459 F.2d 1231, 1245-46 (D.C. Cir. 
contemporary state of presidential administration. Of course, the ink is still wet on the history of the Obama years, and the experience of the Trump Administration changes daily. Thus, these case studies are necessarily preliminary, particularly with regard to President Trump.

\section{A. Immigration Policy}

Under both Obama and Trump (thus far), immigration policy has been a major focus of presidential administration. Immigration enforcement policy underwent major and well-publicized changes during President Obama's second term, and President Trump was elected promising to undo those changes. It is thus an ideal policy area in which to observe how presidential administration is practiced in ideologically opposed administrations and to observe the durability of independent presidential policymaking.

\section{Obama: DACA \& DAPA}

In mid-June 2012, in the middle of his re-election campaign, President Obama gave a speech from the Rose Garden to announce-one could say, in Kagan's sense of the word, "appropriate"-what would be come to be known as "DACA," Deferred Action for Childhood Arrivals. ${ }^{85}$ As the President explained, DACA would formally defer deportation action against (and potentially give legal work authorization to) certain young, undocumented immigrants who had arrived in the United States as children and had not committed crimes. He presented DACA as a "temporary stopgap" and called for congressional action to codify the program. ${ }^{86}$ DACA represented the beginning of Obama's shift from a presidential administration with the highest deportation rate in history to one that aimed to narrow dramatically those subject to deportation. ${ }^{87}$

DACA was articulated in a memorandum from Department of Homeland Security (DHS) Secretary Janet Napolitano to the Director of the U.S. Citizenship and Immigration Services (USCIS) and the Director of the U.S. Immigration and Customs Enforcement (ICE), along with the Acting Commissioner of U.S. Customs and Border Protection (CBP). ${ }^{88}$ The complex

85. Press Release, White House Office of the Press Sec'y, Remarks by the President on Immigration (June 15, 2012), http://obamawhitehouse.archives gov/the-press-office/2012/06/15/remarkspresident-immigration [http://perma.cc/H649-JW41]; Tom Cohen, Obama Administration To Stop Deporting Some Young Illegal Immigrants, CNN (June 16, 2012), http:/www.cnn.com/2012/06/15/ politics/immigration [http://perma.cc/LGY7-3WUL].

86. Press Release, supra note 85.

87. See Ana Gonzalez-Barrera \& Jens Manuel Krogstad, U.S. Deportations of Immigrants Reach Record High in 2013, PEW RES. CTR., http://www.pewresearch.org/fact$\operatorname{tank} / 2014 / 10 / 02 / \mathrm{u}$-s-deportations-of-immigrants-reach-record-high-in-2013 [http://perma.cc/438T2PTS].

88. Memorandum from Janet Napolitano, Sec'y, Dep't of Homeland Sec, to David V. Aguilar, Acting Comm., USCBP, et al. (June 15, 2012) [hereinafter DACA Memo], 
statutes governing immigration policy delegate the development of enforcement authority to the Secretary of the Department of Homeland Security, not the President. The DACA memo was careful to frame the program as a non-binding exercise of "prosecutorial discretion" vested in the DHS Secretary. ${ }^{89}$ Per Obama's Rose Garden address, the memorandum instructed U.S. immigration authorities to forebear enforcement against certain young, undocumented immigrants. ${ }^{90}$ A memo, released the same day by the ICE Director to all ICE employees, explained that employees should implement DACA by "exercis[ing] their discretion, on an individual basis." This focus on discretion and (at least nominally) individual judgment by line officers was intended to avoid the claim (which litigation over DACA ultimately sidestepped) ${ }^{92}$ that in issuing this guidance, DHS had in fact issued a rule that was invalid because it was not adopted pursuant to the procedural requirements of the Administrative Procedure Act (the APA).$^{93}$ Through the end of 2016 , over 1.1 million immigrants would receive deferred action under DACA. ${ }^{94}$

On November 20,2014, President Obama again stepped to the podium to make an appropriative announcement. This time it was to announce Deferred

http://www.dhs.gov/xlibrary/assets/s1-exercising-prosecutorial-discretion-individuals-who-came-to-usas-children.pdf [http://perma.cc/5XUW-LMEH].

89. Adam B. Cox \& Cristina M. Rodriguez, The President and Immigration Law Redux, 125 YALE L.J. 104, 139-40 (2015) ("To underscore that the initiative fell within the President's enforcement powers, the Administration emphasized that DACA would not confer a lawful status on its recipients, that the adjudicators of DACA petitions in ... USCIS ... retained discretion to deny applications of even those who satisfied the eligibility criteria, and that DHS retained the discretion to terminate the status at any time.").

90. DACA Memo, supra note 88, at 1 ; Press Release, supra note 85.

91. Memorandum from John Morton, Dir., Immigration \& Customs Enf't, to All Employees (June 15, 2012), http://www.ice.gov/doclib/about/offices/ero/pdf/s 1 -certain-young-peoplemorton.pdf [http://perma.cc/5EQP-7ZJ7].

92. See Crane v. Napolitano, No. 3:12-CV-03247-O, 2013 WL 8211660 , at *7 (N.D. Tex. July 31, 2013); Crane v. Johnson, 783 F.3d 244 (5th Cir. 2015). The lower court sidestepped the APA issue by finding it lacked subject matter jurisdiction; the appellate court likewise avoided the merits by finding the plaintiffs lacked standing.

93. The APA provides certain "general law about administrative procedure and control" that applies trans-substantively to the actions of federal agencies, in addition to any requirements in agency-specific statutes. Whenever an agency acts, it must meet the applicable procedural standards that the APA imposes. 1 CHARLES H. KOCH, JR. \& RICHARD MURPHY, ADMINISTRATIVE LAW \& PRACTICE $\S$ $2: 30$ (2016). Under informal rulemaking, the agency must provide pre-promulgation notice in the Federal Register of its proposed rulemaking, including "the terms or substance of the proposed rule or a description of the subjects and issues involved." 5 U.S.C. $\S 553(\mathrm{~b})(3)(2018)$. Interested parties are then allowed to respond with "data, views, or arguments" to the proposed rule. Id. $\S 553(\mathrm{c})$. After "consideration of the relevant matter presented," the agency then publishes the final rule, along with "a concise general statement of [its] . . basis and purpose." Id. Courts can then review the agency's decisionmaking process under the same "arbitrary [or] capricious" standard for general reasonableness review. Id. $\S 706(2)(\mathrm{A})$. Reviewing courts can vacate or otherwise remand a rule for failure to comply with these APA requirements. Id. $\S 706(2)(\mathrm{D})$.

94. U.S. Citizenship \& Immigration Servs., Number of $1-821 D$, Consideration of Deferred Action for Childhood Arrivals by Fiscal Year, Quarter, Intake, Biometrics and Case Status FY 2012-2017, U.S. DEP'T HOMELAND SECURITY (2017), http://www.uscis.gov/sites/default/files/USCIS/ Resources/Reports\%20and\%20Studies/Immigration\%20Forms\%20Data/All\%20Form\%20Types/ DACA/daca_performancedata_fy2017_qtrl .pdf [http://perma.cc/6M4D-5AVW]. 
Action for Parents of Americans, "DAPA,"95 which expanded eligibility for DACA and created a new deferred action program for undocumented parents of U.S. citizens or lawful permanent residents. Again, he presented his executive action as something that legislation should supersede. ${ }^{96}$ The potential DAPAeligible population-estimated at around four million undocumented immigrants - was far larger than DACA.$^{97}$ DAPA was again embodied in a memorandum from the DHS Secretary addressed to the same high-level immigration officials as the DACA memo. ${ }^{98}$ The memorandum instructed DHS enforcement personnel to defer deportation action with respect to those undocumented parents who had resided in the United States for a given amount of time, provided there are no other grounds for believing that particular individuals should be an enforcement priority.

As with DACA, the DAPA memo was carefully phrased in terms of discretion and (at least nominal) case-by-case adjudication ${ }^{99}$-an attempt to . characterize DAPA's discretionary priorities like routine guidance concerning the exercise of prosecutorial discretion. ${ }^{100} \mathrm{Had}$ the Secretary's memorandum been viewed in that way, then no procedure would have been required to promulgate it. Absent some violation of a statutory requirement that mandated deportation of these undocumented aliens, the Secretary's exercise of prosecutorial discretion would be, under standard doctrine, not subject to judicial review. ${ }^{101}$

But it is on this point that DAPA foundered in the courts. The Fifth Circuit Court of Appeals ruled that DAPA was not non-binding guidance (and therefore exempt from APA rulemaking requirements), ${ }^{102}$ but a binding rule under the

95. Press Release, White House Office of the Press Sec'y, Remarks by the President in Address to the Nation on Immigration (Nov. 20, 2014), http://www.whitehouse.gov/the-pressoffice/2014/11/20/remarks-president-address-nation-immigration [http://perma.cc/RT38-J27P].

96. Id. ("I want to work with both parties to pass a more permanent legislative solution. And the day I sign that bill into law, the actions I take will no longer be necessary.").

97. Press Release, Migration Pol'y Inst., As Many as 3.7 Million Unauthorized Immigrants Could Get Relief from Deportation Under Anticipated New Deferred Action Program (Nov. 19, 2014), http://www.migrationpolicy.org/news/mpi-many-37-million-unauthorized-immigrants-couldget-relief-deportation-under-anticipated-new [http://perma.cc/KB57-BQ4P].

98. Memorandum from Jeh Johnson, Sec'y, Dep't of Homeland Sec., to León Rodriguez, Dir., USCIS, et al. (Nov. 20, 2014), http:/www.dhs.gov/sites/default/files/publications/ 14_1120_memo_deferred_action.pdf [http://perma.cc/28LM-GBH3].

99. Id. at 5 ("[T] $]$ he ultimate judgment as to whether an immigrant is granted deferred action will be determined on a case-by-case basis.").

100. Id. at 1 ("As is true of virtually every other law enforcement agency, DHS must exercise prosecutorial discretion in the enforcement of the law.").

101. See Heckler v. Chaney, 470 U.S. 821 (1985) (finding agency prosecutorial discretion is presumptively unreviewable). Such exercises of discretion are sometimes referred to as black or gray holes in administrative law, circumstances in which administrators act free, or almost free, from any legal constraints. See Adrian Vermeule, Our Schmittian Administrative Law, 122 HARV. L. REV. 1095 (2009).

102. See 5 U.S.C. $\S 553(\mathrm{~b})(3)(\mathrm{A})(2012)$ (exempting "general statements of policy" from notice and comment). 
APA. ${ }^{103}$ Interestingly, the Fifth Circuit adduced the President's own public statements to support its finding that DAPA was meant to be binding. ${ }^{104}$ As a binding rule, DAPA was procedurally invalid for failure to follow the APA's notice-and-comment rulemaking process. According to the Court of Appeals, the finding that the Secretary's memorandum was, in fact, a rule in disguise had substantive consequences as well. To adopt a rule, rather than merely exercise discretionary authority to set enforcement priorities, the Secretary would need to show that DHS had authority under existing immigration statutes to adopt rules making certain categories of deportable aliens non-deportable and give reasons for the exercise of that authority in this particular way. ${ }^{105}$ The court found no such authority in the statute. ${ }^{106}$ The sitting, and often gridlocked, Congress could not undo DAPA. But judicial review, predicated on an interpretation of the APA and the immigration statutes as enacted by prior congresses, could do so. ${ }^{107}$

In timing and substance, the decisions to implement both DACA and DAPA through executive action were politically and electorally informed. In both cases, President Obama decided to implement the programs after a gridlocked Congress failed to pass legislation resolving the issues that DACA and DAPA addressed. For DACA, the precedent legislative failure was the "DREAM Act," 108 which would have statutorily provided for DACA-like deferred action for young, undocumented immigrants (often called Dreamers). ${ }^{109}$ Soon after the DREAM Act failed, Obama publicly disclaimed unilateral executive authority to protect Dreamers. ${ }^{110}$ Nevertheless, he announced DACA "the summer before the 2012 presidential election, leading some commentators to conclude the President's quest for . . . a strong showing among Latino voters motivated the decision." 111

Similarly, Obama turned to DAPA when conservatives in the House blocked a comprehensive immigration reform bill. ${ }^{112}$ When it "was clear that

103. Texas v. United States, 809 F.3d 134, 171-76 (5th Cir. 2015), aff'd by an equally divided court, 136 S. Ct. 2271 (2016).

104. Id. at 173 ("In denying the government's motion for a stay of the injunction, the district court further noted that the President had made public statements suggesting that in reviewing applications pursuant to DAPA, DHS officials who 'don't follow the policy' will face 'consequences,' and 'they've got a problem."').

105. Id. at $178-86$

106. Id.

107. We will not here discuss the problematic position of the Fifth Circuit in Texas $v$. United States, 809 F.3d 134. Suffice it to say that reasonable and well-informed administrative lawyers could disagree with virtually every finding in that opinion.

108. DREAM Act of 2010, S. 3992, 111 th Cong. (2010), http://www.congress.gov/111/ bills/s3992/BILLS-111s3992pcs.pdf [http://perma.cc/99PA-BLQ2].

109. Indeed, the DREAM Act's eligibility criteria were almost identical to DACA. Id. $\S 4$.

110. See, e.g., SAVAGE, supra note 60 , at 656 ; Josh Blackman, Presidential Maladministration, U. ILL. L. REV. 61-62 (forthcoming 2018), http://papers.ssrn.com/sol3/papers.cfm? abstract id=2888172 [http://perma.cc/EP7A-NC6U].

111. Cox \& Rodríguez, supra note 89 , at 218 n.317.

112. SAVAGE, supra note 60 , at 656 . 
Congress would not enact any immigration reform legislation before Obama's presidency was over," 113 he decided to push his executive authority to the limits of what his legal advisors would countenance as lawful. ${ }^{114}$ As with DACA, Obama had previously disclaimed the ability to implement a DAPA-type program unilaterally. ${ }^{115}$ This time, it is commonly believed that the Obama Administration waited to announce DAPA until after the 2014 midterm elections, to avoid harming Democratic candidates in districts unsympathetic to leniency in immigration enforcement. ${ }^{116}$

But even if electoral politics influenced DAPA and DACA, both actions still had serious legal reasoning and process behind them. As journalist Charlie Savage wrote about DAPA, Obama's "policy-decision process, characteristically, was heavily legalized." 117 The Justice Department's Office of Legal Counsel (OLC) had informally blessed DACA. ${ }^{118}$ In formulating DAPA, White House counsel Neil Eggleston, OLC, and DHS lawyers collaborated on the shape of the program. ${ }^{119}$

The memorandum that OLC ultimately prepared concerning DAPA's legality ${ }^{120}$ advised the Secretary that deferred action would be legally acceptable only to the extent that the Secretary could find in legislation some close analogue to the category of persons that the Secretary chose for deferral. ${ }^{121}$ In OLC's view, such a case could be made for the DACA program, but not for all aspects of DAPA, as the White House initially conceived of it. ${ }^{122}$ Specifically, OLC found

\footnotetext{
113. Id. at 661 .

114. Juliet Eilperin et al,, Obama's Evolution on Immigration, WASH. PosT (Nov. 20, 2014), http://www.washingtonpost.com/politics/obamas-evolution-on-immigration/2014/1 1/20/ 856c5564-70d5-1 le4-ad12-3734c461eab6_story.html [http://perma.cc/WW9Y-CCVC].

115. Press Release, White House Office of the Press Sec'y, Remarks by the President at Univision Town Hall with Jorge Ramos and Maria Elena Salinas (Sept. 20, 2012), http://obamawhitehouse.archives.gov/the-press-office/2012/09/20/remarks-president-univision-townhall-jorge-ramos-and-maria-elena-salina [http://perma.cc/STM5-JPBV] (responding to a question of whether he could provide deferred action for immigrant parents, President Obama said: "Now, what I've always said is, as the head of the executive branch, there's a limit to what I can do .... [W] e're still going to, ultimately, have to change the laws in order to avoid some of the heartbreaking stories that you see coming up occasionally.").
}

116. Eilperin et al., supra note 114.

117. SAVAGE, supra note 60 , at 661 .

118. Blackman, supra note 110 , at 62 .

119. SAVAGE, supra note 60, at 661-62.

120. Memorandum from Karl R. Thompson, Dep't of Justice, Office of Legal Counsel, to Jeh Johnson, Sec'y of Homeland Sec. \& W. Neil Eggleston, Counsel to the President (Nov. 19, 2014), http://www.justice.gov/sites/default/files/olc/opinions/attachments/2014/11/20/2014-11-19-authprioritize-removal.pdf [http://perma.cc/5VDC-9N6A].

121. See id. at 24 ("[A]ny expansion of deferred action to new classes of aliens must be carefully scrutinized to ensure that it ... does not seek to effectively rewrite the laws to match the Executive's policy preferences, but rather operates in a manner consonant with congressional policy expressed in the statute."). But see Cox \& Rodríguez, supra note 89, at 151 ("The appeal of the congressional priorities approach is understandable. But we do not believe it provides an effective principle for limiting executive branch enforcement judgments in immigration law and many other domains. The congressional priorities approach fails because those priorities are a mirage."). 33.

122. See Memorandum from Karl R. Thompson to Jeh Johnson, supra note 120, at 25 - 
sufficient statutory support for DAPA insofar as it deferred action for deportable parents whose children were U.S. citizens or lawful permanent residents, but not for deportable parents whose children were themselves granted deferred action under DACA. The Administration proceeded in accordance with OLC's opinion. ${ }^{123}$ The DAPA program thus both seized a prerogative previously said to lie with Congress, but also respected congressional authority by limiting its reach to categories of aliens favored by immigration statutes.

Professors Cox and Rodriguez recognized the importance of this rise of presidentialism as administrative practice, arguing that " $[t]$ he long-term trend in American bureaucracy has been toward centralization ... elevating decisions within agencies themselves, as well as above agencies into the Executive Office of the President." ${ }^{24}$ Moreover, they note that this shift has to some degree been codified within immigration statutes, which over time have vested more discretion and authority for immigration policy in the President and his appointees. ${ }^{125}$ This statutory authority, particularly as it involves enforcement priorities, is what convinced the Obama Administration that it had legal authority to implement DACA and DAPA. But as Cox and Rodriguez presciently noted, this presidentialism in immigration allows "[a] single decision of a future administration ... [to] reverse the non-enforcement decisions with respect to millions of noncitizens." 126

\section{Trump: The Travel Ban, DACA Retention \& the Enforcement Boom}

With the inauguration of President Trump, U.S. immigration policy shifted radically, although not one immigration statute changed between the two presidencies. $^{127}$ This Part will briefly describe three sets of immigration developments under Trump: his "travel ban"; ${ }^{128}$ his approach to DACA; and his Administration's rapid and massive ramp-up of deportation-oriented immigration enforcement. ${ }^{129}$

123. See Memorandum from Jeh Johnson to León Rodriguez, supra note 98, at 4-5.

124. Cox \& Rodríguez, supra note 89 , at 184.

125. Id. at 194-95.

126. Id. at 208 .

127. See Michael D. Shear \& Julie Hirschfeld Davis, Stoking Fears, Trump Defied Bureaucracy To Advance Immigration Agenda, N.Y. TIMES (Dec. 23, 2017), http://www.nytimes.com/ 2017/12/23/us/politics/trump-immigration.html [http://perma.cc/863K-MDGT].

128. The Trump Administration argues that the executive orders discussed here are not instantiations of the "Muslim Ban" that Trump promised during his campaign. Ron Nixon \& Nicholas Kulish, Homeland Security Chief Admits Travel Ban Was Rushed, N.Y. TIMES (Feb. 7, 2017), http:// www.nytimes.com/2017/02/07/us/travel-ban-customs-border-protection.html [http://perma.cc/2UDFEYBA]. We will refer to this policy as the travel ban, but we note the reasoning of Hawaii District Court Judge Watson. Hawai'i v. Trump, 241 F. Supp. 3d 1119, 1135-36 (D. Haw. 2017).

129. We do not treat here the Trump Administration's attempt to combat so-called "sanctuary cities," which Professor Strauss describes in his article. PETER L. STRAUSS, AMERICAN ADMINISTRATIVE LAW UNDER THE PRESIDENCY OF DONALD TRUMP 7 (May 2017) (on file with authors). 
First, the travel ban. Shortly after assuming office, President Trump held a public signing ceremony for Executive Order 13,769 at the Pentagon. The venue underscored the purported national security basis for the President's action. ${ }^{130}$ He described the Order as part of new vetting measures to keep "radical Islamic terrorists" out of" the United States. ${ }^{131}$ In its key provisions, the Order (i) suspended essentially all immigration and alien travel from seven countries: Iraq, Iran, Libya, Somalia, Sudan, Syria, and Yemen; ${ }^{132}$ (ii) shut down all U.S. refugee admissions for four months ${ }^{133}$ (and all Syrian refugee admissions indefinitely) ${ }^{134}$; and (iii) for future refugee admissions, instructed prioritization for "refugee claims made by individuals on the basis of religious-based persecution, provided that the religion of the individual is a minority religion in the individual's country of nationality." ${ }^{135}$ Unlike the DACA and DAPA memos, the travel ban was not presented as agency-level guidance, but came as instructions to agency heads directly from the President.

The world is familiar with what resulted. ${ }^{136}$ The nation's airports were filled with "confusion and chaos and protests" as immigrants and refugees with previously valid travel documents were detained at U.S. airports, while others were prevented from boarding planes into the United States. ${ }^{137}$ The chaotic implementation stemmed at least in part from the furtive and rushed legal process behind the order. Allegedly, neither the DHS secretary nor the Secretary of Defense was involved in any legal review of the original EO. ${ }^{138}$ Instead, a "small White House team"' led by Steve Bannon drafted the Order in relative secrecy. ${ }^{139}$ Even Republican congressmen criticized the dearth of legal process. ${ }^{140}$

In response to criticism, the White House alleged that OLC had blessed the ban, but the OLC memo that they released-dated the same day that the Order

130. See Michael D. Shear \& Helene Cooper, Trump Bars Refugees and Citizens of 7 Muslim Countries, N.Y. TIMES (Jan. 27, 2017), http://www.nytimes.com/2017/01/27/us/politics/trumpsyrian-refugees.html [http://perma.cc/C3KG-NDS5].

131. Id.

132. See Protecting the Nation from Foreign Terrorist Entry Into the United States, Exec. Order No. 13,769, 82 Fed. Reg. 8,977, 8,978 §3(c) (Feb. 1, 2017).

133. Id. $\$ 5(\mathrm{a})$.

134. Id. $\$ 5(\mathrm{c})$.

135. Id. § 5(b); see also Washington v. Trump, 847 F.3d 1151, 1156-57 (9th Cir. 2017), reconsideration en banc denied, No. 17-35105, 2017 WL 992527 (9th Cir. Mar. 15, 2017).

136. Michael D. Shear \& Ron Nixon, How Trump's Rush to Enact an Immigration Ban Unleashed Global Chaos, N.Y. TIMES (Jan. 29, 2017), http://www.nytimes.com/2017/01/29/us/politics/ donald-trump-rush-immigration-order-chaos.html [http://perma.cc/23ZW-HZBS].

137. Yeganeh Torbati et al., Chaos, Anger as Trump Order Halts Some Muslim Immigrants, REUTERS (Jan. 29, 2017), http://www.reuters.com/article/us-usa-trump-immigration-chaosidUSKBN15COLD [http://perma.cc/Z2SD-2MQ7].

138. Shear \& Nixon, supra note 136.

139. Id.

140. See Peter Nicholas et al., Trump Team Kept Plan for Travel Ban Quiet, WALL ST. J. (Jan. 29, 2017), http://www.wsj.com/articles/trump-team-kept-plan-for-travel-ban-quiet-1485738314 [http://perma.cc/5YNH-YJDP]. 
was signed-contained no legal analysis. ${ }^{141}$ It merely said the Order was "approved with respect to form and legality," 142 which is perhaps best read as stating the Order was validly structured and promulgated, rather than legally sound in substance. ${ }^{143}$ This was Shane's waiving of legal papers in action. Indeed, it seems doubtful that the OLC would have approved the ban's application to legal permanent residents of the United States from the subject countries. Presumably because the ban's application to those permanent residents was clearly unlawful, DHS rushed to exempt them. ${ }^{144}$ In a "highly unusual" move, ${ }^{145}$ the White House counsel issued "Authoritative Guidance" that effectively amended the Order to exclude permanent residents. ${ }^{146}$

Executive Order 13,769 was subsequently enjoined by courts ${ }^{147}$ and then superseded by another Executive Order ${ }^{148}$ (which was itself enjoined and, again, superseded by a third Presidential Proclamation, ${ }^{149}$ which is itself, at printing, subject to an injunction). ${ }^{150}$ The litigation over these Orders has been prolific, ${ }^{151}$

141. Laura Jarrett \& Evan Perez, Internal Memo Shows Travel Ban Approved by DOJ on Friday, CNN (Feb. 2, 2017), http://www.cnn.com/2017/02/02/politics/olc-memorandum-travel-ban [http://perma.cc/4FNN-R2CB].

142. Office of Legal Counsel, Re: Proposed Executive Order Entitled, "Protecting the Nation from Foreign Terrorist Entry into the United States", U.S. DEP'T JUSTICE 2 (Jan. 27, 2017), http://i2.cdn.turner.com/cnn/2017/images/02/02/eo.foreign.terrorist.entry.pdf [http://perma.cc/84G9GTQX]

143. Former Acting Attorney General Sally Yates seem to make this point in recent congressional testimony. See Time, Sally Yates and Ted Cruz Have Heated Exchange over Donald Trump's Travel Ban, YOUTUBE (May 9, 2017), http://www.youtube.com/watch?v=IAD97EW5sz4 [http://perma.cc/M2JA-F3VG]. In any case, this curt OLC opinion offers an interesting point of contrast with the DAPA OLC opinion.

144. Press Release, White House Office of the Press Sec'y, supra note 85; Press Release, White House Office of the Press Sec'y, Dep't of Homeland Sec., Statement by Sec'y John Kelly on the Entry of Lawful Permanent Residents into the United States (Jan. 29, 2017), http://www.dhs.gov/ news/2017/01/29/statement-secretary-john-kelly-entry-lawful-permanent-residents-united-states [http:// perma.cc/J6AH-Q5AD].

145. Josh Gerstein \& Matthew Nussbaum, White House Tweaks Trump's Travel Ban To Exempt Green Card Holders, POLITICO (Feb. 1, 2017), http://www.politico.com/story/2017/02/whitehouse-green-card-holders-no-longer-covered-by-trump-executive-order-234505 [http://perma.cc/TEM5PE7Z].

146. Memorandum from Donald F. McGahn, Counsel to the President, to the Acting Sec'y of State, the Acting Att'y Gen, and the Sec'y of Homeland Sec. (Feb. 1, 2017), http://www.politico.com/f/?id=00000159-fb28-da98-a77d-fb7dba170001 [http://perma.cc/GH8SA2MB].

147. Washington v. Trump, No. C17-0141JLR, 2017 WL 462040 (W.D. Wash. Feb. 3, 2017).

148. Protecting the Nation from Foreign Terrorist Entry into the United States, Exec. Order No. 13,780, 82 Fed. Reg. 13,209 (Mar. 9, 2017).

149. Enhancing Vetting Capabilities and Processes for Detecting Attempted Entry into the United States by Terrorists or Other Public-Safety Threats, Pres. Proclamation No. 9,645, 82 Fed. Reg. 45,161 (Sept. 27, 2017), http://www.gpo.gov/fdsys/pkg/FR-2017-09-27/pdf/2017-20899.pdf [http:// perma.cc/2KRX-N4UA].

150. Hawaii v. Trump, 878 F.3d 662 (9th Cir. 2017) (per curiam). This current injunction is stayed pending appeal to the Supreme Court.

151. See Hawai'i v. Trump, 241 F. Supp. 3d 1119, 1123 n.4 (D. Haw. 2017) (nonexhaustively cataloguing cases); Hawaii v. Trump, 859 F.3d 741, vacated as moot, 874 F.3d 1112 (9th 
but we primarily want to highlight presidentialist-relevant reasoning from earlier cases in this ongoing legal saga. These cases involve now-expired iterations of the travel ban, but they are relevant for our purposes because they demonstrate how courts wrestled with the ban's broad assertion of executive power.

First, the Ninth Circuit's opinion in Washington v. Trump asserted two limits on the president's directive authority. In defending the travel ban, the Justice Department asserted that the President had "unreviewable authority" to enact the ban. ${ }^{152}$ Congress had statutorily delegated discretionary authority to the President to bar "any aliens or any class of aliens" that he "finds . . . would be detrimental to the interests of the United States,"153 and the Justice Department read this determination to be unreviewable. Although the relevant statute delegates authority directly to the President, ${ }^{154}$ the Ninth Circuit sharply disagreed. Even if it owed "substantial deference to the immigration and national security policy determinations of the political branches," the court determined that this act of presidential administration was still reviewable. ${ }^{155}$

In demarcating between reviewable and unreviewable executive immigration actions, the court echoed the reasoning of OLC's DAPA memo. It distinguished the conclusion in Kleindienst $v$. Mandel ${ }^{156}$ that an executive immigration action was unreviewable because "the Mandel standard applies to lawsuits challenging an executive branch official's decision to issue or deny an individual visa based on the application of a congressionally enumerated standard to the particular facts presented by that visa application."157 By contrast, the travel ban was "not about the application of a specifically enumerated congressional policy," but was reviewable as a "promulgation of sweeping immigration policy" and an "exercise[] of policymaking authority at the highest levels of the political branches."158 For the Ninth Circuit Court of Appeals, apparently the more ministerial the executive's immigration actionthat is, the greater degree to which it is premised upon relatively specific statutory standards-the less reviewable. But bolder presidential administration, by virtue of its basis in vague congressional standards (here, the language is the large and loose "detrimental to the interests of the United States"), is subject to more searching judicial review.

This reasoning is questionable, to say the least. In general terms, administrative law doctrine looks in the opposite direction: the broader the

Cir. 2017); Int'l Refugee Assistance Project v. Trump, 857 F.3d 554 (4th Cir. 2017), as amended (May 31, 2017), vacated and remanded, Trump v. Int'l Refugee Assistance Project, 138 S. Ct. 353 (2017).

152. Emergency Motion for Defendant-Appellants at 2, Washington v. Trump, 847 F.3d 1151 (9th Cir. 2017) (No. 17-35105).

153. 8 U.S.C. $\$ 1182(\mathrm{f})(2018)$.

DHS document.

154. This helps explain why the ban was issued as an executive order rather than a

155. Washington v. Trump, 847 F.3d 1151, 1161 (9th Cir. 2017).

156. 408 U.S. 753 (1972).

157. Washington, 847 F.3d at 1162.

158. Id. 
discretion conferred, the less administrative action is subject to judicial review. ${ }^{159}$ The Justice Department was not making a frivolous argument when it claimed that statutory language as vague as "detrimental to the interests of the United States" delegates political judgment to a political branch of the government and that the courts have no workable standard against which to judge whether the President's determination is correct. However, the Justice Department made a further and much less plausible argument that these judgments were not reviewable even for constitutionality. And the Ninth Circuit had no difficulty dispensing with that argument. ${ }^{160}$ The plaintiffs had claimed, among other constitutional violations, that the Trump EO, both in its original incarnation and in its second revised version, was predicated on an intent to discriminate against Muslims in violation of the First Amendment.

Subsequently, the How aii district court enjoined the second Order precisely because it was so directly connected to the President's political statements based in unconstitutional religious animus. In finding that the second Order was intended as the discriminatory "Muslim Ban" that Trump had promised on the campaign trail (and that the second order was not different from the first in this regard), the court catalogued statements from the President and his advisors that strongly supported this finding. ${ }^{161}$ The court argued that "[a]ny reasonable, objective observer would conclude" that "[t]hese plainly-worded statements ... betray the Executive Order's stated secular purpose."162

The Ninth Circuit largely upheld this second injunction. ${ }^{163}$ But notably, it turned away from the lower court's reasoning based on political statements and fraught constitutional questions. Instead, it issued a per curiam opinion based (facially) on more technical statutory interpretation. ${ }^{164}$ That Ninth Circuit shift contrasts sharply with the Fourth Circuit's affirmance of an injunction against the second EO. ${ }^{165}$ Echoing the district court in Hawaii, the Fourth Circuit focused on President Trump's pre- and post-inauguration political statements, as well as statements by those in the President's political orbit, while deciding the case on constitutional grounds. ${ }^{166}$ As the Fourth Circuit explained, "Just as the reasonable observer's 'world is not made brand new every morning,' nor are we

\footnotetext{
159. E.g., Webster v. Doe, 486 U.S. 592, 601 (1988).

160. Washington, 847 F.3d at 1163-64.

161. Hawai'i v. Trump, 241 F. Supp. 3d 1119, 1136-37 (D. Haw. 2017).

162. Id. at 1136 .

163. Hawaii v. Trump, 859 F.3d 741 (9th Cir. 2017).

164. See Leah Litman, See You in Court: Ninth Circuit Round 2, TAKE CARE (June 12, 2017), http://takecareblog.com/blog/see-you-in-court-ninth-circuit-round-2 [http://perma.cc/5P2X75PA]

165. Int'l Refugee Assistance Project v. Trump, 857 F.3d 554 (4th Cir. 2017), as amended (May 31, 2017), vacated and remanded, Trump v. Int'l Refugee Assistance Project, $138 \mathrm{~S}$. Ct. 353 (2017).

166. Id. Judge Thacker argued in a concurrence that the necessary religious purpose could be found if only post-inauguration statements were considered. 857 F.3d at 631-32 (Thacker, J., concurring). See Leah Litman, See You in Court 3.0, TAKE CARE (May 25, 2017), http://takecareblog.com/ blog/see-you-in-court-3-0 [http://perma.cc/6GFU-8X2B].
} 
able to awake without the vivid memory of these [political] statements. We cannot shut our eyes to such evidence when it stares us in the face."167

We should be clear that presidential directives and administrative actions are not invalid simply because politics motivate them. Whatever the merits of the Fourth Circuit and Hawaii district court's conclusions about the political motivations behind the EOs, Professor Strauss is right to call their judicial approach "a remarkable step." 68 So long as officials can give credible explanations of their actions based in statutory authority, that Republican or Democratic administrations arrive at differing policy decisions is irrelevant. The problem with the Trump EOs, as the Ninth Circuit thoroughly described in Washington, was that they simply recited the need to protect against terrorism while offering no evidence or reasoning that connected the ban to realistic safety concerns. ${ }^{169}$ The second Ninth Circuit opinion in Hawaii further cemented this judicial focus on statutorily required evidence and reasoning, rather than campaign rhetoric. To keep electoral promises through presidential administration is not illegal. But the Constitution and statutes constrain what promises can be kept. Congress delegated the power, and it must be exercised for the purposes that motivated the delegation.

If politics in a sense initially undid the Trump executive travel ban, it also seems to have stymied his promise to undo DACA. As Professors Cox and Rodriguez recognized, ${ }^{170}$ the moment Trump took office, he could void the over one-million DACA grants with the stroke of a pen. As a candidate, he promised to do as much. ${ }^{171}$ What's curious is that Trump did not do so for quite some time; in fact, he expressed a hesitancy to eliminate the program. ${ }^{172}$ Initially, his DHS Secretary explicitly left the DACA memo in place, even as he rescinded other

167. Int'l Refugee Assistance Project, 857 F.3d at 599.

168. Strauss, supra note 129 , at 6 . A dissent in the case lambasted this approach. Int' Refugee Assistance Project, 857 F.3d at 649 (Niemeyer, J. et al., dissenting) ("The majority"s new rule, which considers statements made by candidate Trump during the presidential campaign to conclude that the Executive Order does not mean what it says, is fraught with danger and impracticability."). Conservative legal authorities have done the same. E.g., David B. Rivkin Jr. \& Lee A. Casey, The Fourth Circuit Joins the 'Resistance,' WALL ST. J. (May 29, 2017), http://www.wsj.com/articles/the-fourthcircuit-joins-the-resistance-1496071859 [http://perma.cc/9TMB-FKF8].

169. Washington v. Trump, 847 F.3d 1151, 1168 (9th Cir. 2017).

170. See Cox \& Rodriguez, supra note 89 , at 208 ("A single decision of a future administration could reverse the nonenforcement decisions with respect to millions of noncitizens.").

171. Cindy Carcamo, Beneficiaries of Obama's Immigration Relief Worry About Future Under Trump, L.A. TIMES (Nov. 13, 2016), http://www.latimes.com/local/california/la-ma-dacarecipients-face-uncertain-future-20161110-story.html [http://perma.cc/2KF7-ZG85]; Nick Gass, Trump Rips Obama, Clinton After Supreme Court Immigration Decision, POLITICO (June 23, 2016), http://www.politico.com/story/2016/06/trump-immigration-supreme-court-224736 [http://perma.cc/ Z4AY-AEVY].

172. Transcript of AP interview with Trump, Associated PRESS (Apr. 23, 2017), http://www.apnews.com/c810d7de280a47e88848b0ac74690c83 [http://perma.cc/8HMW-HHCC] (reporting Trump's statement that "[t]he dreamers should rest easy"); Mark Hensch, Steve King 'Very Disappointed' by Trump's Inaction on DACA, HILL (Apr. 14, 2017), http://thehill.com/homenews /administration/328890-steve-king-very-disappointed-by-trump-on-amnesty [http://perma.cc/53NLXVSC]. 
Obama-era immigration guidance. ${ }^{173}$ For months, the situation was day-today, ${ }^{174}$ and Attorney General Sessions expressed a willingness to deport DACA beneficiaries and to potentially end the program altogether. ${ }^{175}$ It may be that Trump initially wished to avoid the political liability of full-on DACA elimination, which would bring brutal scenes of children, teenagers, and young adults being deported to countries they may not even remember.

Even after Trump decided to end DACA (with Attorney General Sessions announcing the decision), ${ }^{176}$ Trump has struggled politically with eliminating it (and even implied that he would somehow retain DACA if Congress failed to codify its protections into law). ${ }^{177}$ At writing, it remains uncertain if Congress or the President will act.

By contrast, the Trump Administration managed, within just a year, to effect a rapid, massive ramp-up of immigration enforcement. Indeed, this enforcement ramp-up may be one of the Administration's biggest successes in terms of accomplishing its stated policy goals. This reorientation began with two other Executive Orders on immigration, ${ }^{178}$ both of which the DHS Secretary has interpreted and operationalized in subsequent guidance. ${ }^{179}$ These Orders and

173. Memorandum from John Kelly, Sec'y, Dep't of Homeland Sec., to Kevin McAleenan, Acting Comm., USCBP, et al. 2 (Feb. 20, 2017), http://www.dhs.gov/ sites/default/files/publications/17_0220_S1_Enforcement-of-the-Immigration-Laws-to-Serve-theNational-Interest.pdf [http://perma.cc/EEA8-LFGW] [hereinafter Kelly Memo 1]; see also Ted Hesson \& Seung Min Kim, Wary Democrats Look to Kelly for Answers on Immigration, PoLITICo (Mar. 29, 2017), http://www.politico.com/story/2017/03/wary-dems-look-to-kelly-for-answers-on-immigration-236673 [http://perma.cc/9YQP-4CGF] ("Of the DACA program, Kelly said both the government and individuals have an obligation to honor the terms of the policy. "The DACA status is a commitment, not only by the government towards the DACA person, or the so-called Dreamer, but by that person to obey the law, Kelly said.").

174. Ted Hesson, DACA Still 'Under Review,' Trump Administration Says, PoLITICo (June 16, 2017), http:/www.politico.com/story/2017/06/16/trump-daca-immigration-deportation-reliefprogram-239654 [http://perma.cc/SMK7-SR5G]; Ted Hesson, Kelly Won't Commit To Defending DACA in Court, POLITICO (July 12, 2017), http:/www,politico.com/story/2017/07/12/john-kelly-daca-legalchallenge-240470 [http://perma.cc/HP8A-QMMB].

175. Michael Tan, Are States Coordinating With the Trump Administration To Take Down DACA? We Aim To Find Out, AM. CIVIL LIBERTIES UNION (Aug. 7, 2017), http://www.aclu.org/ blog/speak-freely/are-states-coordinating-trump-admin istration-take-down-daca-we-aim-find-out [http://perma.cc/9GAS-EQQC] Ted Hesson, Sessions: 'We Can't Promise' DREAMers Won't Be Deported, POLITICo (Apr. 19, 2017), http://www.politico.com/story/2017/04/jeff-sessions-dreamsdeported-237369 [http://perma.cc/BM2H-83AG].

176. Letter from Jefferson B. Sessions III, Att'y Gen., Dep't of Justice, to Elaine Duke, Acting Sec'y, Dep't of Homeland Sec. (Sept. 5, 2017), http://www.justice.gov/opa/speech/file/994651/ download [http://perma.cc/2U7F-2MX3].

177. Sophie Tatum, Trump: I'll 'Revisit' DACA If Congress Can 't Fix in 6 Months, CNN (Sept. 6, 2017), http://www.cnn.com/2017/09/05/politics/donald-trump-revisit-daca/index.html [http:// perma.cc/JUB3-J43D].

178. Enhancing Public Safety in the Interior of the United States, Exec. Order No. 13,768, 82 Fed. Reg. 8,799 (Jan. 30, 2017); Border Security and Immigration Enforcement, Exec. Order No. 13,767, 82 Fed. Reg. 8,793 (Jan. 30, 2017).

179. Kelly Memo 1, supra note 173; Memorandum from John Kelly, Sec'y, Dep't of Homeland Sec., to Kevin McAleenan, Acting Comm., USCBP, et al. (Feb. 20, 2017), http://www.dhs.gov /sites/default/files/publications/17 0220_S1_Enforcement-of-the-Immigration-Laws-to-Serve-theNational-Interest.pdf [http://perma.cc/NH7S-A7V2]. 
agency guidance, among other changes, vastly expand the number of undocumented immigrants who are deemed deportation priorities; begin a hiring surge of 15,000 immigration and border patrol agents; expand cooperation with local and state law enforcement to assist in immigration enforcement; and increase the use of so-called "expedited removal," which provides for deportation without a hearing before an immigration judge. ${ }^{180}$ The Trump Administration has also pulled back on grants of temporary legal status to groups of Haitian $^{181}$ and El Salvadorian immigrants, ${ }^{182}$ among others.

While the travel ban was initially mired in litigation, these operational changes began with relatively little legal challenge. To anyone watching, the tenor and aggressiveness of immigration enforcement has immediately changed. Enforcement statistics are reflecting this shift. ${ }^{183}$ Moreover, immigration patterns across the southern border seem to be responding to Trump's rhetorical and operational shifts. $^{184}$

In the abstract, one would assume that Obama would have had an easier time implementing non-enforcement than Trump would have ratcheting up enforcement, especially since non-enforcement is far less susceptible to judicial review. But to date, the opposite has been the case.

So why has the enforcement ramp-up been so successful? First, these changes are much less visible than the travel ban. They involve operational

180. See Camila Domonoske, What's New in Those DHS Memos on Immigration Enforcement?, NPR (Feb. 22, 2017), http://www.npr.org/sections/thetwo-way/2017/02/22/516649344/ whats-new-in-those-dhs-memos-on-immigration-enforcement [http://perma.cc/PPK5-QZNR]. On the use of expedited removal by the Trump administration, see Jill E. Family, Due Process Sleight of Hand, YALE J. ON REG.: NOTICE \& COMMENT (Feb. 21, 2017), http://yalejreg.com/nc/due-process-sleight-of-hand-byjill-e-family/ [http://perma.cc/H93C-45QA].

181. Miriam Jordan, Trump Administration Ends Temporary Protection for Haitians, N.Y. TIMES (Nov. 20, 2017), http://www.nytimes.com/2017/11/20/us/haitians-temporary-status.html [http://perma.cc/W5DK-UPPU].

182. Miriam Jordan, Trump Administration Says that Nearly 200,000 El Salvadorians Must Leave, N.Y. TIMES (Jan. 8, 2018), http://www.nytimes.com/2018/01/08/us/salvadorans-tpsend.html [http://perma.cc/NF39-WW5V].

183. Agency Release, Immigration \& Customs Enf't, ICE ERO Immigration Arrests Climb Nearly 40\% (Nov. 2, 2017), http://www.ice.gov/features/100-days [http://perma.cc/7R54-JJ2C]; Press Release, Dep't of Justice Office of Pub. Affairs, Return to Rule of Law in Trump Administration Marked by Increase in Key Immigration Statistics (Aug. 8, 2017), http://www.justice.gov/opa/pr/returnrule-law-trump-administration-marked-increase-key-immigration-statistics [http://perma.cc/932G7FM8]; Caitlin Dickerson, Immigration Arrests Rise Sharply as a Trump Mandate Is Carried Out, N.Y. TIMES (May, 17, 2017), http://www.nytimes.com/2017/05/17/us/immigration-enforcement-icearrests.html [http://perma.cc/G3SE-EN4W]; Geneva Sands, Immigration-Related Arrests by ICE Increase Under President Trump, ABCNEws (Apr. 17, 2017), http://abcnews.go.com/US/immigration-relatedarrests-ice-increase-president-trump/story?id=46847044 [http://perma.cc/SB8Q-HN7A].

184. See Nick Miroff, Arrests Along Mexico Border Drop Sharply Under Trump, New Statistics Show, WASH. POST (Dec. 5, 2017), http://www.washingtonpost.com/world/national-security/ arrests-along-mexico-border-drop-sharply-under-trump-new-statistics-show/2017/12/05/743c6b54d9c7-11e7-b859-fb0995360725_story.html [http:/perma.cc/DA2R-SXC9]; David Nakamura, Amid Immigration Setbacks, One Trump Strategy Seems To Be Working: Fear, WASH. POST (Apr. 30, 2017), $\mathrm{http}$ ://www.washing tonpost.com/politics/amid-immigration-setbacks-one-trump-strategy-seems-to-beworking-fear/2017/04/30/62afl620-2b4e-11e7-a616-d7c8a68cla66_story.html [http://perma.cc/66WKSS8L]. 
policy choices that are, generally speaking, far less susceptible to judicial review. ${ }^{185}$ They do not change anyone's legal status, and some, like the hiring surge, seem to be routine managerial decisions. To be sure, expedited removal may be challenged in individual cases, but whether any due process or statutory procedural rights have been infringed will depend on the particular circumstances surrounding those cases.

Second, these enforcement initiatives seem aligned with general policy preferences up and down the immigration and homeland security bureaucracy, from the President's top political appointees to line officers. To begin at the top, Trump has appointed immigration hardliners who have zealously implemented his immigration agenda_particularly Attorney General Jeff Sessions. In turn, Attorney General Sessions has considerable authority over the immigration judges who hear deportation cases. This operational authority limits the degree to which resistance might emerge in individual administrative proceedings. ${ }^{186}$

Moving down the chain of command, civil servants in the immigration enforcement bureaucracy seem to be, generally speaking, sympathetic to these enforcement policies. During the election, the union for ICE employees endorsed Trump-the first endorsement the union has ever made. ${ }^{187}$ By contrast, the Obama Administration struggled to temper immigration enforcement at first, at least in part because Obama's more lenient enforcement policies cut against the policy preferences of the immigration bureaucracy. ${ }^{188}$ ICE employees themselves sued to invalidate DACA. ${ }^{189}$ Presidential administration starts at the top, and the Sessions appointment illustrates the strong association between effective presidential administration and the President's power to appoint highlevel administrative officials. But Trump's enforcement ramp-up also shows how the views and sympathies of the civil service can have a major impact on the speed and efficacy of implementation.

\section{Preliminary Thoughts on Immigration Presidentialism}

Viewing these successes and failures of the Obama and nascent Trump Administrations under the presidentialist lens, a few key points come into focus. First, Shane's "one-way ratchet" seems to be working to propel the ever more

185. See Norton v. S. Utah Wilderness All., 542 U.S. 55, 61-67 (2004) (finding agency discretion as to "broad, programmatic" policy choices to be generally unreviewable under the APA).

186. See Jill E. Family, Beyond Decisional Independence: Uncovering Contributors to the Immigration Adjudication Crisis, 59 KAN. L. REV. 541, 542-44 (2011).

187. ICE Union Endorses Trump, POLITiCo (Sept. 26, 2016), http://www.politico.com/ story/2016/09/immigration-customs-enforcement-union-endorses-trump-228664 [http://perma.cc/ D9KW-SGQZ]

188. See Cox \& Rodriguez, supra note 89, at 191-92 (describing ICE agents as "extremely resistant" to pre-DACA/DAPA policy guidance from the Obama Administration, with "discontent [that] ultimately bubbled up through the employees" union").

189. See supra note 92 . 
prevalent use of presidential directive authority. ${ }^{190}$ The boldness of presidential assertions of power have even begun to trouble even strong unitarian theorists like Professor John Yoo. ${ }^{191}$ It seems almost quaint that, fifteen years ago, Kagan made waves by advocating strong presidential directive authority. Indeed, the general public-influenced, to be sure, by the way the press reports administrative actions - now seems to assume an identity between the President and administration. The Democratic health plan was Obamacare, even if the Obama Administration left much of the ACA's substance to be ironed out by its legislative sponsors; the ill-fated Republican health plan is Trumpcare, even if Trump had little interest in the legislation's details. The public may not only assume presidentialism, but demand it. Both political parties claim executive overreach when the other controls the White House, but either side's political base would likely be furious if its President refused to assertively direct and control administration.

Second, even as this presidential mode is ascendant, both Obama and Trump encountered some legal anxiety over ever-stronger presidential administration. Both the DAPA OLC opinion and the federal courts in the Texas, Hawaii, and Washington judicial opinions refused to give either administration unchecked power to unilaterally implement sweeping policy when that policy was not sufficiently tethered to congressional priorities, as embodied in statute. These exercises of presidential authority are becoming so massive that judges are willing, at least to a certain extent, to overcome presumptions of nonreviewability of executive enforcement policies and extreme deference to executive judgments concerning national security. DAPA was easily characterized as a discretionary non-enforcement decision that is normally unreviewable. Recharacterizing it as a rule was a relatively aggressive exercise of judicial review, as was the invalidation of Trump's travel ban based on motivation evidenced by campaign statements. How much separation of powers, as enforced by an independent judiciary, will limit Trump Administration policymaking remains to be seen.

One also sees contrasts among various immigration initiatives in the relative attention to process and established administrative norms and institutions. One would expect some correlation between process and policy durability, ${ }^{192}$ and indeed, the travel ban's failed rollout seems like it was largely a function of inadequate process (legally. as well as politically). ${ }^{193}$ Shane

190. See SHANE, supra note 48 , at 4 .

191. John Yoo, Executive Power Run Amok, N.Y. TIMES (Feb. 6, 2017), http:// www.nytimes.com/2017/02/06/opinion/executive-power-run-amok.html [http://perma.cc/78DR-66PF].

192. Cf. Chen, supra note 188 , at 352 ("Without discounting the importance of political accountability, this Article suggests that perfecting procedure is an important component of the expertise that legitimates agency action.").

193. Both the Fourth and Ninth Circuits referenced process issues in upholding injunctions against the ban. Hawaii v. Trump, No. 17-15589, 859 F.3d 741, 756 (9th Cir. 2017) (noting the first EO was promulgated "without interagency review"); Int'l Refugee Assistance Project v. Trump, 857 F.3d 554, 596 (4th Cir. 2017), as amended (May 31, 2017) ("The Government's argument that EO- 
bemoans the empty formalism of executive legal process and authority for presidentialism, but the travel ban experience to date shows that internal executive legal processes can mean something. We are doubtful that the Trump Executive Orders would have emerged in the form that they did had there been serious involvement from OLC. But process and professionally competent lawyering are not magic shields against legal invalidation. Obama tried to rationalize his extensions of executive power in DAPA through heavy attention to legal processes and norms, ${ }^{194}$ but that ultimately failed to save the policy.

As a separation-of-powers matter, both Trump and Obama's major immigration actions have been unilateral, despite the unified government under Trump (and divided one under Obama). In the separation-of-parties model, one might expect Trump to request that a Republican Congress revamp immigration policy legislatively to make his changes more enduring. (That may change to a certain degree if a DACA deal is consummated, but that would be more the exception than the rule.) But Congress is a sluggish institution at best. And many congressional Republicans, as shown by their voting records, are supportive of more centrist immigration reform. Under the current Congress, if Trump's overarching immigration policies were embodied in legislation, we doubt they would pass. ${ }^{195}$ There are policy disagreements beneath the sharp partisanship in D.C. and those disagreements manifest themselves institutionally. A Democratic Congress may not have been able to counter Trump's immigration initiatives effectively, but a Republican Congress is not lending strong support. Separation of powers retains some operational meaning, notwithstanding unified government.

Finally, the Obama and Trump experiences with respect to immigration policy also have something to say about appropriation and accountability. Undoubtedly, both Presidents "owned" their executive actions in some sense. As evidenced in judicial opinions striking down both DAPA and the travel ban, we have even seen the potential legal downside of "appropriation," the possibility that administrative action will be judged based on how the President portrays the policy in his political appropriation of it, both before and after implementation. ${ }^{196}$

On the other hand, ownership or appropriation, at least in Kagan's sense, does not always translate straightforwardly into electoral accountability. Obama

2's primary purpose is related to national security ... is belied by evidence in the record that President Trump issued the First Executive Order without consulting the relevant national security agencies ...."), vacated and remanded, Trump v. Int'l Refugee Assistance, 138 S. Ct. 353 (2017).

194. SAVAGE, supra note 60 , at 661 .

195. Some limited, Trumpian immigration bills have at least passed the House, however. See Emmarie Huetteman \& Nicholas Kulish, House Passes 2 Strict Immigration Bills, at Trump's Urging, N.Y. TIMES (June 29, 2017), http://www.nytimes.com/2017/06/29/us/politics/housepasses-strict-immigration-bills-at-trumps-urging.html [http://perma.cc/ZQB5-L38G].

196. E.g., Matt Zapotosky, Judges Take Trump at His Word-and That's Not Been Good for the President, WASH. POST (Apr. 28, 2017), http://www.washingtonpost.com/world/nationalsecurity/judges-take-trump-at-his-word--and-thats-not-been-good-for-the-president/2017/04/28/ 9c222444-2b7e-11e7-a616-d7c8a68c1a66_story.html [http://perma.cc/X4TG-XMH2]. 
announced DACA before the 2012 election presumably because it was to his advantage, and he seemingly delayed DAPA in a failed attempt to improve his party's electoral chances in the subsequent political cycle. Currying favor with particular constituencies and avoiding political backlash are in some sense tied to electoral accountability. But neither has the democracy-reinforcing resonance that permeates Kagan's normative case for presidentialism.

Kagan's view of the positive accountability role of presidential media coverage has also proved to be too optimistic. This stems in part from the development of hyper-partisan media outlets. President Trump's first one hundred days have been a failure or a success depending on which press outlets are consulted. And President Obama was a courageous and progressive leader or a scofflaw in his immigration actions in much the same way. Shane's more skeptical, pluralist view of the political media is undoubtedly the more accurate one. Politics has always been blood sport, but when Kagan wrote her apologia, norms of presidential transparency and press political neutrality were, in many senses, far stronger. Those norms seem necessary to the proper functioning of presidential accountability mechanisms. ${ }^{197}$ In terms of twenty-first century media and democratic accountability, one wonders if Kagan had been able, in 2001 , to "read / the book of fate, / And see the revolution of the times . . ,,"198 whether she would be quite so dismissive of Madisonian concerns over executive power. ${ }^{199}$

\section{B. Climate Change}

Climate change is another policy area that, for the Obama and early Trump presidencies, has been largely defined through presidential administration. Chiefly in the second half of his presidency, President Obama attempted to address climate change through a sweeping set of executive actions, and the Trump Administration's push to roll back those actions has been intense and rapid.

\section{Obama: The CPP \& the Paris Agreement}

In his first term, President Obama made an abortive push for congressional action on climate change, with the failed "Waxman-Markey" cap-and-trade bill to limit domestic greenhouse gas emissions. ${ }^{200}$ Legislative action subsequently

197. This would also apply to congressional accountability. Pluralism is generally on shaky ground if we are truly in an era of post-truth politics.

198. WILliam Shakespeare, The SECOND PART OF KING HENRY THE FourTh act 3 , sc. 1 .

199. Kagan, supra note 21 , at 2345-46.

200. H.R. 2454, 111 th Cong. (2009); see also JONATHAN CHAIT, AUDACITY: How BARACK OBAMA DEFIED His CRITICS AND CREATED A LEGACY THAT WILL PREVAIL 120-24 (2017). For a brief description of the Waxman-Markey and its merits, see Rachel Brewster, Stepping Stone or 
became impossible, given the opposition of Democrats in oil and coal-heavy states, as well as increasingly widespread climate change denial within the GOP. In the years after that legislative failure, the Obama Administration crafted an audacious executive agenda to combat climate change. That agenda included domestic regulatory efforts to curb emissions from power plants and vehicles; international negotiations on emissions limits; and efforts to order the operation of the federal government to account for climate change-from budgetary requests and environmental planning to cost-benefit analysis in rulemaking. ${ }^{201} \mathrm{~A}$ full account of these efforts is beyond this Article's scope. This Section will focus solely on President Obama's signature domestic regulatory action on climate - the Clean Power Plan-and his signature international achievementthe Paris Agreement.

The Clean Power Plan (CPP) was a bold attempt to use EPA authority under the Clean Air Act to substantially reduce carbon emissions from existing power plant infrastructure. ${ }^{202}$ Electricity generation from power plants produces around thirty percent of U.S. carbon emissions, ${ }^{203}$ which is why the CPP was central to the Obama climate strategy. ${ }^{204}$ The CPP set national targets for improved carbon efficiency of power generation, starting in 2022, and requiring the attainment of final efficiency goals by $2030 .^{205}$ Based on these national targets, the EPA devised state-level efficiency targets, and under the CPP, each state would be required to formulate a plan to meet its target. ${ }^{206}$ The EPA projected a thirty-two percent reduction in $\mathrm{CO}_{2}$ emissions from electricity generation if, through stateby-state effort, these national goals were met. $^{207}$

Stumbling Block: Incrementalism and National Climate Change Legislation, 28 YALE L. \& POL'Y REV. 245, 284-92 (2010).

201. For a superb description of these efforts, with a focus on the last category, see Yumehiko Hoshijima, Note, Presidential Administration and the Durability of Climate-Consciousness, 127 YALE L.J. 170 (2017).

202. Carbon Pollution Emission Guidelines for Existing Stationary Sources: Electric Utility Generating Units, 80 Fed. Reg. 64,662, 64,663 (Oct. 23, 2015)

203. Inventory of U.S. Greenhouse Gas Emissions and Sinks: 1990-2014, ENVTL. PROT. AGENCY 2-22 (Apr. 15, 2016), http://www.epa.gov/sites/production/files/2016-04/documents/us-ghginventory-2016-main-text.pdf [http://perma.cc/Y8P4-943C]

204. President Obama undertook complementary efforts to curb emissions from new power plants and non-stationary sources. On new power plants, see Standards of Performance for Greenhouse Gas Emissions From New, Modified, and Reconstructed Stationary Sources: Electric Utility Generating Units, 80 Fed. Reg. 64,510 (Oct. 23, 2015), http://www.gpo.gov/fdsys/pkg/FR-2015-10 23/pdf/2015-22837.pdf [http://perma.cc/GUN9-7QXH]. The Obama Administration promulgated various fuel efficiency rules for different vehicle types, but for a compelling description of how the Administration promulgated its initial fuel economy standards for cars and light trucks, see Jody Freeman, The Obama Administration's National Auto Policy: Lessons from the "Car Deal," 35 HARV. ENVTL. L. REV. 343 (2011).

205. JAMES E. MCCARTHY ET AL., CONG. RES. SERV., R44341, EPA's ClEAN POWER PLAN FOR EXISTING POWER PLANTS: FREQUENTLY ASKED QUESTIONS 15 tbl.1 (2016).

206. Id. at 17-18 tbl.2.

207. Id. at 12 . 
The CPP was notable for the flexibility it provided states in how they could work to comply with the emissions targets over a long time horizon. ${ }^{208}$ While the EPA provided what it called "building blocks" of carbon efficiency to calculate its goals, states would be free to formulate their own strategies to meet the EPA's performance standards. ${ }^{209}$ The final CPP also allowed states to trade emissions allowances among themselves. ${ }^{210}$

The CPP began to take its earliest shape in 2013, when the Obama White House released its "Climate Action Plan,"211 a document that broadly described the White House's overall vision for climate policy, from emissions reduction to infrastructure resiliency. In the Action Plan, the first listed priority for emissions reduction was power plant emissions. ${ }^{212}$ As anticipated by the Action Plan, President Obama published a classically Clintonian presidential directive that ordered the EPA Administrator to promulgate what would become the CPP. ${ }^{213}$ In that directive, the President provided high-level policy guidance that foreshadowed the flexible, state-centric, performance-based nature of the finalized CPP. ${ }^{214}$

Intense legal fighting over the CPP's validity began soon after it was promulgated in late 2015. The Republican-controlled Senate attempted to use the Congressional Review Act-a congressional tool for voiding newly promulgated regulations that is discussed infr $\mathrm{a}^{215}$ - to invalidate the CPP, but Obama vetoed that effort. ${ }^{216}$ Numerous states and other litigants sued in the D.C. Circuit to invalidate the CPP on various environmental and administrative law grounds, with those cases consolidated into West Virginia $v . E P A{ }^{217}$ That years-long legal battle was still unresolved at the end of the Obama Administration. However, early in the West Virginia case, the petitioners appealed to the Supreme Court for a preliminary injunction of the CPP while the litigation continued. In an

208. CHAIT, supra note 200 , at $128-30$

209. MCCARTHY ET AL., supra note 205, at 15.

210. Robert Sussman, Obama's Final Clean Power Plan: Merging Strong Climate Goals with Flexible Implementation, BROOKINGS INST.: PLANET POLICY (Aug. 4, 2015), http:/www.brookings.edu/blog/ planetpolicy/2015/08/04/obamas-final-clean-power-plan-merging-strong-climate-goals-with-flexibleimplementation [http://perma.cc/8PNK-A5XG].

211. EXEC. OFF. OF THE PRESIDENT, The PREsident's Climate ACTION Plan (June 2013), http://obamawhitehouse.archives.gov/sites/default/files/image/president27sclimateactionplan.pdf [http://perma.cc/K4WR-BX28]

212. Id. at 6 .

213. Power Sector Carbon Pollution Standards, 78 Fed. Reg. 39,535, 39,535-36 § 1(b) (July 1, 2013), http://www.gpo.gov/fdsys/pkg/FR-2013-07-01/pdf/2013-15941.pdf [http://perma.cc/ 4TAJ-HPV9]

214. Id. $\$ 1(\mathrm{c})$.

215. See infra Section IV.C.2.

216. Memorandum of Disapproval on S.J. Res. 24, The White House (Dec. 18, 2015), http://obamawhitehouse.archives.gov/the-press-office/2015/12/19/memorandum-disapproval-sj-res-24 [http://perma.cc/R46U-PN2V].

217. West Virginia v. EPA, (No. 15-01363) (D.C. Cir. Oct. 23, 2015). See generally

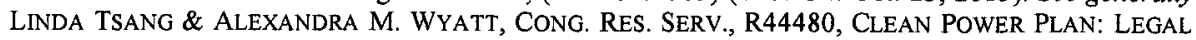
BACKGROUND AND PENDING LITIGATION IN WEST VIRGINLA V. EPA (Mar. 8, 2017). 
"unprecedented" move, ${ }^{218}$ the Court granted the stay, in a 5-4 vote. ${ }^{219}$ The Supreme Court "had never before granted a request to halt a regulation before review by a federal appeals court." 220 The obvious conclusion was that five Justices were already predisposed to invalidate the CPP, even before the D.C. Circuit had ruled. When Justice Scalia passed away just days after voting for the CPP stay, ${ }^{221}$ it soon became clear that the next President would pick the Supreme Court Justice who could effectively decide the case.

We will return to the CPP's fate when we discuss President Trump's climate policy, but for now, we turn to the signature international achievement of Obama's climate agenda: the Paris Agreement. ${ }^{222}$ The Paris Agreement was finalized in late 2015, when 196 countries accepted the Agreement's core goal: to "[h]old[] the increase in the global average temperature to well below $2^{\circ} \mathrm{C}$ above pre-industrial levels and pursu[e] efforts to limit the temperature increase to $1.5^{\circ} \mathrm{C}$ above pre-industrial levels." ${ }^{.223}$ To achieve this goal, the Paris Agreement 'adopt[ed] a 'bottom-up' framework, meaning that all parties independently determine how much they will reduce their greenhouse gas emissions." 224 The Paris Agreement is like an international version of the CPP. But whereas the EPA set binding efficiency targets for American states, nationstates under the Paris Agreement decided their own emissions targets"Intended Nationally Determined Contributions (INDCs)"225 - in light of that global $2^{\circ} \mathrm{C}$ performance goal. These INDCs would not be "legally binding" under the Agreement, but nations would be bound "to report their commitments and steps taken toward[] implementation."226 The CPP was the centerpiece of Obama's plan to achieve the United States' INDC toward the Paris Agreement's warming limit.

While Obama oriented U.S. climate policy toward the Paris Agreement's goals, the Agreement "states no legally binding emissions caps, declaring only that member states "should' meet such targets," while "those relatively few 'legally binding provisions [included in the Paris Agreement] are largely

218. Adam Liptak \& Coral Davenport, Supreme Court Deals Blow to Obama's Efforts To Regulate Coal Emissions, N.Y. TIMES (Feb. 9, 2016), http://www.nytimes.com/2016/02/10/us/politics/ supreme-court-blocks-obama-epa-coal-emissions-regulations.html [http://perma.cc/WE8X-3QD5]

219. Order in Pending Case, West Virginia v. EPA, 136 S. Ct. 1000 (2016) (mem.).

220. Liptak \& Davenport, supra note 218.

221. And Senate Republicans declined to provide a hearing for any appointee that President put forward.

222. Paris Agreement, Dec. 12, 2015, T.I.A.S. No. 16-1104, http://unfecc.int/files/ essential_background/convention/application/pdf/english_paris_agreement.pdf [http://perma.cc/D7KQ79YV].

223. Id. $\$ 1(\mathrm{a})$.

224. United States Joins Consensus on Paris Climate Agreement, 110 AM. J. INT'L L. 374, 374 (2016) [hereinafter United States Joins].

225. Id. at 375 .

226. Id. at 374; see also Paris Agreement, supra note 222, at $\$ 4.2$ ("Each Party shall prepare, communicate and maintain successive nationally determined contributions that it intends to achieve." (emphasis added)). 
procedural in nature and in many instances are duplicative of existing U.S. obligations under the UN Framework Convention on Climate Change,",227 a treaty the U.S. Senate ratified in 1992.

The Obama Administration needed this legal combination in the Paris Agreement-nonbinding commitments that Obama could implement domestically pursuant to his existing regulatory authority, along with binding commitments based in existing treaty law-to allow him to accede to the treaty unilaterally, without congressional approval. ${ }^{228}$ At the time of its adoption, the Paris Agreement could not, as a political matter, pass the Senate as a treaty (or the House and Senate as a congressional-executive agreement). ${ }^{229}$ Thus, while negotiating in Paris, "as a matter of U.S. law, the administration sought an executive agreement," which the President can make unilaterally, "rather than an Article II treaty." 230 According to Professor Harold Koh, the Paris Agreement was a lawful act of purely presidential administration-despite its epochal importance-because, in part, America's commitments (binding and nonbinding) were reflected in "preexisting domestic legal obligations," including a prior Article II treaty. ${ }^{231}$

As Professor Jack Goldsmith has written, the Paris Agreement was emblematic of "the Obama administration's defining legacy" in international lawmaking ${ }^{232}$ : a "cobbling together [of] tools that significantly expanded the President's power to make international agreements without Congress' consent, and sometimes in the face of clear congressional opposition."233 The Paris Agreement was presidentialism in international law-bold and aggressive executive action in the face of congressional gridlock. Obama was historically unsuccessful at securing congressional approval of treaties, ${ }^{234}$ so he pulled

227. Harold Hongju Koh, Triptych's End: A Better Framework To Evaluate 21st Century International Lawmaking, 126 YALE L.J.F. 338, 352 (2017) (quoting Michael J. Mattler, Observations on Recent U.S. Practice Involving Treaties and Other International Agreements and Arrangements 2 (Oct. 15, 2016) (unpublished paper presented at 2016 Yale-Duke Foreign Relations Law Roundtable)).

228. United States Joins, supra note 224, at 377-78 ("[T] limit the legal obligations in the Paris Agreement in part to avoid the need for ex post approval by the Senate or Congress as a whole."); Karoun Demirjian \& Steven Mufson, Trick or Treaty? The Legal Question Hanging over the Paris Climate Change Conference, WASH. POST (Nov. 30, 2015), http:/www.washingtonpost.com/news/powerpost/wp/2015/11/30/trick-or-treaty-the-legalquestion-hanging-over-the-paris-climate-change-conference [http://perma.cc/2D2M-3SZB].

229. Jack Goldsmith, The Contributions of the Obama Administration to the Practice and Theory of International Law, 57 HARV. INT'L L.J. 455, 464 (2016) ("President Obama knew from the outset that two-thirds of the Senators would not consent to . . . the Paris Agreement.").

230. United States Joins, supra note 224, at 381. But see Koh, supra note 227 (arguing that the tripartite legal framework for U.S. international agreements-treaty, congressional-executive agreement, and executive agreement-should be de-emphasized for a more substantive, contextual inquiry into the President's legal authority to enter into international agreements).

231. Koh, supra note 227, at 352.

232. Goldsmith, supra note 229 , at 463.

233. Id. at 456. Obama's other key international agreement that fits this description is the Iran Nuclear Deal.

234. Id. at 464 
together various bases of executive authority-rulemaking power under the Clean Air Act, existing U.S. treaty obligations, etc. - to construct an international climate agreement that circumvented Congress. ${ }^{235}$ As Professor Goldsmith notes, the two prongs of this strategy are entirely normal when employed separately. Presidents often unilaterally make international political commitments and unilaterally exercise domestic policy authority. But in the Paris Agreement, "[w] hat was innovative was bringing the two prongs together in one initiative to forge deep international cooperation supported by significant changes in U.S. domestic law without recourse to a congressional vote."236 Through that alchemy of presidential administration, Obama constructed an international climate policy that was unachievable through conventional means.

\section{Trump: De-Decarbonization}

Political commentator Jonathan Chait wrote as Trump took office, "if there was a single aspect of Obama's legacy most vulnerable to reversal, it was his achievements on climate change."237 To examine that vulnerability, this Article discusses Trump's approach to the CPP and then his relationship with the Paris Agreement.

To reorient domestic climate policy, President Trump has employed three key strategies: appointments, directive authority, and appropriations. The first two strategies have been quite successful, while Congress initially rebuffed his attempt to reorient climate-related appropriations (at least through one budget cycle).

To begin with appointments, Trump essentially ended Obama's regulatory efforts to contain carbon emissions with one appointment: Scott Pruitt as EPA Administrator. Scott Pruitt largely denies anthropogenic climate change and fervently opposes Obama's climate policies. ${ }^{238}$ So far, Pruitt has zealously implemented Trump's deregulatory climate agenda and suppressed government science on climate threats. ${ }^{239}$

With that dutiful appointee in place, Trump sought to undo most of Obama's major domestic climate policy through a single Executive Order. ${ }^{240}$ The

235. Id. at 466 ("The Obama team's imaginative answer to this conundrum was to locate the authority to fulfill the political commitments in independent domestic law authorities that were not designed to effectuate or approve international agreements.").

236. Id. at 467.

237. CHATT, supra note 200 , at 139.

238. Brady Dennis \& Chris Mooney, On Climate Change, Scott Pruitt Causes an Uproar-and Contradicts the EPA's Own Website, WASH. POST (Mar. 9, 2017), http:// www.washingtonpost.com/news/energy-environment/wp/2017/03/09/on-climate-change-scott-pruittcontradicts-the-epas-own-website [http://perma.cc/5J4R-W6G4].

239. See Coral Davenport, Counseled by Industry, Not Staff, E.P.A. Chief Is Off to a Blazing Start, N.Y. TIMES (July 1, 2017), http://www.nytimes.com/2017/07/01/us/politics/trump-epachief-pruitt-regulations-climate-change.html [http://perma.cc/8262-VPPQ]; infra notes 329-330.

240. Promoting Energy Independence and Economic Growth, Exec. Order No. 13,783, 82 Fed. Reg. 16,093 (Mar. 31, 2017). 
EO directed Administrator Pruitt to "as soon as practicable, suspend, revise, or rescind" the CPP. ${ }^{241}$ Within days, Pruitt announced his review of the CPP in accordance with the EO. ${ }^{242}$ Meanwhile in the West Virginia litigation challenging EPA's implementation of the CPP, the D.C. Circuit granted the EPA's requested two-month suspension of the case. ${ }^{243}$ This was widely seen as a prelude to the withdrawal of the EPA's rule, ${ }^{244}$ and the EPA proposed repeal of the CPP in October 2017. ${ }^{245}$ The DC Circuit had already heard oral argument in the case, and a ruling seemed imminent. Pro-CPP litigants seem to be mulling various legal strategies to force a ruling, block CPP rescission, or force some type of EPA carbon plan, ${ }^{246}$ while the EPA and anti-CPP parties pursue the opposite course. ${ }^{247}$ Post-CPP litigation could thus indicate how successful (or unsuccessful) pro-regulatory litigants can be in blocking rescissions and forcing regulation by the Trump Administration. The administration has already been stymied in its attempt to delay the effective date of an Obama-era regulation without going through the necessary notice-and-comment process. ${ }^{248}$ For now, Trump has combined his appointment and directive powers to successfully put his deregulatory aims in motion.

However, Trump has not been entirely successful in his attempts to depower environmental regulation. The Trump Administration attempted to slash the EPA budget, reducing it to levels not seen in a quarter century. The Administration's proposed cuts to the EPA were so severe that they would have disabled the agency far into the future. ${ }^{249}$ However, through one budget cycle,

\footnotetext{
241. Id. $\$ 4$.

242. Review of the Clean Power Plan, 82 Fed. Reg. 16,329 (Apr. 4, 2017).

243. Order, State of West Virginia v. EPA, (D.C. Cir. Apr. 28, 2017) (No. 15-01363), http://www.edf.org/sites/default/files/content/2017.04.28_order_granting_abeyance_cpp.pdf [http:// perma.cc/4TKH-S9C2].

244. Juliet Eilperin \& Brady Dennis, Court Freezes Clean Power Plan Lawsuit, Signaling Likely End to Obama's Signature Climate Policy, WASH. POST (Apr. 28, 2017), $\mathrm{http}: / / \mathrm{www}$.washingtonpost.com/news/energy-environment/wp/2017/04/28/court-freezes-clean-powerplan-lawsuit-signaling-likely-end-to-obamas-signature-climate-policy [http://perma.cc/276W-M6SM].

245. Repeal of Carbon Pollution Emission Guidelines for Existing Stationary Sources: Electric Utility Generating Units, 82 Fed. Reg. 48,035 (Oct. 16, 2017).

246. E.g., Brianne Gorod, If Trump Wants To Abandon the Clean Power Plan, the Courts Shouldn't Give Him Cover, YALE J. ON REG.: NOTICE \& COMMENT (May 8, 2017), http:// yalejreg.com/nc/if-trump-wants-to-abandon-the-clean-power-plan-the-courts-shouldnt-give-him-coverby-brianne-gorod [http://perma.cc/AUS4-BM5H].

247. See Nicholas R. Parrillo, The Fate of the Clean Power Plan Case: Hold in Abeyance, or Remand?, YALE J. ON REG.: NOTICE \& COMMENT (May 5, 2017), http://yalejreg.com/nc/ the-fate-of-the-clean-power-plan-case-hold-in-abeyance-or-remand-by-nicholas-r-parrillo [http://perma. cc/EAV5-56UX].

248. See Clean Air Council v. Pruitt, 862 F.3d 1 (D.C. Cir. 2017); Lisa Friedman, Court Blocks Effort To Suspend Obama-Era Methane Rule, N.Y. TIMES (July 3, 2017), http://www.nytimes.com/2017/07/03/climate/court-blocks-epa-effort-to-suspend-obama-era-methanerule.html [http://perma.cc/UXR7-PWCK]; Lisa Friedman, E.P.A. Reverses Course on Ozone Rule, N.Y. TIMES (Aug. 3, 2017), http:/www.nytimes.com/2017/08/03/climate/epa-reverses-course-on-ozonerule.html [http://perma.cc/9YR6-4AZQ].

249. See Devin Henry, Trump Takes Hatchet to EPA, HILl (Mar. 1, 2017), http:// thehill.com/policy/energy-environment/321684-trump-takes-hatchet-to-epa [http://perma.cc/952J-
} 
the GOP-controlled Congress largely ignored his demand for deep EPA cuts and kept EPA funding close to flat. ${ }^{250}$ That congressional rebuke of Trump's EPA budget was part of a broader pattern of general bipartisan disregard for major aspects of what Professor Strauss terms Trump's "deconstructive" spending plan..$^{251}$

On the international side, Trump was not quite as aggressive in immediately unwinding Obama's signature accomplishment. In June 2017, Trump ultimately decided to withdraw from the Paris Agreement. ${ }^{252}$ As Professor Goldsmith notes, the Paris Agreement was "fragil[e]," since "[p]olitical commitments that skirt Congress can be reversed by a subsequent president." 253 Indeed, Trump could have given notice of withdrawal the moment he was sworn in. Instead, his Administration was seemingly divided over whether to leave the Agreement. ${ }^{254}$ As Professor Koh notes, under the Agreement's terms, Trump "could not formally withdraw the United States from its Paris obligations until the start of the next four-year presidential term."255 That required timeframe, from an agreement that is mostly non-binding, made withdrawal less attractive. If Trump's domestic deregulatory efforts on climate change are successful, the domestic and international political ramifications of withdrawal might not be worth it. Indeed, Trump seemingly faced more immediate political blowback for withdrawing from Paris, both at home and abroad, than he did for starting to unwind the domestic policies that operationalized the agreement. ${ }^{256}$

N4NZ] (quoting Democratic Rep. Raúl Grijalva saying, "If this budget is enacted the way he [Trump] wants it, he's effectively dealt a very significant death blow to the EPA.").

250. How Science Fares in the U.S. Budget Deal, SCI. MAG. (May 1, 2017, 11:15 AM), $\mathrm{http}: / / \mathrm{www}$.sciencemag.org/news/2017/05/how-science-fares-us-budget-deal [http://perma.cc/99BJA9DQ].

251. Strauss, supra note 129, at 13; see Carl Hulse, Why Congress's Bipartisan Budget Deal Should Make Trump Worried, N.Y. TIMES (May 1, 2017), http://www.nytimes.com/2017/05/01/us/ politics/congress-budget-deal-democrats-republicans.html [http://perma.cc/KC55-GDMH]; Robert Pear, Congress Rejects Trump Proposals To Cut Health Research Funds, N.Y. TIMES (Sept. 11, 2017), http://www.nytimes.com/2017/09/11/us/politics/national-institutes-of-health-budget-trump.html [http://perma.cc/N4TS-TZEF].

252. Camila Domonoske \& Colin Dwyer, Trump Announces U.S. Withdrawal From Paris Climate Accord, NPR (June 1, 2017), http://www.npr.org/sections/thetwo-way/2017/06/01/ 530748899/watch-live-trump-announces-decision-on-paris-climate-agreement [http://perma.cc/2NMA9YHQ].

253. Goldsmith, supra note 229 , at 471.

254. Evan Halper, Republicans Are Rethinking Their Disdain for the Paris AccordCreating a Political Headache for Trump, L.A. TIMES (Apr. 27, 2017), http://www.latimes.com/ politics/la-na-pol-trump-paris-20170427-story.html [http://perma.cc/D5J6-TSN9]; Chris Mooney \& Brady Dennis, Scott Pruitt Calls for an 'Exit' from the Paris accord, Sharpening the Trump White House 's Climate Rift, WASH. POST (Apr. 14, 2017), http://www.washingtonpost.com/news/energy-environment/ wp/2017/04/14/trumps-epa-chief-scott-pruitt-calls-for-an-exit-to-the-paris-climate-agreement [http:// perma.cc/M2GZ-B738]. The Administration's ultimate decision seems to rest on how it interprets its ability to lower U.S. carbon reduction commitments under the Agreement. John Schwartz, Debate over Paris Climate Deal Could Turn on a Single Phrase, N.Y. TIMES (May 2, 2017), http://www.nytimes.com/ 2017/05/02/climate/trump-paris-climate-accord.html [http://perma.cc/RSH5-JYV3].

255. Koh, supra note 227 , at 357.

256. See, e.g., Scot Clement \& Brady Dennis, Post-ABC Poll: Nearly 6 in 10 Oppose Trump Scrapping Paris Agreement, WASH. POST (June 5, 2017) (showing broad disagreement with 


\section{Climate Policy Prospects}

Our look at climate policy highlights both the power and perils of presidentialism. Bold action is possible, but it may not be durable. And Congress still holds the purse strings. First, durability: the Obama CPP was a bold move internationally and domestically, but it was also particularly fragile in the face of presidentialist reversal. The major Obama climate actions are on their way to elimination. Post-CPP repeal litigation will largely determine the extent to which pro-regulatory litigants can use courts to at least delay Trump's deregulatory efforts. Whether EPA can produce a reasoned case for rescission of its regulation remains to be seen. But even if the regulation were to remain in place, enforcement is unlikely. Attempts to force regulatory or enforcement action through litigation are almost certain losers. ${ }^{257}$ On the other hand, history may be on the side of the CPP. Emissions reduction could continue into the future because of market and technological trends that began during and arguably, in part, due to the Obama Administration, even as Trump rolls back climate regulation. ${ }^{258}$

The rescission of domestic climate policy contrasts sharply with the temporary stickiness of the Paris Agreement. Even though the Trump Administration ultimately announced its intention to withdraw, it proved politically more difficult to abrogate the Paris Agreement than to stymie Obama's domestic initiatives. The Paris Agreement, like DACA in the immigration context, is harder to undo because of the political costs. But, as with DACA, initial durability was more a function of politics than formal legal constraints on presidential administration. Withdrawal from the Paris Agreement demands no administrative process and is not subject to judicial review.

The Paris Agreement thus illustrates the high policy risk, in general, of presidential administration as applied to international law. Because Obama operationalized the United States' compliance with the Paris Agreement through domestic regulatory authority that is formally unrelated to the Agreement, the litigation over the CPP threatened to cause a breach of U.S. commitments under the Agreement. When the President stretches domestic power to unilaterally

decision to withdraw from the Paris Agreement), http://www.washingtonpost.com/news/energyenvironment/wp/2017/06/05/post-abc-poll-nearly-6-in-10-oppose-trump-scrapping-paris-agreement [http://perma.cc/R66U-XGFR]. While it is hard to compare public sentiment on these two points empirically, our sense is that the Paris Agreement withdrawal was the more acutely negative event, in terms of public reaction.

257. Indeed, we have seen Administrator Pruitt pull back EPA enforcement in other areas. E.g., Pruitt Moves To Curb E.P.A. 's Power To Demand Pollution Tests, N.Y. TiMEs (Dec. 9, 2017), http:/www.nytimes.com/interactive/2017/12/09/us/politics/document-EPA-Clean-Air-Act-and-ItsPower-to-Request.html [http://perma.cc/72CQ-M8MF].

258. See, e.g., CHAIT, supra note 200 , at 140 ("In some ways, the work of the green energy revolution has already changed the economic calculus irreversibly. By the end of 2016, American power plants had already met their 2024 emissions reduction targets . . " "); Koh, supra note 227 , at 361 ("The shift in investment patterns toward renewable energy may have reached a point where it is very hard to reverse."). 
make international agreements, he "has no guarantee that domestic law will permit the United States to fulfill the pledges made in the [international] political commitments."259 Professor Goldsmith views such judicial and legislative constraints on domestic regulatory efforts to fulfill international agreements as an accountability mechanism on the President, but that accountability also makes these agreements operationally precarious. ${ }^{260}$

Second, Trump's initial experience with EPA appropriations challenges the Levinson-Pildes "separation of parties" thesis. The unified GOP Congress mostly maintained EPA funding even as the Trump Administration wanted to dramatically curtail it. One imagines that certain Republican congressmeneven if they were aligned with many aspects of the Trump climate agenda-had EPA offices or projects in their home states and districts that would not have survived the cuts. At least some separation of powers checks are maintained in this unified government.

But climate policy also teaches a contrary lesson. Here again is a major policy area where Congress has essentially ceded all meaningful policymaking to the executive branch. The executive has become more and more capable of action as the legislature has become less and less so. That, only eight or nine years ago Congress seemed poised to pass major climate legislation is rather remarkable, given how unlikely any such action would be now. As with immigration, presidential administration has grown with gridlock. From that perspective, the separation of powers motivates presidentialism rather than constraining it.

\section{The Construction (and Deconstruction) of the Administrative State}

Aside from certain landmark legislation during the first two years of his presidency when Democrats controlled Congress, ${ }^{261}$ Obama's primary achievements were regulatory. Aside from the Tax Cuts and Jobs Act, ${ }^{262}$ the early Trump presidency's domestic achievements have been, likewise, almost entirely deregulatory. Central to both administrations' success was how they ordered and re-ordered the administrative state in furtherance of their actions.

\section{Obama's Construction}

This Part focuses attention on three aspects of Obama's ordering of the administrative state: (i) his modest restructuring of the OIRA review process for

259. Goldsmith, supra note 229, at 465-66; see id. at 471 ("In other words, the core of the President's pledge in Paris is subject to judicial review pursuant to the Administrative Procedure Act.").

260. Id. at 471 .

261. See Patient Protection and Affordable Care Act, Pub. L. No. 111-148, 124 Stat. 119 (2010); Dodd-Frank Wall Street Reform and Consumer Protection Act, Pub. L. No. 111-203, 124 Stat. $1376(2010)$ (codified at 12 U.S.C. $\$ 1851(2018)$ ).

262. Pub. L. No. 115-97, 131 Stat. 2054 (2017). 
rulemaking, along with other policy changes he made to influence the costbenefit balancing at the analytical heart of the OIRA process, (ii) his use of White House policy "czars" to coordinate administrative action, and (iii) his Administration's aggressive, adjudication-oriented enforcement initiatives to promote consumer protection and corporate responsibility.

In Kagan's presidentialist narrative, a key feature of presidential administration for both Reagan and Clinton was how each, through Executive Orders, constructed regulatory review at OIRA. ${ }^{263}$ This institutionalization of presidentialism has proved relatively durable. For Obama, notwithstanding the bold rulemakings that defined his presidency, his formal changes to the OIRA process were fairly minor. At the beginning of his presidency, his initial OIRA Executive Order merely rolled back two of Bush II's EOs that altered the OIRA process from what Clinton had created. ${ }^{264}$ But those Bush II EOs had themselves made fairly minor changes to the Clinton process. ${ }^{265}$ Thus, Obama merely reestablished the Clinton process, which had remained much the same through Bush II's tenure.

Later in his first term, Obama signed another Executive Order on regulatory process, but this second EO, by its own terms, was "supplemental to and reaffirm[ed] the principles ... that were established in [Clinton's] Executive Order 12866." 266 Although Obama's second foray into regulatory review was notable for its recognition of the importance of considering non-monetizable values in agency regulatory analyses, ${ }^{267}$ this second EO brought nothing like the process sea changes of Reagan and Clinton. ${ }^{268}$ This administrative conservativism perhaps embodied an early streak of regulatory skepticism in

263. See supra Part II.

264. Exec. Order No. 13,497, 74 Fed. Reg. 6,113 (Feb. 4, 2009). Moreover, OMB effectively retained certain Bush II changes that EO 13,497 had seemingly revoked. See Memorandum from Peter R. Orzag, Dir., Off. of Mgmt. \& Budget, to the Heads and Acting Heads of Exec. Dep'ts and Agencies (Mar. 4, 2009), http://obamawhitehouse.archives.gov/sites/default/files/omb/assets/memoranda _fy2009/m09-13.pdf [http://perma.cc/JL98-JR55].

265. See Exec. Order No. 13,258, 67 Fed. Reg. 9,385 (Feb. 2, 2002), http:// www.gpo.gov/fdsys/pkg/FR-2002-02-28/pdf/02-5069.pdf [http://perma.cc/J85W-N7ZL] (making fairly minor changes to certain lines of authority in review process); Exec. Order No. 13,422, 72 Fed. Reg. 2,763 (Jan. 23, 2007); see also Roger G. Noll, The Economic Significance of Executive Order 13,422, 25 YALE J. ON REG. 113, 123 (2008) ("Executive Order 13,422 is not very important in the grand scheme of regulatory policy.").

266. Exec. Order No. 13,563, 76 Fed. Reg. 3,821, 3,821 §1(b) (Jan. 21, 2011). Another Obama Executive Order recommended (but did not require) that independent agencies comply with Executive Order 13,563. Exec. Order No. 13,579, 76 Fed. Reg. 41,587 (July. 14, 2011).

267. See Rachel Bayefsky, Note, Dignity as a Value in Agency Cost-Benefit Analysis, 123 YALE L.J. 1732, 1736 (2014) (discussing the Executive Order's explicit inclusion of non-monetizable dignity as a factor that agencies can consider in cost-benefit analyses).

268. But see Cass R. Sunstein, The Office of Information and Regulatory Affairs: Myths and Realities, 126 HARV. L. REV. 1838, 1846 (2013) (calling Executive Order 13,563 "a document of signal importance in the Obama Administration, indeed a kind of mini-constitution for the regulatory state"). 
President Obama ${ }^{269}$-a skepticism that seemingly gave way as regulatory initiatives came to define the latter three-quarters of his presidency. Or perhaps the durability of the OIRA review process is better understood as another example of Shane's "one-way ratchet." Whatever the precise criteria for acceptable regulatory impact analyses, that they are required institutionalizes EOP control over major administrative policy making.

The Obama years thus cemented the core, OIRA-supervised, rulemaking process as the "new normal" in American administrative governance, ${ }^{270}$ to the chagrin of some on the left. ${ }^{271}$ The Obama Administration's trans-substantive, pro-regulatory changes to the rulemaking environment came elsewhere. The Obama initiatives shifted the cost-benefit calculus within the EO 12,866 framework, rather than altering the framework itself. A crucial move was the formation of an inter-agency working group to estimate the social cost of carbon emissions-a cost that the working group subsequently revised upward. ${ }^{272}$ This carbon cost estimate (as well as quantified costs for other greenhouse gases) shifted cost-benefit calculations across multiple agency rulemaking processes. ${ }^{273}$ The higher the quantified cost of carbon pollution, the more regulation to combat carbon emissions became justified. The Obama Administration also insinuated climate-conscious reasoning into administrative processes in numerous other ways. ${ }^{274}$ Similarly, various agencies increased, often dramatically, the value

269. Binyamin Applebaum \& Michael D. Shear, The Obama Era, Part 1: The Regulator in Chief, N.Y. TIMES (Aug 13, 2016), http://www.nytimes.com/2016/08/14/us/politics/obamaera-legacy-regulation.html [http://perma.cc/SV33-CNJA] (arguing that Obama "entered office ... determined to make his mark by passing bold new laws, not by tinkering with rules" and that "[t]he new president had a skeptical streak when it came to the value of regulation, influenced by ... Cass $R$. Sunstein, a Harvard Law professor who had long argued that the government should more rigorously assess the benefits of new regulations. Mr. Obama liked that idea so much that he named Mr. Sunstein to lead" OIRA).

270. See, e.g., Eric A. Posner, Obama's Cost-Benefit Revolution, NEW REPUBLIC (Jan. 22, 2011), http://newrepublic.com/article/81990/obama-cost-benefit-revolution [http://perma.cc/M6HZW8YC] (finding, contrary to the article's title, non-revolutionary continuity between Obama's approach and those of Reagan and Clinton).

271. See, e.g., Douglas A. Kysar, Politics by Other Meanings: A Comment on "Retaking Rationality Two Years Later," 48 Hous. L. REV. 43 (2011); Susan Rose-Ackerman, Putting Cost-Benefit Analysis in Its Place: Rethinking Regulatory Review, 65 U. MIAMI L. REV. 335 (2011); Richard Lacayo, Why Obama 's Regulatory Czar Makes Liberals Nervous, TIME (Feb. 24, 2009), http://content time.com/time/politics/ article/0,8599,1881473,00.html [http://perma.cc/A7LH-WDS6].

272. INTERAGENCY WORKING GRP. ON SOC. COST OF CARBON, TECHNICAL UPDATE OF THE SOCIAL COST OF CARBON FOR REGULATORY IMPACT ANALYSIS UNDER EXECUTIVE ORDER 12866 (May 2013, Rev. July 2015), http://obamawhitehouse.archives.gov/sites/default/files/omb/inforeg/scctsd-final-july-2015.pdf [http://perma.cc/8UX9-2ECL].

273. See JANE A. LegGetT, CONG. Res. Serv., R44657, Federal Citations to the SOCIAL COST OF GREENHOUSE GASES (Mar, 21, 2017), http://www.hsdl.org/?view\&did=799816 [http://perma.cc/M55V-7T3G]; Applebaum \& Shear, supra note 269 ("Quantifying . . damage ... from carbon emissions, would broaden the assessed benefits of new regulations-potentially justifying new and stronger restrictions.").

274. See Hoshijima, supra note 201. 
assigned to a saved life for cost-benefit purposes. ${ }^{275}$ This higher quantified benefit was, again, pro-regulatory. ${ }^{276}$

Elsewhere, the Bush II Administration had engaged in information practices concerning scientific matters, particularly as related to climate change that can be described as information suppression. ${ }^{277}$ The Obama Administration reversed course. It made a strong push for transparency and political nonintervention in public study and dissemination of conclusions about science and technology. ${ }^{278}$ While not inherently pro-regulatory, information transparency tended to counter the Bush II political interventions in government science that were anti-regulatory. Scientific integrity and transparency is undoubtedly a positive development in itself, but it also worked to further Obama's regulatory agenda of shifting the balance of costs and benefits in a pro-regulatory direction. ${ }^{279}$

275. Binyamin Applebaum, As U.S. Agencies Put More Value on a Life, Businesses Fret, N.Y. TIMES (Feb. 16, 2011), http://www.nytimes.com/2011/02/17/business/economy/ 17regulation.html [http://perma.cc/9YAD-33XW].

276. Not all Obama-era calculative cost-benefit changes were pro-regulatory. Congress passed legislation that provided the FDA with certain regulatory authority over tobacco. Family Smoking Prevention and Tobacco Control Act, Pub. L. No. 111-31, Div. A, 123 Stat. 1776 (2009) (codified at 21 U.S.C. $\S \S 387-87 t$ ). But in 2014 , a cost-benefit analysis that the FDA's economists prepared cast doubt on the agency's major rulemaking efforts pursuant to that new authority. Preliminary Regulatory Impact Analysis, Deeming Tobacco Products To Be Subject to the Food, Drug, and Cosmetic Act, FOOD \& DRUG ADMIN. (Apr. 2014), http://www.regulations.gov/document?D=FDA-2014-N-0189-20877 [http:// perma.cc/G55Z-KVJ7]; Micah Berman, Cost-Benefit Analysis, the FDA, and Tobacco, YALE J. ON REG.: NOTICE \& COMMENT (Sept. 16, 2014), http://yalejreg.com/nc/cost-benefit-analysis-the-fda-and-tobaccoby-micah-berman [http://perma.cc/87BM-MK2P]. Because the FDA economists insisted that the agency consider the loss of enjoyment from smoking that its rule would impose on smokers as a part of the costs of the rule, the welfare gain was relatively modest when those costs were compared with the rule's anticipated health benefits. Sharon Begley, FDA Calculates Costs of Lost Enjoyment If E-Cigarette Rules Prevent Smoking, REUTERS (June 2, 2014); Sabrina Tavernise, In New Calculus on Smoking, It's Health Gained vs. Pleasure Lost, N.Y. TIMES (Aug. 6, 2014), http://www.nytimes.com/2014/08/07/health /pleasure-factor-may-override-new-tobacco-rules.html [http://perma.cc/TM8B-QBDL]. According to press reports, this analysis made the rulemaking proposal harder to defend. Celia Wexler, How Much Is the 'Lost Pleasure' from a Cigarette Worth?, LIVESCIENCE (June 24, 2014, 5:15 PM), http:// www.livescience.com/46503-value-of-lost-pleasure-from-smoking.html [http://perma.cc/C2PR-QGHF].

277. SHANE, supra note 48 , at 167 .

278. Scientific Integrity: Memorandum for the Heads of Exec. Dep'ts and Agencies, 74 Fed. Reg. 10,671, 10,671 (Mar. 9, 2009) ("Political officials should not suppress or alter scientific or technological findings and conclusions. If scientific and technological information is developed and used by the Federal Government, it should ordinarily be made available to the public. To the extent permitted by law, there should be transparency in the preparation, identification, and use of scientific and technological information in policymaking. The selection of scientists and technology professionals for positions in the executive branch should be based on their scientific and technological knowledge, credentials, experience, and integrity."); Memorandum from John P. Holdren, Assistant to the President for Sci. \& Tech., Sci. Integrity, to Heads of Executive Departments and Agencies (Dec. 17, 2010), http:// obamawhitehouse.archives.gov/sites/default/files/microsites/ostp/scientific-integrity-memo12172010.pdf [http://perma.cc/FZU8-MPKB] (elaborating on the presidential directive).

279. The Obama Administration still faced accusations of meddling in science when it suited political goals. One controversy concerned the prescription status of "Plan B" contraception pills. See Tummino v. Hamburg, 936 F. Supp. 2d 162, 170-71 (E.D.N.Y. 2013) ("Thus, three distinguished scientists, including the Editor-in-Chief of the New England Journal of Medicine, wrote: 'In our opinion, the [HHS] Secretary's decision to retain behind-the-counter status for Plan B One-Step was based on politics rather than science." (quoting The Politics of Emergency Contraception, 366 NEW ENG. J. MED. 
Moving from process to personnel, a noted feature of the Obama Administration was its heavy reliance on so-called "czars," 280 presidential advisors, generally (functionally if not formally) located within the EOP who often exercised immense authority (if de facto rather than de jure) over presidential administration in a given policy domain. Policy czars (and similar centralizing mechanisms) are not new. President Clinton created the National Economic Council, and the Office of Science and Technology Policy and Council on Environmental Quality have existed since the 1970s as mechanisms to centralize policymaking in the White House.

However, Obama used policy czars "far more pervasively than any previous administration." 281 In assessing the tools for presidential supervision, these policy czars are sometimes treated as equivalent to OIRA review in operationalizing presidential directive authority through a restructured administrative state. ${ }^{282}$ And these "czars," although presumably in charge of major policy areas, are not department heads requiring Senate confirmation of their appointments.

To take one example from the beginning of Obama's tenure, when Obama needed a point-person to address the floundering U.S. auto industry, he did not rely on the Department of Transportation or its Secretary. Instead, he appointed financier Steven Rattner as his "car czar." As the U.S. auto industry teetered on the brink of collapse in early 2009, Rattner managed the U.S. government's investment of nearly eighty billion dollars (USD) into the automotive sector, chiefly through investments in GM and Chrysler. ${ }^{283}$.

101, 102 (2012))); Lisa Heinzerling, The FDA's Plan B Fiasco: Lessons for Administrative Law, 102 GEO. L.J. 927 (2014); see also Kathryn A. Watts, Controlling Presidential Control, 114 MICH. L. REV. 683, 706-16 (2016) (describing how Plan B saga demonstrated "interfering with science"); Heidi Kitrosser, Scientific Integrity: The Perils and Promise of White House Administration, 79 FORDHAM L. REV. 2395 (2011) (discussing "the Obama Administration's relationship to scientific information").

280. For an informal listing of Obama's czars through the first six years of his Administration, see Arit John, The Encyclopedia of All 34 of Obama's Czars, From A to Zients, BLOOMBERG (Oct. 25, 2014), http://www.bloomberg.com/politics/articles/2014-10-25/the-encyclopediaof-all-34-of-obamas-czars-from-a-to-zients [http://perma.cc/BQR4-EQW7].

281. Aaron J. Saiger, Obama's "Czars" for Domestic Policy and the Law of the White House Staff, 79 FORDHAM L. REV. 2577, 2578 (2011); see also Watts, supra note 279, at 704 ("Although czars have 'solid roots in earlier administrations,' Obama has used regulatory czars more heavily than other Presidents." (internal citations omitted)); Kevin Sholette, Note, The American Czars, 20 CORNELL J.L. \& PUB. POL'Y 219 (2010).

1857. (2015).

282. Gillian E. Metzger, The Constitutional Duty to Supervise, 124 YALE L.J. 1836,

283. For an enlightening economic account of the auto bailout, see Austan D. Goolsbee \& Alan B. Krueger, A Retrospective Look at Rescuing and Restructuring General Motors and Chrysler 28 (Nat'l Bureau of Econ. Research, Working Paper No. 21000, 2015), http://www.nber.org/ papers/w21000 [http://perma.cc/4J5L-VP5P]. For a skeptical perspective on Rattner's work as car czar, see Malcolm Gladwell, Overdrive: Who Really Rescued General Motors?, NEW YORKER (Nov. 1, 2010), http://www.newyorker.com/magazine/2010/1 1/01/overdrive-2 [http://perma.cc/N8VU-RFXE]. 
On Rattner's telling, the decision to bail out Chrysler, at least to a certain degree, essentially was his to make. ${ }^{284}$ Congress "had already appropriated funds for the auto bailout during the end of the Bush administration," but Rattner's team decided how the bailout money would be spent. ${ }^{285}$ Among other myriad, sector-defining decisions, Rattner led negotiations with lenders over multibillion debt restructurings for Chrysler and GM, and he personally, "on behalf of" the President, "demanded that GM's chief executive at the time ... step down."286 According to Rattner, his broad authority-his nearly unilateral executive power-was necessary. He argues if congressional approval had been necessary for these decisions, "at least one" of the major U.S. automakers would have "collapsed." 287

To take another example from the later Obama years, the President appointed Ron Klain as his "Ebola czar" in 2014. The Klain appointmentwhich was, for the most part, forgotten soon after it happened, as U.S. fears over the disease abated ${ }^{288}$ _is mainly interesting for the political purpose it served. Obama appointed a "czar" to show decisive presidential leadership, as a means to quell American panic over the disease's potential spread into the US. The appointment came as Congress pummeled agency leaders for missteps in the domestic response. ${ }^{289}$ The czar appointment thus was a way to respond to congressional criticism and mollify an anxious country. Indeed, in the modern presidency, "presidential appointment of czars during the aftermath of a crisis has become increasingly commonplace." 290 Obama was presumed to be directly responsible for (and in control of) the government's response, and the Ebola czar was his reaction to that political expectation. Once again, we observe Shane's one-way ratchet. The more presidents take control, the more the public expects them to exercise it-whatever the formal statutory allocation of authority.

284. Inside Obama's Auto Industry 'Overhaul', NPR: ALL THINGS CONSIDERED (Sept. 20, 2010), http://www.npr.org/2010/09/20/129993024/inside-obama-s-auto-industry-overhaul [http:// perma.cc/5UYH-LGL5] [hereinafter Obama Overhaul].

285. Id.

286. Neil King, Jr., Auto Czar Quits Post Six Months into the Job, Wall ST. J. (July 14, 2009), http://www.wsj.com/articles/SB124751573500734529 [http://perma.cc/84QE-VVCD].

287. Obama Overhaul, supra note 284.

288. Russell Berman, A Quiet Exit for a Forgotten Ebola Czar, ATLANTIC (Dec. 8, 2014), http:/www.theatlantic.com/politics/archive/2014/12/ebola-czar-ron-klain-to-depart/383554/ [http://perma.cc/5UUF-7F2Y]; Marin Cogan, The Brief-But Busy-Reign of the Ebola Czar, N.Y. MAG.: DAILY INTELLIGENCER (Feb. 1, 2015), http://nymag.com/daily/intelligencer/2015/01/ron-klain-on-histenure-as-americas-ebola-czar.html [http://perma.cc/4WM8-YLGS] ("You may have temporarily forgotten Klain.").

289. Juliet Eilperin \& David Nakamura, Obama Taps Ron Klain as Ebola Czar, WASH. POST (Oct. 17, 2014), http://www.washingtonpost.com/news/post-politics/wp/2014/10/17/obama-tapsron-klain-as-ebola-czar [http://perma.cc/MQX5-7GJS]; Jack Healy et al., Obama May Name 'Czar' To Oversee Ebola Response, N.Y. TIMES (Oct. 16, 2014), http://www.nytimes.com/2014/10/17/us/obamamay-name-ebola-czar-after-amber-joy-vinson-flight-causes-concern.html [http://perma.cc/3DJD-T78K].

290. Anna Spain Bradley, Cognitive Competence in Executive-Branch Decision Making, 49 CONN. L. REV. 713, 728 (2017). 
This "proliferation of high-profile czars" obviously is another means for expanding presidentialism. ${ }^{291}$ When policy authority is pulled from agencies into the EOP, the President does not even need to bother with directives, since the policy chief is his own employee. Acting outside traditional agency structures, a czar can also serve a coordinating function across the bureaucracy, which is perhaps the best practical justification for the role. ${ }^{292}$ As Professor Aaron Saiger puts it, a czar provides "an attractive synthesis of the technocratic advantages traditionally associated with the agency form and the political responsiveness ordinarily attributed to the White House staff."293 But the czar role can also inhibit accountability mechanisms that would exist at the agency level, like congressional oversight and public information access. ${ }^{294}$ For that reason (admittedly as refracted through partisanship), Obama's czars precipitated a minor separation-of-powers flare-up, when Congress attempted to use its budgetary power to defund certain czar positions in the EOP. Although the positions were already defunct, President Obama felt it necessary to push back in a signing statement that argued the failure to fund these positions interfered with the President's constitutional responsibility to assure faithful execution of the laws (and therefore violated the separation of powers). ${ }^{295}$

A third theme concerning structural approaches to the administrative state was the Obama Administration's relatively aggressive adjudicatory enforcement initiatives to promote consumer protection and corporate responsibility. ${ }^{296}$ Although these adjudicatory efforts involved the creation of no new offices or significant changes in process, we treat them as "structural" for two reasons. First, much of the literature on presidential administration and presidential power emphasizes presidential policymaking through legislative rules or Executive Orders having a similar effect. The use of enforcement discretion as a regulatory or deregulatory device has not had similar attention, although it is surely equally

291. Saiger, supra note 281 , at 2583 ("President Obama's proliferation of high-profile czars is his particular instantiation of a policy, common to all modern Presidents, of seeking to magnify his control over agency action in domestic policy."); see also Gillian E. Metzger, Agencies, Polarization, and the States, 115 COLUM. L. REV, 1739, 1751-52 (2015) ("White House 'czars' have emerged as a means by which the White House can coordinate and control policy in areas of key concern to the President.").

292. See Watts, supra note 279 , at 704-05.

293. Saiger, supra note 281 , at 2583.

294. Id. at 2594 ("[C]zars are free of the burden of justifying their own actions to congressional committees. Their budgets come through the Executive Office of the President; they need not justify themselves to the Senate at confirmation; they partake of executive privilege, to the extent that it is available; and they are generally immune, as discussed below, to administrative discovery through the Freedom of Information Act.").

295. Saiger, supra note 281 , at $2578-79,2603-04$. As Saiger points out, this was a breathtakingly broad claim-tantamount to saying Congress was required to fund the EOP at whatever level the President requested.

296. In the broader scheme of federal law enforcement, one could also consider the Obama Administration's attempts to curb the reach of federal drug laws, through the use of sentencing discretion, commutations, and effective non-intervention in state drug legalization efforts (even when that state-level legalization conflicted with federal law). 
important. The DACA and DAPA policies previously discussed concern enforcement actions that would be carried out through individual adjudications. The same is true of Trump's counter-moves to ramp up deportation. While rulemaking is a more high-visibility approach to presidential policy direction, the management of enforcement priorities may be a more powerful tool for presidential administration.

With relative ease given the general non-reviewability of prosecutorial discretion, the Obama Administration pushed the more muscular use of adjudication and regulatory enforcement actions across agencies to further policy goals of consumer and environmental protection, financial regulation, and corporate responsibility - what we will call, for economy of phrasing more than anything else, "white-collar enforcement." A common left-wing complaint against the Obama Administration was its softness on white-collar crime, particularly in terms of criminal prosecutions against large financial institutions. ${ }^{297}$ This Article takes no position on whether that critique is or is not valid in an absolute sense, but at least relative to prior practice, white-collar enforcement was notably more muscular under Obama.

The Obama years brought a parade of multi-billion dollar settlements related to corporate and financial crime. Corporate settlements of this size certainly existed before Obama, but the number and prosecutorial intensity of these cases were much greater. ${ }^{298}$ Record-size settlements for various legal violations felt like the new normal. To recount some highlights, Volkswagen paid nearly fifteen billion dollars (USD) to settle charges related its emissions scandal (with regulators still apparently considering criminal charges against individual executives); ${ }^{299}$ BP paid over twenty-three billion in civil and criminal penalties (along with guilty pleas to criminal charges) for the Gulf oil spill; ${ }^{300}$ five large U.S. banks paid twenty-five billion dollars for shoddy foreclosure

297. E.g., Rigged Justice: How Weak Enforcement Lets Corporate Offenders Off Easy, OFF. SEN. ELIZABETH WARREN (2016), http://www.warren.senate.gov/files/documents/Rigged_Justice 2016.pdf [http://perma.cc/W8MM-XCS2]. This criticism came to a head when then-Attorney General $\bar{E}$ ric Holder remarked in congressional testimony that certain financial firms are too large and systemically important to criminally prosecute. See Danielle Douglas, Holder Concerned Megabanks Too Big To Jail, WASH. POST (Mar. 6, 2013), http:/www.washingtonpost.com/business/economy/holder-concernedmegabanks-too-big-to-jail/2013/03/06/6fa2b07a-869e-1 le2-999e-5f8e0410cb9d_story.html [http://perma.cc/F3PF-BTY6].

fig. 1 (2016).

298. See Brandon L. Garrett, The Rise of Bank Prosecutions, 126 YALE L.J. F. 33, 36

299. Cary Coglianese \& Jennifer Nash, The Law of the Test: Performance-Based Regulation and Diesel Emissions Control, 34 YALE J. ON REG. 33, 35 (2017) (describing the settlement and other potential corporate and individual legal liability).

300. Tom Fowler, BP Slapped with Record Fine, WALL ST. J. (Nov. 15, 2012), http:/www.wsj.com/news/articles/SB10001424127887324556304578120140555122104 [http:// perma.cc/UR34-EM69]; Daniel Gilbert \& Sarah Kent, BP Agrees To Pay \$18.7 Billion to Settle Deepwater Horizon Oil Spill Claims, WALL ST. J. (July 2, 2013), http://www.wsj.com/articles/bp-agreesto-pay-18-7-billion-to-settle-deepwater-horizon-oil-spill-claims-1435842739][http://perma.cc/8PEQW4CV]. 
practices; ${ }^{301}$ JP Morgan separately settled charges related to mortgage-backed securities for thirteen billion; ${ }^{302}$ and HSBC paid nearly two billion for money laundering violations. ${ }^{303}$ The list could go on. Not included in the above examples are Obama-era prosecutions under America's chief federal anti-bribery law, the Foreign Corrupt Practices Act ("FCPA"), which Obama-era prosecutors commonly used as a tool in white-collar enforcement. While FCPA enforcement was increasing prior to the Obama Administration, the Obama years saw sustained enforcement efforts under the FCPA. ${ }^{304}$

Notwithstanding those massive settlements, the Obama Administration was dogged by claims about its allegedly kid-gloves approach to white-collar enforcement. Seemingly in response to this complaint, the Obama-era DOJ also oriented itself more toward individual criminal charges in white-collar cases. ${ }^{305}$ In what has come to be known as the "Yates Memo"- - a guidance document from the same Deputy Attorney General who Trump subsequently fired when she declined to defend his travel ban as Acting Attorney General-the Justice Department implemented policy changes to enforcement discretion and internal prosecutorial processes to promote individual criminal charges in white-collar cases. ${ }^{306}$ Like DACA and DAPA, the Yates Memo is an immediately reversible ordering of enforcement discretion.

On a more consumer-oriented level, the Obama Administration leveraged the Consumer Financial Protection Bureau (CFPB), which was created through

301. Nick Timiraos et al., U.S., Banks Agree on Foreclosure Pact, WALL ST. J. (Feb. 9 , 2012), http://www.wsj.com/articles/SB10001424052970203315804577211620066795962 [http:// perma.cc/NHS2-3VS2].

302. Devlin Barrett \& Dan Fitzpatrick, J.P. Morgan, U.S. Settle for $\$ 13$ Billion, WALL ST. J. (Nov. 19, 2013), http://www.wsj.com/articles/jp-morgan-us-settle-for-13-billion-1384890222 [http://perma.cc/ER3Z-Q7MK].

303. Devlin Barrett \& Evan Perez, HSBC to Pay Record U.S. Penalty, WALL ST. J. (Dec. 11, 2012), http:/www.wsj.com/articles/SB10001424127887324478304578171650887467568 [http://perma.cc/6JR5-RPPX]. For a partial list that includes other major Obama-era corporate settlements, see David Benoit and Stephen Grocer, Where J.P. Morgan's Settlement Sits in History of Corporate Fines, WALL ST. J. (Oct. 19, 2013), http://blogs.wsj.com/moneybeat/2013/10/19/where-j-pmorgans-settlement-sits-in-history-of-corporate-fines [http://perma.cc/EA6T-YSQ6].

304. Nine of the ten biggest FCPA enforcement actions were settled during the Obama Administration. Richard L. Cassin, Reconsidered: Odebrecht and Braskem Are on our FCPA Top Ten List, FCPA BLOG (Dec. 29, 2016, 8:18 AM), http://www.fcpablog.com/blog/2016/12/29/reconsideredodebrecht-and-braskem-are-on-our-fcpa-top-ten-l.html [http://perma.cc/UF7C-MQXT]. For a critique of this FCPA enforcement, see Michael B. Mukasey \& James C. Dunlop, Can Someone Please Turn on the Lights? Bringing Transparency to the Foreign Corrupt Practices Act, ENGAGE: J. FEDERALIST SOC'Y PRAC. GROUPS, at 30 (2012), http://www.fed-soc.org/library/doclib/20120405 MukaseyDunlopEngage13.1.pdf [http://perma.cc/BS5A-3PH2].

305. Matt Apuzzo \& Ben Protess, Justice Department Sets Sights on Wall Street Executives, N.Y. TIMES (Sept. 9, 2015), http://www.nytimes.com/2015/09/10/us/politics/new-justicedept-rules-aimed-at-prosecuting-corporate-executives.html [http://perma,cc/DX6T-XF72]

306. Memorandum from Sally Q. Yates, Deputy Att'y Gen., on Individual Responsibility for Corp. Wrongdoing. (Sept. 9, 2015), http://www.justice.gov/archives/dag/file/769036 /download [http://perma.cc/BPN6-6V72]; Garrett, supra note 298, at 45. For a good, brief summary of the memo, see Ted Banks \& James Lord, Compliance Programs, Individual Liability, and the Yates Memo: Has Anything Changed?, BUS. L. TODAY, at 1, 1 (June 2016). 
the Dodd-Frank financial reform bill, ${ }^{307}$ with authority over a range of consumer protection issues. In just over five years of operation under the Obama Administration, the CFPB handled one million individual consumer complaints about various financial products. ${ }^{308}$ Through various enforcement actions and investigations, it "has returned approximately $\$ 12$ billion in monetary relief to approximately twenty-seven million consumers over the agency's first five years, including both monetary compensation and principal reductions, cancelled debts, and similar forms of relief," along with another five hundred million dollars in civil penalties. ${ }^{309}$ The CFPB's strong, consumer-level action is central to Obama's white-collar enforcement legacy. But its enforcement posture is unlikely to persist under the Trump Administration. Republicans have consistently derided the CFPB. ${ }^{310}$ That has left the agency intact, but created the distinct possibility, which is seemingly being realized now, that a Trumpappointed agency head would take a decidedly less aggressive regulatory posture.

\section{Trump's Deconstruction}

Early in President Obama's tenure, he delivered a "curt message" to the House Republican majority leader Eric Cantor: "Elections have consequences." 311 One imagines that those words have been echoing in the former president's mind as he watches President Trump seek to eliminate much of his legacy. Indeed, as former presidential advisor Steve Bannon put itadmittedly at a time when his influence with Trump seemed much greater than now-Trump is aiming for the "deconstruction of the administrative state."

307. Dodd-Frank Wall Street Reform and Consumer Protection Act, Pub. L. No. 111203, tit. X, 124 Stat. 1376, 1955-2113 (2010) (codified at 12 U.S.C. $\$ \$ 5491-5603$ (2012)); Kelly Thompson Cochran, The CFPB at Five Years: Beyond the Numbers, 21 N.C. BANKING INST. 55, 55-56 (2017).

308. Cochran, supra note 307 , at 66 .

309. Id. at 59.

310. Jim Puzzanghera, Obama's Consumer Protection Legacy Defined by Aggressive Agency, L.A. TIMES (May 29, 2016), http://www.latimes.com/business/la-fi-obama-consumer-protection20160529-snap-story.html [http://perma.cc/N5GT-TFZG].

311. Julie Hirschfeld Davis, How the Presidency Changed Obama, N.Y. TIMEs (Jan. 17, 2017), http:/www.nytimes.com/interactive/2017/01/17/us/politics/obama-legacy-changed-man.html [http://perma.cc/QG38-YANQ]

312. Philip Rucker, Bannon: Trump Administration Is in Unending Battle for 'Deconstruction of the Administrative State,' WASH. POST (Feb. 23, 2017), http:// www.washingtonpost.com/news/powerpost/wp/2017/02/23/bannon-trump-administration-is-in-

unending-battle-for-deconstruction-of-the-administrative-state [http://perma.cc/3RD9-LFUB]. This stated goal is probably not an apt description of what the Trump Administration has actually done. Most of its actions are designed to roll back exercises of administrative power, but not to reduce the authority of administrative institutions. Indeed, much of the Trump deregulatory agenda depends upon action by administrative agencies that have statutory jurisdictions and authority that the President cannot directly control or exercise. 
In measuring the success of that "deconstruction" to date, ${ }^{313}$ this Article will look at four areas of administrative policy: (i) various deregulatory process requirements that Trump has imposed by executive order, (ii) widespread agency rescission of Obama-era policies not embodied in promulgated rules, (iii) Congress' resolutions under the Congressional Review Act (the CRA) that have rolled back numerous major, late-term Obama-era regulations, and (iv) Trump's use of appointments and his (seemingly now-temporary) installation of administration loyalists at various agencies to monitor political appointees' compliance with administration priorities.

To take each area in turn, let us begin with Trump's executive interventions in regulatory process. As noted above, President Obama did relatively little to alter the Clinton-era cost-benefit framework around which OIRA review is based. President Trump, thus far, has taken the opposite approach; he has attempted to remake the OIRA process. His changes shift the process dramatically into something far more anti-regulatory than the process Reagan created.

Trump's most dramatic changes came in Executive Order $13,771 .^{314}$ In the Order, Trump required that two existing regulations be repealed for every newly promulgated regulation, and that the costs of that new regulation be less than or equal to the cost of those two repealed regulations (together, the " 2 -for- 1 rule") ${ }^{315}$ On a more macro level, the EO authorized the OMB director to impose an annual regulatory cost budget on each federal agency, which OIRA Administrator Rao has begun to do. ${ }^{316}$ Another Order-EO 13,777-instructs agencies to create "Regulatory Reform Task Forces" to identify regulations that should be repealed. ${ }^{317}$ These deregulatory Orders are in addition to more targeted uses of presidential directive authority to roll back Obama-era regulations. ${ }^{318}$

313. For a recent, in-depth discussion of "Anti-Administrativism," see Gillian E. Metzger, 1930s Redux: The Administrative State Under Siege, 131 HARV. L. REV. 1 (2017).

314. Reducing Regulation and Controlling Regulatory Costs, Exec. Order No. 13,771, 82 Fed. Reg. 9,339 (Feb. 3, 2017). We ignore here Trump's formation of agency-level regulatory task forces, which Professor Strauss discusses. Strauss, supra note 129, at 17-18.

315. Exec. Order 13,1771, 82 Fed. Reg. 9,339 at $\$ 2$.

316. Memorandum from Neomi Rao, Admin., Off. of Mgmt. \& Budget (Sept. 7, 2017), http:/www.whitehouse.gov/sites/whitehouse.gov/files/omb/memoranda/2017/FY\%202018\%20Regulato ry\%20Cost \%20Allowances.pdf [http://perma.cc/7WCW-ABMJ].

317. Enforcing the Regulatory Reform Agenda, Exec. Order No. 13,777, 82 Fed. Reg. 12,285 (Feb. 24, 2017).

318. See, e.g., supra Section IV.B.2; Identifying and Reducing Tax Regulatory Burdens, Exec. Order No. 13,789, 82 Fed. Reg. 19,317 (Apr. 26, 2017). For EO 13,789, deregulation in $\operatorname{tax}$ is especially likely to be successful, given the virtual impossibility of attaining standing to challenge a rescission in tax that is taxpayer-friendly. See Andy Grewal, Trump's Broad Powers To Revoke Tax Regulations Issued by the Obama Administration, 36 YALE J. ON REG.: NOTICE \& COMMENT (Nov. 14, 2016), http://yalejreg.com/nc/trumps-broad-powers-to-revoke-tax-regulations-issued-by-the-obamaadministration [http://perma.cc/WW5D-AW6K]. 
The 2-for-1 rule seeks to impose on top of cost-benefit analysis what has been called "cost-cost analysis." 319 In addition, as one commentator described the effects of regulatory budgets, "Maximizing net benefits will have no place in the new EO's regulatory budget model. By default, agencies will have a strong incentive to pick the rule that is least costly to industry stakeholders-even if the net benefits of a slightly more costly rule would be substantially greater-in order to meet budget caps. ${ }^{.320}$ In other words, EO 13,771, if effective (and that is an open legal question), completely changes the regulatory impact analysis paradigm for the administrative state.

The 2 -for- 1 rule and the related regulatory budget may be legally ineffective as a basis for deregulation. In repealing rules as in promulgating them, ${ }^{321}$ the APA requires that agencies give reasons for repeal that are cognizable under the statute that authorized the rule. ${ }^{322}$ Absent such reasons, the rule is considered arbitrary, and the 2-for-1 aspect of the EO seems particularly vulnerable in this context. ${ }^{323}$ For any given authorizing statute, it is unlikely to be a cognizable reason for repealing a rule that the repeal is required under an executive order to make way for another, unrelated rule. ${ }^{324}$ Moreover, where a

319. Amit Narang, The Stunning Triumph of Cost-Cost Analysis, REG. REV. (Feb. 19, 2017), http:/www.theregreview.org/2017/02/19/narang-stunning-triumph-cost-cost-analysis [http://] perma.cc/6G7C-34HQ]. Per OMB guidance on EO 13,711, cost-benefit analysis in accordance with EO 12,866 is still required, in addition to compliance with the Trump regulatory orders. M-17-21, Memorandum from Dominic J. Mancini, Acting Admin., OIRA 2 (Apr. 5, 2017), http:// www.whitehouse.gov/sites/whitehouse.gov/files/omb/memoranda/2017/M-17-21-OMB.pdf [http:// perma.cc/2YP-Q3GD].

$$
\text { 320. Id. }
$$

29 (1983).

321. See Motor Vehicle Mfrs. Ass'n of U.S. v. State Farm Mut. Auto. Ins. Co., 463 U.S.

322. Agencies can only cite types of reasons that they are permitted to consider under the statute or statutes authorizing their action. See, e.g., D.C. Fed'n of Civic Ass'ns v. Volpe, 459 F.2d 1231, 1245-46 (D.C. Cir. 1971).

323. At least one conservative commentator expressed reservation about it. Brian Knight, Quick Reaction to President Trump's Regulation Reduction Executive Order, YALE J. ON REG.: NOTICE \& COMMENT (Jan. 30, 2017), http://yalejreg.com/nc/quick-reaction-to-president-trumpsregulation-reduction-executive-order-by-brian-knight/ [http://perma.ce/S2KZ-FNZB] ("A regulatory budget is a good idea, but the 2 -for-1 requirement seems superfluous."). For some supportive thoughts on the framework from a conservative analyst who subsequently served in the Trump Administration, see Marcus Peacock, Implementing a Two-for-One Regulatory Requirement in the U.S. (Geo. Wash. Univ. Reg. Stud. Ctr. Working Paper, Dec. 7, 2016), http://regulatorystudies.columbian.gwu.edu/sites/ regulatorystudies.columbian.gwu.edu/files/downloads/Peacock_Implementing-Two-For-One\%20122016_final.pdf [http://perma.cc/Q22K-CPEV]; see also Sam Batkins, It Is Premature To Label a Regulatory Budget Unconstitutional, REG. REV. (June 26, 2017) (defending the two-for-one rule), $\mathrm{http}: / / \mathrm{www}$.theregreview.org/2017/06/26/batkins-premature-regulatory-budget-unconstitutional [http:// perma.cc/9YR5-QREL].

324. See Peter Shane, The GOP's Radical Assault on Regulations Has Already Begun, WASH. MONTHLY (Feb. 27, 2017), http://washingtonmonthly .com/2017/02/27/the-gops-radical-assaulton-regulations-has-already-begun/ [http://perma.cc/96KF-KP9B] (arguing that, without legislation, "the Trump executive order cannot legally be implemented .... When Congress directs an agency to issue regulations to address a particular problem, the factors that legally count as 'relevant' include issues Congress itself identifies for agency concern and any other factors logically relevant to implementing the statute at hand .... What isn't legally relevant in evaluating a new proposed regulation is whether there are two old ones available to trash. There is no regulatory statute authorizing any agency to take that into 
statute compels adoption of the repealed rule, the administrative law violation is even more obvious, for the repeal itself-rather than just its reasoning-violates a statute. An executive-imposed regulatory budget may be largely invalid for similar reasons. ${ }^{325}$ In both instances, statutory imposition of these requirements by Congress would not be legally problematic. But because these orders are at cross-purposes with the statutes under which many agencies operate, their effects may be limited. Only time will tell if the federal courts agree. As a political matter, they may be more effective. Policy challenges to OMB by line agencies are hazardous to a political appointee's continued membership in the administration.

It is thus too early to judge the impact of President Trump's boldest regulatory orders. The rescission process for promulgated rules is, in many areas of the law, fraught enough with litigation risk that the lasting scope of Trump's success will be determined in the months and years to come. It is fair to say, putting aside these process changes, that the Trump Administration has been quite successful in forms of regulatory control that do not require repeal of promulgated rules.

In particular, Trump and his administrators have been immensely successful in their repeal of specific pro-regulatory guidance not embodied in formal rules (and so much more easily rescinded) and their control of government information and messaging that could be inimical to Trump's agenda. ${ }^{326}$ In terms of rescinding informal guidance, a full catalogue of examples would be too large to provide here, but the Trump Administration has already rescinded policies ranging from the Obama Administration's calculation for how agencies consider the social cost of carbon ${ }^{327}$ to the Administration's interpretation of civil rights laws to protect transgender rights. ${ }^{328}$ In terms of information control, the best example is environmental science, where the Trump Administration made early moves to clamp down on the scientific data and conclusions coming out of the EPA and elsewhere. ${ }^{329}$ The EPA took down a

account .... An agency explaining that its repeal of Rule A was necessary to secure OMB approval to promulgate Rule B would be laughed out of court ....").

325. E. Donald Elliott, President Trump Establishes Regulatory Budgets by Executive Order, INSIDE ENERGY \& ENV'T (Feb. 1, 2017), http://www.insideenergyandenvironment.com/2017/02/ president-trump-establishes-regulatory-budgets-by-executive-order [http://perma.cc/K6BK-93FM] ("[I]n the past, establishing a regulatory budget has generally been thought to require legislation.").

326. E.g., Nadja Popovich \& Tatiana Schlossberg, 23 Environmental Rules Rolled Back in Trump's First 100 Days, N.Y. TIMES (May 2, 2017), http://www.nytimes.com/interactive/2017/05/02/ climate/environmental-rules-reversed-trump-100-days.html [http://perma.cc/S3E2-XGNN].

327. Exec. Order No. 13,783, 82 Fed. Reg. 16,093, 16,095 5 (Mar. 31, 2017).

328. Dep't of Justice \& Dep't of Educ., Dear Colleague Letter (Feb. 22, 2017), http://www.justice.gov/opa/press-release/file/941551/download [http://perma.cc/YX82-YKK3]; see Charlie Savage, Justice Dept. Revokes 25 Legal Guidance Documents Dating to 1975, N.Y. TIMES (Dec. 21,2017), http://www.nytimes.com/2017/12/21/us/politics/justice-dept-guidance-documents.html [http:// perma.cc/XA3U-XDDN]

329. See Michael Biesecker \& Seth Borenstein, EPA Science Under Scrutiny by Trump Political Staff, ASSOCIATED PRESS (Jan. 26, 2017), http://bigstory.ap.org/article/ c1423276fb574b07953651a68a082db9 [http://perma.cc/8XYP-5WRQ]; Joel Clement, Opinion, I'm $a$ 
climate website that provided scientific climate data that had been available and used by climate researchers and others for twenty years. ${ }^{330}$

While executive action has quickly shifted regulatory guidance and information practices, those practices could just as quickly shift again if Trump is denied a second term. But other deregulatory successes-accomplished within an extremely short time period-are more durable due to legislation made possible by unified government. ${ }^{331}$

Specifically, the Republican-controlled Congress has used the Congressional Review Act (CRA) ${ }^{332}$ to repeal numerous major rules passed during the final months of the Obama Administration. ${ }^{333}$ The CRA permits Congress to pass joint resolutions to disapprove of rules that administrative agencies have recently promulgated. ${ }^{334}$ If the President approves (or Congress overrides his veto), the rule is voided. The CRA has been around for about twenty years, and before this year, Congress had only once successfully used it to void a rule. ${ }^{335}$

The CRA is quiescent no more. Congress and President Trump collaborated to use the CRA to quickly void major Obama-era rules on issues from internet privacy to coal mining debris, as well as a rule to prevent the mentally disabled from purchasing firearms. ${ }^{336}$ Later, Congress used the CRA to void the CFPB's

Scientist. I'm Blowing the Whistle on the Trump Administration, WASH. POST (July 19, 2017), http:/www.washingtonpost.com/opinions/im-a-scientist-the-trump-administration-reassigned-me-forspeaking-up-about-climate-change/2017/07/19/389b8dce-6b12-11e7-9c15-177740635e83_story.html [http://perma.cc/U8DT-BTTX].

330. Chris Mooney \& Juliet Eilperin, EPA Website Removes Climate Science Site from Public View After Two Decades, WASH. POST (Apr. 29, 2017), http://www.washingtonpost.com/news /energy-environment/wp/2017/04/28/epa-website-removes-climate-science-site-from-public-view-aftertwo-decades/ [http://perma.cc/3Y8Z-UVCR]; see also Coral Davenport \& Eric Lipton, Scott Pruitt Is Carrying Out His E.P.A. Agenda in Secret, Critics Say, N.Y. TIMES (Aug. 11, 2017) http:// www.nytimes.com/2017/08/11/us/politics/scott-pruitt-epa.html (describing Pruitt's practices at the EPA),

331. See Juliet Eilperin, Trump Undertakes Most Ambitious Regulatory Rollback Since Reagan, WASH. POST (Feb. 12, 2017), http://www.washingtonpost.com/politics/trump-undertakes-mostambitious-regulatory-rollback-since-reagan/2017/02/12/0337b1 f0-efb4-11 e6-9662-

6eedf1627882_story.html [http://perma.cc/TY6J-6M99].

332. 5 U.S.C. $\S \S 801-08(2018)$

333. For a tracker of CRA resolutions, see CRA Tracker, GEO. WASH. REG. STUD. CTR., http://regulatorystudies.columbian.gwu.edu/sites/regulatorystudies.columbian.gwu.edu/files/downloads/ CRA\%20Tracker\%2004-13-2017\%2B.pdf [http://perma.cc/PD5N-7ANQ].

334. See MAEVE P. CAREY ET AL., CONG. RES. SERV., R43992, THE CONGRESSIONAL REVIEW ACT: FREQUENTLY ASKED QUESTIONS (Nov. 17, 2016), http://fas.org/sgp/crs/misc/R43992.pdf [http://perma.cc/5WBJ-FSDV].

335. The Bush-era Congress nullified the Labor Department's ergonomics rule, which was formulated under President Clinton. Ergonomics Rule Disapproval, Pub. L. No. 107-5, 115 Stat. 7 (2001); see also Ergonomics Program, 65 Fed. Reg. 68,262 (Nov. 14, 2000) (providing the final text of the rule, prior to congressional nullification). Indeed, its use was so infrequently successful that the CRA served as a minor novelty item on the syllabi of American administrative law courses.

336. Kevin Freking, GOP Congress Rolls Back Rules on Hunting, Broadband Privacy, ASSOCIATED PRESS (Apr. 2, 2017), http://bigstory.ap.org/article/0d6cc7d8ca484a93a8d76b4571000771/ gop-congress-rolls-back-rules-hunting-broadband-privacy [http://perma.cc/UM7G-Q8T5]. 
rule against mandatory arbitration, ${ }^{337}$ which showed a dynamic interplay between an administrative agency intended to be more independent and Congress" political control. These CRA resolutions were "a historic reversal of government rules in record time." 338 As other GOP legislative efforts have sputtered, these CRA repeals "arguably constitute the Trump Administration's chief domestic policy accomplishment of its first 100 days." ${ }^{339}$ Although it is hard to tell, this CRA effort was seemingly effected through collaboration between the President and Congress, ${ }^{340}$ even if not all CRA resolutions were ultimately successful. ${ }^{341}$

Of course, the Trump Administration could, arguably, rescind these promulgated rules itself, without congressional assistance, but CRA resolutions are far more potent than executive rescission. Rescission of rules is generally a lengthy, public and participatory process, subject to the same searching judicial review as when rules are promulgated. ${ }^{342}$ By contrast, the CRA allows for revocation based on a simple up-or-down vote (assuming the President accedes) under expedited procedures that give the resolutions agenda priority and eliminate Senate filibusters. A formal administrative rescission could take months or years and require hundreds (if not thousands) of pages of factual findings and agency justification. A CRA resolution requires no factual record or stated rationale and can be just one sentence. ${ }^{343}$ And, unlike executive rescission, CRA resolutions are immune from judicial review. ${ }^{344}$

337. Renae Merle \& Tory Newmyer, Congressional Republicans Use Special Manuever [sic] To Kill 'Arbitration Rule', WASH. POST (Oct. 25, 2017), http:/www.washingtonpost.com /business/economy/once-again-congressional-republicans-find-it-easier-to-kill-policy-than-writeit/2017/10/25/06eb764e-b997-1 le7-be94-fabb0fle9ffb_story.html [http://perma.cc/M9HB-VW9Z].

338. Michael D. Shear, Trump Discards Obama Legacy, One Rule at a Time, N.Y. TIMES (May 1, 2017), http://www.nytimes.com/2017/05/01/us/politics/trump-overturning. regulations.html [http://perma.cc/A52P-993J].

339. Stuart Shapiro, Will Congressional Review Act Repeals Change Agency Behavior?, REG. REV. (Apr. 3, 2017), http://www.theregreview.org/2017/04/03/shapiro-congressionalreview-act-agency-behavior [http://perma.cc/6GAA-TK5R].

340. Shear, supra note 338.

341. See Coral Davenport, In Win for Environmentalists, Senate Keeps an Obama-Era Climate Change Rule, N.Y. TIMES (May 10, 2017), http://www.nytimes.com/2017/05/10/us/politics/ regulations-methane-climate-change.html [http://perma.cc/UXR7-PWCK] (describing failed Congressional Review Act resolution that attempted to void an Obama-era methane regulation, although the regulation can still be rescinded by the Interior Department). However, even though this methane rule survived the CRA, Trump's Interior Department has already moved to delay and likely ultimately eliminate it. See Waste Prevention, Production Subject to Royalties, and Resource Conservation; Postponement of Certain Compliance Dates, 82 Fed. Reg. 27,430 (June 15, 2017), http://www.gpo.gov /fdsys/pkg/FR-2017-06-15/pdf/2017-12325.pdf [http://perma.cc/M478-NPDM].

342. See Motor Vehicle Mfrs. Ass'n of U.S. v. State Farm Mut. Auto. Ins. Co., 463 U.S.

29 (1983).

343. 5 U.S.C. $\$ 802$ (a) (2012).

344. Id. $\S 805$ ("No determination, finding, action, or omission under this chapter shall be subject to judicial review."). To the extent litigants have attempted to assert claims under the CRA, they have claimed that existing agency rules are invalid because they were not properly submitted to Congress as the CRA requires. These claims have had limited success. See CAREY ET AL., supra note 334, at 18-20. A claim against a successful CRA resolution would be even more tenuous. 
Moreover, if the Trump Administration merely rescinded the rule, a future Democratic administration could re-promulgate it. A successful CRA resolution precludes the promulgating agency from ever again issuing a rule "in substantially the same form" unless Congress affirmatively authorizes the rulemaking. ${ }^{345}$ The agency suffers a loss of regulatory power that a future President, acting through the relevant agency, cannot reverse. ${ }^{346}$

President Trump's early presidency has also been notable for how he has used (and avoided) the appointments power to further his agenda. The basic story is his strong and successful focus on appointing executive officers who are fiercely loyal to his domestic deregulatory policies, perhaps best exemplified by his nomination of Scott Pruitt to head the EPA. ${ }^{347}$ That aspect of Trump's presidency is similar to how Kagan describes Reagan's appointments. ${ }^{348}$ However, there is greater nuance to Trump's appointments practiceparticularly (i) his (now seemingly failed) attempt to install a sort-of shadow cabinet to monitor the loyalty and progress of his various appointees and (ii) the notably slow pace of his appointments to sub-cabinet secretary positions. ${ }^{349}$

To start with the headline, Trump's deregulatory push has, thus far, been successful in part because his appointed cabinet secretaries, or at least the ones who have survived, are so loyal to the cause. ${ }^{350}$ Indeed, in his picks, Trump has put a particular emphasis on not just ideological but personal loyalty, appointing people-like Attorney General Jeff Sessions, HUD Secretary Ben Carson, and Treasury Secretary Steve Mnuchin-who showed him the strongest political loyalty during his presidential campaign. With some exceptions, like Energy Secretary Rick Perry, ${ }^{351}$ criticism of Trump during the campaign has generally been grounds for rejection or dismissal of appointees and their staff. ${ }^{352}$ With this blend of personal and ideological loyalty, the legal question of presidential

345. 5 U.S.C. $\$ 801(\mathrm{~b})(2)$.

346. There is, however, dispute about the scope of this restriction, as well as how courts would review agency compliance.

347. See supra Section IV.B.2.

348. Kagan, supra note 21, at 2277.

349. This latter inaction may be the true face of Trumpian "deconstruction."

350. Donald Trump's Cabinet is Almost Complete. Here 's the Latest List., N.Y. TIMES (Apr. 27, 2017), http://www.nytimes.com/interactive/2016/us/politics/donald-trump-admin istration.html [http://perma.cc/3CEU-J7WH].

351. Adam Howard, Rick Perry: Trump's Candidacy a 'Cancer on Conservatism,'MSNBC (July 23, 2015, 8:12 AM), http://www.msnbc.com/msnbc/rick-perry-trumps-candidacy-cancer-conservatism [http://perma.cc/B2ZN-BKFF] ("Former Texas Gov. Rick Perry called Donald Trump's politics 'toxic' and his 2016 candidacy a 'cancer' on conservatism . . . .").

352. See Lisa Rein, Slow Pace of Trump Nominations Leaves Cabinet Agencies 'Stuck' in Staffing Limbo, WASH. POST (Apr. 25, 2017), http://www.washingtonpost.com/politics/slow-pace-oftrump-nominations-leaves-cabinet-agencies-stuck-in-staffing-limbo/2017/04/25/0a 150aba-252c-1 le7b503-9d616bd5a305_story.html [http://perma.cc/ 8FAW-S6NZ] (discussing rejection of Elliott Abrams as Deputy Secretary of State based on his Trump criticism); Maggie Haberman \& Yamiche Alcindor, $A$ HUD Official Once Criticized Trump. Now He's an Ex-Official., N.Y. Times (Feb. 16, 2017), http:// www.nytimes.com/2017/02/16/us/politics/shermichael-singleton-housing-urban-development.html [http://perma.cc/T3WA-ZNMH]. 
directive authority is often beside the point, since the directive authority is valid as a political and social matter.

However, that does not mean there is an absolute unity between the President and his appointees. Early on, a key point of tension was Trump's installation of administration loyalists at various agencies to monitor political appointees' compliance with administration priorities, what Politico called his "shadow Cabinet." 353 These "shadow" advisors-who are not subject to Senate confirmation, and are allegedly selected more for political allegiance than policy expertise-were installed at each agency but report directly to senior White House policy advisors in the EOP. As one source put it, the White House "want[s] to keep kind of a West Wing-infused attachment to the agencies .... The effort is to demonstrate that all points lead back to" the EOP. ${ }^{354}$ Politicallydriven White House liaisons at agencies are not new (witness Obama's aggressive use of policy czars), but the high-level access of these Trump liaisons, both within the EOP and the agencies in which they are installed, is novel..$^{355}$

Given the seeming loyalty of Trump's appointed agency heads, this shadow Cabinet may seem superfluous. But the Trump EOP seemed to believe that, because Trump "does not have long-standing relationships" with many of his top appointees, monitoring was necessary. ${ }^{356}$ Also, as a senior Trump official put it, "[a] lot of these [Cabinet heads] have come from roles where they're the executive ... But when you become head of an agency, you're no longer your own person."357 But presidential control of administration is not so straightforward, even with ideologically aligned and personally loyal appointees. Scott Pruitt was allegedly so frustrated with his White House liaison that Pruitt banished him from many meetings. ${ }^{358}$ Pentagon leadership derisively referred to their liaison as "the commissar." 359

Under pressure from appointees, the Trump EOP seemingly relented on its shadow cabinet. It began "dismantling" the network of liaisons, after "tensions .. . escalated for weeks." "360 Apparently, "many" of the liaisons "had expected to be central players at their agencies for the long haul," $" 361$ but appointees managed

353. Josh Dawsey \& Nancy Cook, Trump Assembles a Shadow Cabinet, Politico (Jan. 24, 2017), http://www.politico.com/story/2017/01/trumps-shadow-cabinet-234088 [http://perma.cc/ 7GU9-D9NJ].

354. Id.

355. Id.

356. Lisa Rein \& Eilperin, White House Installs Political Aides at Cabinet Agencies To Be Trump's Eyes and Ears, WASH. POST (Mar. 19, 2017), http://www.washingtonpost.com/powerpost/ white-house-installs-political-aides-at-cabinet-agencies-to-be-trumps-eyes-and-ears/2017/03/19/ $68419 \mathrm{fOe}-08 \mathrm{da}-11 \mathrm{e} 7-93 \mathrm{dc}-00 \mathrm{f} 9 \mathrm{bdd} 74 \mathrm{ed} 1$ story.html [http://perma.cc/3J6J-N25Z].

357. Id.

358. Id.

359. Id

360. Michael Grunwald et al., Trump Starts Dismantling His Shadow Cabinet, POLITICO (May 1, 2017, 5:09 AM), http:/www.politico.com/story/2017/05/01/trump-starts-dismantlinghis-shadow-cabinet-237819 [http://perma.cc/9S96-VDH7].

361. Id. 
to convince the EOP to end the program. One imagines that this concession to appointees had more to do with the pride and self-worth of agency heads than their legal understandings of their administrative authority vis-à-vis the President. For all the constitutional and administrative theory that is trained on presidential administration, these relationships are still socially textured. Agency heads may heed the President's directives, but as a matter of professional selfesteem, appointees do not want to be subject, day-to-day, to overbearing minders.

Trump's appointed administrators also seemed frustrated at the notably slow pace of Trump's appointments to sub-cabinet positions that require Senate confirmation. ${ }^{362}$ The Administration explained the high number of vacancies in appointed positions by saying the absence of appointees is deregulatory since it immediately shrinks government in itself, but that seems like a tenuous rationalization. Many aspects of Trump's deregulatory drive have been successful, but slow staffing is not one of them. Indeed, this failure to staff political appointments likely frustrated Trump's agenda. The civil service personnel that end up managing these responsibilities are generally quite hostile to Trump's agenda. ${ }^{363}$

\section{Some Preliminary Assessments}

In terms of the theories of presidential administration that frame this Article, the developments concerning the structure of the administrative state suggest several summary observations. First, presidential administration has moved forcefully into areas where Kagan cautioned against executive intervention. Second, politically unified government has clearly had an impact in rolling back regulations that were adopted within the CRA window. And finally, presidentialist policy durability seems to hinge crucially on the institutionalization of presidential (or EOP) controls.

Last point first: in Kagan's descriptive explanation of presidentialism, the rise of the OIRA process was central, both under Reagan and Clinton. ${ }^{364}$ And, that process remained essentially the same under Obama as it was under Clinton.

362. Rein, supra note 352; Peter L. Strauss, Trump Administration Appointments, TAKE CARE (Apr. 4, 2017), http://takecareblog.com/blog/trump-administration-appointments [http://perma.cc /H9EM-PVBQ].

363. See Mark Landler, Some U.S. Diplomats Stage Quiet Revolt Amid Tensions with Trump, N.Y. TIMES (June 5, 2017), http:/www.nytimes.com/2017/06/05/us/politics/diplomats-quietrevolt-donald-trump-tensions.html [http://perma.cc/8YSC-2XV2]; Michael D. Shear \& Eric Lichtblau, 'A Sense of Dread' for Civil Servants Shaken by the Trump Transition, N.Y. TIMES (Feb. 11, 2017), http://www.nytimes.com/2017/02/11/us/politics/a-sense-of-dread-for-civil-servants-shaken-by-trumptransition.html [http://perma.cc/VK46-JXXS]; Juliet Eilperin et al., Resistance From Within: Federal Workers Push Back Against Trump, WASH. POST (Jan. 31, 2017), http://www.washingtonpost.com /politics/resistance-from-within-federal-workers-push-back-against-trump/2017/01/31/c65b110e-e 7cb11 e6-b82f-687d6e6a3e7c_story.html [http://perma.cc/2MBZ-4Z4M]. As discussed above, certain agencies like ICE are exceptions. See supra Section IV.A.2.

364. Kagan, supra note 21 , at 2277-80, 2285-90. 
Where Obama made changes was in how various costs and benefits, like the cost of carbon, were weighted in agency regulatory impact analyses and OIRA review. Trump has thus far attempted to remake the OIRA process through the 2 -for- 1 rule and the imposition of regulatory budgets. It remains to be seen how successful these changes will be, but the "one-way ratchet" of executive control may have moved even further in favor of executive authority. ${ }^{365}$ We have suggested that these innovations are of problematic legality. But beyond those legal issues, Trump's aggressive assertions of regulatory control could signal the end of relatively bipartisan acceptance of the OIRA/cost-benefit process, which remained largely unchanged in form from 1993 through 2016. Muscular presidentialism can invite reaction rather than imitation.

Next, we have the compelling contrast of Obama's czars with Trump's shadow cabinet. One imagines that both these tools for presidential control of the regulatory state are normatively desirable from a presidentialist perspective. Assuring effectiveness is the principal value in play. But both mechanisms serve to remove Congress from high-level personnel decisions in the administrative state. As for the shadow cabinet, it could have allowed the President to appoint agency heads that appear more independent and palatable to Congress, but then somewhat clandestinely tether them to day-to-day EOP supervision. The shadow cabinet system is thus, perhaps, a way to avoid appropriative accountability for just how much the White House manages the administrative state. At least czars tend to be relatively public positions, if often unconfirmed. What is perhaps concerning is that the shadow cabinet seemingly did not fail because it was shadowy, but because it conflicted with the professional self-esteem of appointees.

This case study also reveals both Obama and Trump moving presidential administration into areas where Kagan was uncomfortable with overly assertive presidential authority. Kagan expressed a hesitancy about presidentialism seeping into prosecution (as opposed to regulatory policymaking), ${ }^{366}$ but Obama's white-collar enforcement ramp-up and Trump's deportation guidance move precisely in that direction. Trump's climate-science interventions at the EPA are again the types of political interventions in government science that Kagan warned against. ${ }^{367}$ And the intensity of the Trump Administration's efforts in this regard seem exponentially more aggressive than those during the second Bush Administration. Electoral accountability is not working to prevent this practice, and this information control is hardly democracy reinforcing.

On separation of powers, the GOP's interbranch success with the CRA aligns with the Levinson-Pildes thesis. ${ }^{368}$ In a unified government, the CRA has

365. SHANE, supra note 48, at 114; Reconcevert Almond et al., Regulatory Reform in the Trump Era-The First 1000 Days, 35 YALE J. ON REG. BULL. 29 (2018).

366. Kagan, supra note 21, at 2357-58.

367. Id. at 2356-57.

368. Levinson \& Pildes, supra note 1. 
allowed Trump to supercharge his deregulatory efforts against late Obama Administration regulations. The CRA makes these rescissions, immediate, judicially unreviewable, and fairly permanent. However, perhaps other experiences under Trump illustrate that the "separation of parties" thesis is only a partial account, a thread in a more complex tapestry. Institutional differences have still manifested in key areas. Congressional Republicans essentially abandoned most of the Trump Administration's core spending priorities for a recent budget resolution in favor of bipartisan collaboration within the legislature. ${ }^{369}$ And attempts to use the CRA against the Obama Administration's methane rule failed. ${ }^{370}$

Lastly, the Trump experience shows how presidential administration can, as it grows stronger, cancel itself out across administrations. Even putting aside Trump's legally suspect regulatory process changes and failed shadow cabinet, when one combines Trump's other deregulatory strategies-information control and rescission of sub-regulatory guidance, the CRA, and sharply conservative appointments-one sees that Obama's major regulatory accomplishments are, for the most part, ${ }^{371}$ gutted or on the road to being gutted. It will take time to rescind certain of his Administration's promulgated rules that are beyond the CRA's reach. And efforts to do so may fail. But we predict that the Trump Administration will ultimately be mostly successful in eliminating or mitigating the effects of these rules through the exercise of administrative enforcement discretion. The President's ability to control administration has become sufficiently powerful that erasing a prior Administration requires little more than determination - and perhaps a dash of ruthlessness.

\section{Conclusion}

We have offered some theoretical reflections on our case studies as we have presented them, finding: continued bold attempts to accrete executive power beyond Clinton-era presidentialism, an extension of what Shane observed during the Bush II Administration; presidential administration insinuating itself more and more into areas where Kagan cautioned against aggressive presidentialism, such as prosecution/adjudication and government science; and the rise of organizational techniques, such as policy czars and "shadow cabinets," to codify

369. Hulse, supra note 251 .

370. See Davenport, supra note 341; Postponement of Certain Compliance Dates, 82 Fed. Reg. 27,430 (June 15, 2017), http://www.gpo.gov/fdsys/pkg/FR-2017-06-15/pdf/2017-12325.pdf [http://perma.cc/M478-NPDM].

371. But see Tara Siegel Bernard, Obama's Fiduciary Rule, After a Delay, Will Go into Effect, N.Y, TIMES (May 23, 2017), http://www.nytimes.com/2017/05/23/business/obamas-fiduciaryrule-after-a-delay-will-go-into-effect.html [http://perma.cc/ M9YE-G4LP] (describing how Trump's Department of Labor decided to allow a major Obama consumer protection rule for retirement savings to go into effect); Strauss, supra note 129, at 15-16. However, aspects of the fiduciary rule seem destined for elimination. See Extension of Transition Period and Delay of Applicability Dates, 82 Fed. Reg. 41,365 (Aug. 31, 2017), http://www.gpo.gov/fdsys/pkg/FR-2017-08-31/pdf/2017-18520.pdf [http://perma.cc [Z69G-4XN3]. 
presidential control beyond episodic directive authority. Our case studies also suggest a judicial anxiety with broadening presidential exercises of domestic authority. But recent judicial opinions cabining aspects of that authority have sometimes employed questionable reasoning from the perspective of standard administrative law doctrine. This shaky foundation reveals that the capacity of judicial review to check presidentialism is modest.

We also see a general lack of durability for presidential policy actions across these two Administrations. Indeed, the speed with which presidential administration in the Obama era has been undone in the early Trump Administration has proven, in many instances, impressive. Pluralist skepticism of presidential authority has, at least in some respects, had certain of its premises vindicated. Indeed, certain passages from Madison's Nightmare provide uncannily prescient descriptions. However, even as both sides of the political spectrum claim executive overreach by the other, with minor libertarian exception, neither side advocates or enacts a broad scaling back of executive power. Even if recent political developments have demonstrated potentially serious blind spots and the risks of Kagan-esque presidentialism as a framework for American government, both liberals and conservatives have essentially accepted it, to perhaps a greater extent than ever before.

Now, we pull back from specific policy realms to think more broadly about the Obama and Trump experiences. We begin with the continuing normative worth of presidentialism. This recent experience leaves us with a tempered view. We then turn to separation-of-powers theory. While one certainly cannot comprehend the function of American government without the "separation of parties" perspective, we still see a real and important role for institutional separation of powers, broadly understood to include judicial imposition of congressional prerogatives and a healthy role for the federal bureaucracy in shaping presidential administration.

Presidentialism as a Practice. We do not believe that presidential administration-meaning, presidential exercises of constitutionally legitimate executive power to shape implementation of the law-is either new or nefarious. The Constitution, after all, charges the President with the duty to see that the laws are faithfully executed. Moreover, the Founders made the deliberate decision to make the executive power "unitary," in the sense that a single executive exercises that power rather than a council, which was the widelycriticized practice in some states. ${ }^{372}$ And the very first Congress affirmed, if somewhat obliquely, that the President would not need senatorial advice and consent to remove presidential appointees. ${ }^{373}$ It was also the practice of early congresses to delegate authority in a substantial number of instances to the

372. MASHAW, supra note 2, at 31.

373. Id. at 39 . 
President himself, with the understanding that the President had the authority to sub-delegate to other administrative officials. ${ }^{374}$

Over time, congressional enthusiasm for presidential administration has waxed and waned, as evidenced by the ways in which Congress has structured various agencies and departments. On the waning side, even the first Congress was jealous of its own authority with respect to the Treasury. ${ }^{375}$ And over time, as governmental administrative capacities grew, Congress delegated more and more authority directly to departments and agencies. While Congress gave President Franklin Roosevelt much of what he wanted substantively in New Deal legislation, many New Deal agencies were set up as multi-member, independent commissions with limitations on the President's power of removal. This "new and headless 'fourth branch' of government" as President Roosevelt's Administration termed it, ${ }^{376}$ was less under presidential and more under congressional control.

But the independent commission form proved disappointing from the standpoint of energy and effectiveness. The outpouring of new legislation in President Johnson's Great Society era avoided the commission form in structuring important health and safety agencies like the EPA, the Occupational Safety and Health Administration (OSHA), and the National Highway Traffic Safety Administration (NHTSA). Congress also clearly promoted presidentialism when it created the OMB as a central administration clearinghouse for both budget proposals and proposed legislative changes emanating from existing agencies and departments. Just as George Washington leveraged executive power by demanding to see and clear all correspondence of his department heads, ${ }^{377} \mathrm{OMB}$ has leveraged its budgetary control to screen congressional testimony and, beginning with the Reagan's EO $12,291,{ }^{378}$ to review agency policy in the form of proposed major rules.

While both the Obama and Trump Administrations have been aggressive in their use of presidential power to shape administrative policy, they have, at least to a certain extent, acted within these American constitutional traditions. Whether those traditions are good or bad has been (and remains) hotly contested. Developing neutral criteria for evaluating exercises of presidential administration is not easy. Most arguments for and against are highly influenced by agreement or disagreement with the substance of administration policy.

374. Id. at 292. But see David M. Driesen, Toward a Duty-Based Theory of Executive Power, 78 FORDHAM L. REV. 71, 82 (2009) ("The Framers . . did not expect the President to act as a policy maker in executing the law ... . They viewed Congress as the chief policy maker and viewed the President as the 'Chief Magistrate,' i.e., as the principal officer who must obey and properly carry out the law.").

375. MASHAW, supra note 2, at 40-42.

376. PRESIDENT'S COMM. ON ADMIN. MGMT., ADMINISTRATIVE MANAGEMENT IN THE GOVERNMENT OF THE UNITED STATES 29 (1937), http://catalog.hathitrust.org/Record/001 141809 [http:// perma.cc/3CAM-PZH2].

377. MASHAW, supra note 2, at 55.

378. Federal Regulation, Exec. Order No. 12,291, 3 C.F.R. 127 (1981). 
Kagan sought to evaluate presidential administration from the standpoint of both energy and accountability. And while she gives presidential administration high marks on both criteria, actions by Obama Administration officials and actions taken in the early Trump Administration raise important questions about that analysis.

Presidentialism, Energetic Administration and Democratic Accountability. The energy point is intuitively attractive and dates back at least to Alexander Hamilton's analysis in the Federalist Papers. ${ }^{379}$ And, the Obama years certainly saw multiple uses of presidential executive power to set and promote administrative agendas that were then carried forward by the agencies and departments having the relevant statutory authorities. But formal presidential control is not necessarily the main driver of agency initiatives. The CFPB was arguably one of the most energetic agencies during the Obama years, but the CFPB's statutory restrictions on the President's removal power caused its structure at first to be ruled unconstitutional, though later upheld. ${ }^{380}$ Moreover, there may be a sense in which a President's priorities energize particular agencies while neglecting others whose powers atrophy. While the EPA and the Energy Department have been extremely active with respect to environmental and climate change policies, there is little evidence of energetic action at agencies like OSHA or NHTSA.

Indeed, energy is a rather vague standard by which to evaluate administration. Was President Obama's DACA and DAPA policy energetic when it "de-energized" immigration enforcement? Are President Trump's directives to multiple agencies to reconsider and perhaps amend or rescind Obama-era regulations a sign of energetic government, or rather an attempt to make government less active in regulating private activity? If energy means simply promoting policy change, then perhaps all these initiatives are "energetic." But that tends to call into question whether energy should be understood as normatively attractive.

This question is particularly relevant when one also considers policy durability, as this Article has. In that context, "energy" comes to seem like a Sisyphean doing and undoing of the same policies-an expensive repetition that thwarts the policy goals motivating both the enactment and rescission. As a preliminary matter, surely we would at least want to substitute something like "energetic in carrying out statutory responsibilities as reasonably interpreted, respectful of constitutional liberties and limits on government power" into the simple question of whether administration has been "energetic." That standard puts in question the substance of presidential policy initiatives, not just whether,

379. THE FEDERALIST No. 70, at 447 (Alexander Hamilton) (Modern Library ed., 2000) ("Energy in the Executive is a leading character in the definition of good government.").

380. PHH Corp. v. CFPB, 839 F.3d 1 (D.C. Cir. 2016), vacated and remanded, 881 F.3d 75 (D.C. Cir. 2018) (en banc). 
at the President's direction, lots of presidentially inspired policies were zealously implemented.

Accountability is equally difficult to evaluate. There are certainly strong arguments for electoral accountability enhancement through presidential administration. The cumbersomeness of the legislative process means that American federal statutes tend to be relatively sticky. With some amendment, they persist over decades, while circumstances on the ground and electoral preferences shift more rapidly. That a President could make good on electoral promises by influencing administrative policymaking makes presidential elections something more than a mere beauty contest. On the other hand, voters also vote retrospectively. And here, as Kagan notes, electoral accountability depends significantly on the transparency of administrative actions and the effectiveness of media coverage in informing voters about administrative policy and the likely effects of administrative action. ${ }^{381}$

Shane surely has a point when he notes that transparency is often within the control of the administration. But neither President Obama nor President Trump have been bashful about appropriating policy positions that must be carried out by agencies and departments that in fact have the statutory authority to act. To that degree, appropriation promotes transparency. This has been true in both administrations, even in areas of enforcement policy where presidentialism can take much more subterranean forms. At the macro level, American voters can hardly be confused concerning the differences in Obama Administration and Trump Administration policies with respect to environmental, energy, and immigration matters. That these Presidents appropriated or instigated these policy changes or initiatives certainly enhanced media coverage and, therefore, public understanding of what the government's policies were.

On the other hand, Shane is surely correct that administrations have considerable flexibility concerning their transparency policies at more detailed levels that are still of interest to voters (e.g., who really participated in decisionmaking, whose interests are being served by particular policy initiatives, and what information the administration has deemed relevant to decision-making).

Finally, it should be noted that to the degree that administration action is motivated by political considerations emanating from the White House, there is a necessary loss of transparency compared with agency action carried out through normal administrative procedures. Particularly with respect to major policy initiatives, the agency rulemaking process is radically transparent. Rulemaking participation and records are open to all, and agencies may not justify their policies on the basis of any considerations outside of the rulemaking records. The enunciation of undisclosed "national security" or counter-terrorism concerns in the "travel ban" would not for a moment sustain an agency rule to the same effect. 
Shane also has a point that media coverage is episodic and sometimes misinformed. Our media landscape may now be so fractured that most citizens receive their news from outlets that largely reinforce their preexisting preferences or prejudices. On the other hand, widespread criticism of President Obama's use of administrative authority, in domains where legislation premised on similar or identical policies had failed, tended to weaken support for both his immigration and clean power policies. And the consistent drumbeat of negative coverage of the early Trump Administration is taking its toll, at least for now, on that Administration's popularity and perceptions of its competence. Moreover, it is far from obvious that the media would be less factional, or anti-factual, in a pluralist system as opposed to a presidentialist one. Further, presidentialism makes media-based accountability relatively easier.

There is, however, a somewhat different and perhaps deeper problem with the idea that presidential administration promotes democratic accountability. Presidential administration tends by its very nature to limit the actors who are engaged in policy discussions and conceal the real motivations and considerations behind the administrative policies. White House czars and OMB oversight operate outside of the procedural requirements of the APA and other statutes imposing participatory and transparency demands on agency processes. Agencies must give reasons for their policies adopted by rule or through adjudicatory processes. Those reasons must be related closely to the record formed in their proceedings, and salient submissions by those who object must be countered by cogent arguments-or at least arguments acceptable to reviewing courts. Agency rulemaking processes are arguably the most open and deliberative of any processes in American federal governance. And to that degree, presidential administration is antithetical to the democratic accountability that deliberative democrats view as a necessary justification for the exercise of governmental power. Indeed, if we believe that electoral accountability is necessarily weak at the micro level of policy detail, presidentialism tends to short-circuit or undercut the deliberative processes that make agency decision-making democratically accountable.

These considerations suggest that evaluating presidential administration normatively is a subtle business. Presidentialism that takes account of process and participatory values; is transparent and robust concerning sources, science, and data consulted or relied upon; that provides justificatory reasoning that connects policies to statutory missions and criteria; and that respects legislative prerogatives and the embedded information advantages of line agencies, is, from our perspective, good government. ${ }^{382}$ Failure to abide by these conventions, while sometimes justified, is generally problematic and anti-democratic. Indeed, in light of recent experience, unitarian theory that bristles at these constraints and pushes beyond presidentialism seems both dangerous and excessive. On these

382. For a recent, illuminating discussion on the important of such "procedural legitimacy," see Chen, supra note 188 , at 358 . 
criteria, both the Obama and early Trump administrations are open to justifiable complaint. However, the Obama Administration's approach was far more like government as usual, in these normatively desirable respects.

Separated Powers or Separated Parties? In our view, Professor Cane's rather modest claim that overall regime structure influences the control of administrative power is more justified than the Levinson-Pildes argument that separation of powers without separation of parties is virtually meaningless. We should note, however, that we view both the separation of powers and the separation of parties as having a double effect on presidential administrationboth motivating and checking presidentialism. Even absent divided government, American presidents are motivated to engage in presidential administration by the simple difficulty of the legislative process in Congress. Presidents who find themselves faced with hostile majorities in either or both Houses of Congress have that motivation enhanced. President Obama set up policies czars in the White House and revised OMB's approach to regulatory review well before he was faced with an intransigent Republican House of Representatives. When the GOP took the House, of course, President Obama abandoned his position that legislation was needed both to implement his immigration policies and to reorient environmental policy related to climate change. Levinson and Pildes are surely correct that separation of parties is a strong enhancement for Presidents to act on their presidentialist tendencies.

We believe the same is true with respect to the checking function of both separation of powers and separation of parties. When the unified government in President Obama's first two years managed to enact health insurance reform, the Affordable Care Act was, nevertheless, structured in a compromised form. The ACA depended for its success on subsequent willingness to appropriate subsidy funds and omitted the so-called "public option" that would have given the central government much more control over costs. And the individual mandate was backed by penalties that many observers believed inadequate to motivate compliance. Government was unified, but the president had to accept a less than optimal legislative design to see his signature domestic policy initiative enacted into law. The checking function on President Obama's policies escalated dramatically thereafter, which both prompted his independent presidential actions and stymied his legislative agenda. ${ }^{383}$

President Trump has found unified government particularly attractive in rolling back certain rules adopted late in the Obama Administration. And, of course, the checks related to the CRA run in both directions. Republican congresses under Obama passed five joint resolutions using the CRA, only to have them vetoed. ${ }^{384}$ President Trump, even with unified government, has not

383. This has not always been the case. In a number of eras of divided government presidents and congresses have cooperated to produce significant legislation. See BYRON E. SHAFER, THE AMERICAN POLITICAL PATTERN: STABILITY AND CHANGE, 1932-2016 (2016).

384. CAREY ET AL., supra note 334, at 5. 
attempted to push through major regulatory reform legislation in Congress, but has instead given marching orders to departmental and agency appointees. And, Congress' initial foray into budgeting during the Trump Administration failed to give the President funding for his much-vaunted wall.

Nor did Congress lay waste to the Environmental Protection Agency by enacting the Trump Administration's requested major funding cut. ${ }^{385}$ Moreover, whatever emerges from Congress and is signed by President Trump (if anything) is unlikely to reflect presidential rather than congressional preferences, where the two conflict. Indeed, the Tax Cuts and Jobs Act seems far more a function of congressional (rather than presidential) policymaking. As Professor Cane noted, even in unified government American Presidents do not have the legislative muscle of the British Prime Minister with a parliamentary majority. ${ }^{386}$

Checks, Balances, and the Role of the Judiciary. As mentioned earlier, the standard approach to judicial review of agency rulemaking reinforces congressional power, albeit the power of the enacting Congress, not necessarily the contemporaneous one. Courts have recently, to some degree, reinforced presidentialism through the rejection of double for-cause removal ${ }^{387}$ and forcause removal for the single-headed CFPB. ${ }^{388}$ But both with respect to DAPA and Trump's travel ban, the courts have shown themselves skeptical of aggressive presidentialism. The Texas $v$. United States Court not only recharacterized the DHS guideline on enforcement policy as a rule, but also opined that as a rule it would be substantively invalid. ${ }^{389}$ The Hawaii v. Trump and Washington $v$. Trump Courts acted, in innovative fashion, to remind the new President that his Executive Orders are cabined by constitutional restraints. ${ }^{390}$ Here again, overall regime structure-the existence of an independent judiciary-placed significant limits on presidential administration whether exercised through departmental guidance or by independent executive action.

We do not here take a position on whether these particular judicial rulings are appropriate responses to muscular presidentialism. We do believe, however, that recent experience has shown that Professor Kagan's call for more limited judicial review of agency action where policies have active presidential support is a bad idea. ${ }^{391}$ Presidentialism needs reasonable constraint to avoid excessive, unchecked executive action, given the one-way ratchet of power that recent experience seems to illustrate. The virtual unreviewability of executive enforcement and implementation discretion where that discretion is exercised to

385. Hulse, supra note 251.
$386 . \quad$ CANE, supra note 71, at 107.
$387 . \quad$ Free Enter. Fund v. Pub. Co. Accounting Oversight Bd., 561 U.S. 477 (2010).
$388 . \quad$ PHH Corp. v. CFPB, 839 F.3d 1 (D.C. Cir. 2016), vacated and remanded, 881
F.3d 75 (D.C. Cir. 2018) (en banc).
389. Texas v. United States, 809 F.3d 134, 171-76 (5th Cir. 2015), aff'd by an equally
divided court, 136 S. Ct. 2271 (2016).
390. Washington v. Trump, 847 F.3d 1151, 1161 (9th Cir. 2017); Hawai'i v. Trump,
241 F. Supp. 3d 1119 (D. Haw. 2017).
391. Kagan, supra note 21, at 2372-83.


withhold action is already a powerful limitation on the judiciary's checking functions. Moreover, Kagan's approach to judicial review exalts a one-time electoral majority (perhaps only in the Electoral College) as the sole touchstone of democratic legitimacy over the pluralist and deliberative processes of standard administrative action. And it would limit judicial review as a counterweight to presidentialism in the sense previously discussed - that is, as a re-enforcer of the supremacy of statutes and hence of the checking power of Congress.

The Role of Embedded Bureaucracy. Although it goes well beyond the scope of this Article, we should not leave this discussion without at least mentioning the potential role of career bureaucrats in checking or enhancing presidential administration. What we are calling "the embedded bureaucracy" is not formally a part of America's separation of powers constitutional structure. But, in some sense, the Roosevelt Administration's complaint about the "headless "fourth branch"" applies to executive departments and agencies, not just to independent commissions. We mentioned earlier the different experiences of the Obama and Trump Administrations in getting cooperation with their enforcement policies from an immigration bureaucracy that is enforcementoriented. Professional role matters. Government officials do not tend to join agencies with missions contrary to their own policy preferences or independent professional norms. Biological scientists at the Fish and Wildlife Service did not join that government agency because they think protecting wildlife is unimportant. Moreover, they have professional and scientific commitments to their discipline.

To the extent that a presidential administration attempts to promote policies that run counter to these agency mission and staff professional norm commitments, career bureaucrats are likely to be unenthusiastic, if not resistant. ${ }^{392}$ And anticipation of that lack of enthusiasm or resistance to some degree motivates presidential initiatives designed to take control of the bureaucracy, whether it be policy czars in the Obama White House or WhiteHouse-connected minders like those used unsuccessfully in the early Trump Administration. There is, perhaps, an important separation-of-powers role for this embedded bureaucracy to play-as a means to enforce congressional priorities (albeit those of past Congresses) through bureaucratic restraint on presidential administration. For this reason, we would question those recent judicial opinions that have invalidated bureaucratic structures that insulate administrators from at-will removal. These structures seem like valuable techniques for Congress to check presidential administration in its various forms. But an analysis of the relationship between presidents and inherited bureaucracies and administrative structures is a topic for another day. ${ }^{393}$

392. See Landler, supra note 363 ; Shear \& Lichtblau, supra note 363 ; Eilperin et al., supra note 363; Clement, supra note 329.

393. We also leave for another day a discussion of federalism's checking power. Cases like Texas v. United States and Massachusetts v. EPA highlight state uses of judicial review to thwart presidential direction of administration, but states and localities have significant enforcement roles under 
numerous federal programs (and their own independent policy authority in domains also subject to federal legislative and administrative action). As these words are written, California, itself the world's eighthlargest economy, seems headed toward decarbonization, and sanctuary cities are throwing some sand in the gears of ICE deportation efforts. 